\title{
Groundwater Availability of the Northern High Plains Aquifer in Colorado, Kansas, Nebraska, South Dakota, and Wyoming
}
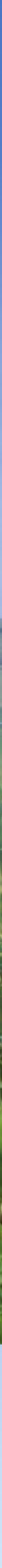
Cover. Upper illustration: Conceptual diagram showing average annual simulated water budget inflows and outflows by source and the amount of water in storage in the Northern High Plains aquifer for 2000-9. Example from figure 11B of this report.

Lower right illustration: Map showing distribution of precipitation for the Northern High Plains aquifer for the 2009 growing season. Example from figure $2 \mathrm{C}$ of this report.

Background photograph: Center-pivot irrigated cornfield near Ord, Nebraska, taken by J.P. Traylor, U.S. Geological Survey.

Back cover. Map of the conterminous United States showing the High Plains aquifer. 


\section{Groundwater Availability of the Northern High Plains Aquifer in Colorado, Kansas, Nebraska, South Dakota, and Wyoming}

By Steven M. Peterson, Jonathan P. Traylor, and Moussa Guira

Water Availability and Use Science Program

Professional Paper 1864 


\title{
U.S. Department of the Interior DAVID BERNHARDT, Secretary
}

\author{
U.S. Geological Survey \\ James F. Reilly II, Director
}

\section{U.S. Geological Survey, Reston, Virginia: 2020}

For more information on the USGS - the Federal source for science about the Earth, its natural and living resources, natural hazards, and the environment-visit https://www.usgs.gov or call 1-888-ASK-USGS.

For an overview of USGS information products, including maps, imagery, and publications, visit https://store.usgs.gov.

Any use of trade, firm, or product names is for descriptive purposes only and does not imply endorsement by the U.S. Government.

Although this information product, for the most part, is in the public domain, it also may contain copyrighted materials as noted in the text. Permission to reproduce copyrighted items must be secured from the copyright owner.

Suggested citation:

Peterson, S.M., Traylor, J.P., and Guira, M., 2020, Groundwater availability of the Northern High Plains aquifer in Colorado, Kansas, Nebraska, South Dakota, and Wyoming: U.S. Geological Survey Professional Paper 1864, 57 p., https://doi.org/10.3133/pp1864.

Associated data for this publication:

Peterson, S.M., Traylor, J.P., and Guira, M., 2020, MODFLOW-NWT groundwater flow model used to evaluate groundwater availability with five forecast scenarios in the Northern High Plains aquifer in Colorado, Kansas, Nebraska, South Dakota, and Wyoming: U.S. Geological Survey data release, https://doi.org/10.5066/P92UNY4F.

ISSN 1044-9612 (print)

ISSN 2330-7102 (online)

ISBN 978-1-4113-4361-0 


\section{Foreword}

Although often overlooked, groundwater is increasingly important to all our lives. Groundwater is the Nation's principal reserve of freshwater. It provides drinking water for half of the country, is essential to food production in the United States, and facilitates business and industrial activities. Groundwater also is an important source of water for sustaining the ecosystem health of rivers, wetlands, and estuaries throughout the country.

Groundwater-level declines resulting from large-scale development of groundwater resources, together with other effects of pumping, have led to concerns about the future availability of groundwater to meet our Nation's needs. The compounding effects of recent droughts underscore the need for an updated status of the Nation's groundwater resources. Assessments of groundwater resources provide the science and information needed by decision makers and the public to manage and use water resources responsibly. The potential future effects on groundwater resources from climate variability further exacerbate an already challenging situation, and the analysis of these potential effects adds to an already complex task.

The U.S. Geological Survey's Water Availability and Use Science Program is completing largescale multidisciplinary regional studies of groundwater availability, including the study of the Northern High Plains aquifer described herein. The regional studies are intended to inform citizens, communities, and natural resource managers of the condition of the Nation's groundwater resources and how changes in land use, water use, and climate have affected those resources. The studies also are aimed at developing tools to enable scientists and managers to forecast how these resources may change in the future. Information from these individual groundwater assessments of principal aquifer systems will be used to inform national assessment of water availability and will help answer questions about the Nation's ability to meet current and future demands for groundwater.

Donald Cline

Associate Director, U.S. Geological Survey

Water Resources Mission Area 



\section{Acknowledgments}

We acknowledge the World Climate Research Programme's Working Group on Coupled Modelling, which is responsible for the Coupled Model Intercomparison Project (CMIP), and we thank the climate modeling groups (Geophysical Fluid Dynamics Laboratory, and Japanese Meteorological Research Institute) for producing and making available their model output. For CMIP the U.S. Department of Energy's Program for Climate Model Diagnosis and Intercomparison provides coordinating support and led development of software infrastructure in partnership with the Global Organization for Earth System Science Portals.

This study was funded by the U.S. Geological Survey Water Availability and Use Science Program. The authors thank U.S. Geological Survey personnel John Masterson, Claudia Faunt, Howard Reeves, and Mike Fienen, whose suggestions and assistance directly contributed to this report and the work described therein. 



\section{Contents}

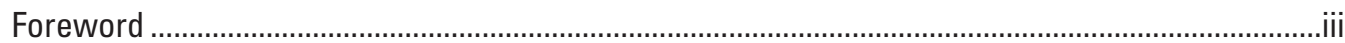

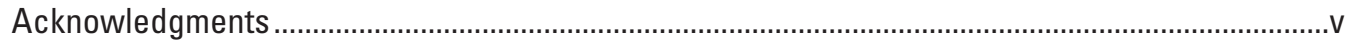

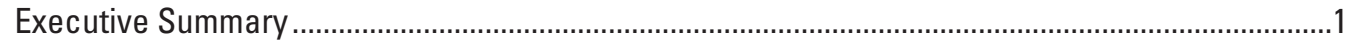

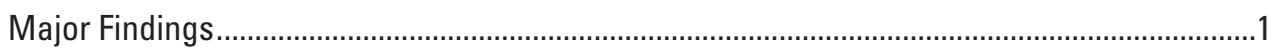

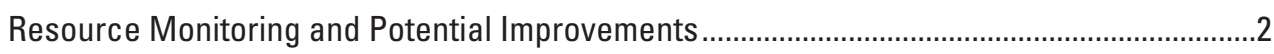

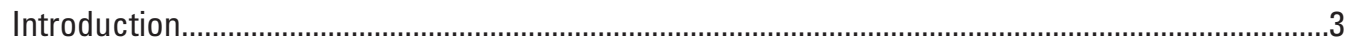

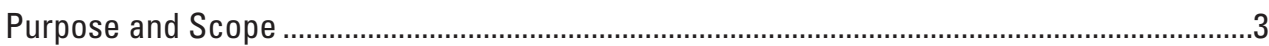

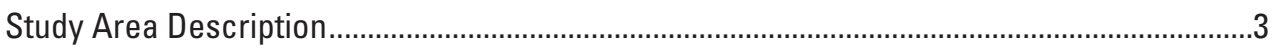

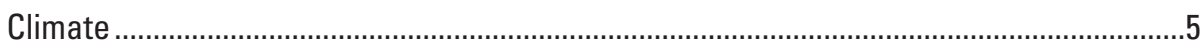

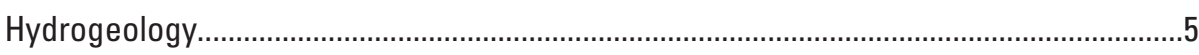

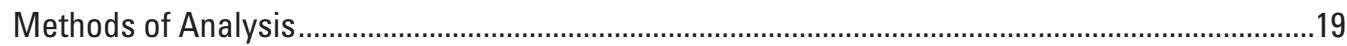

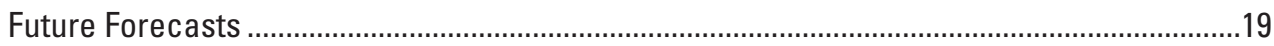

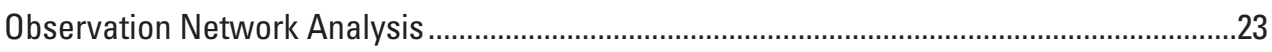

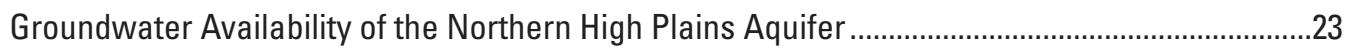

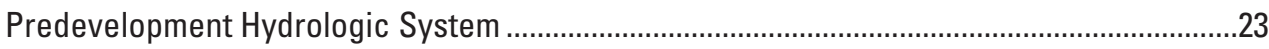

Description of the Predevelopment Hydrologic System ...............................................23

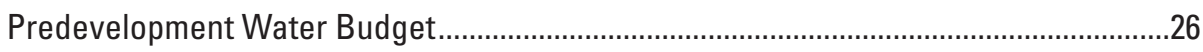

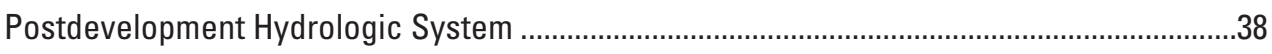

Postdevelopment Water Budgets and Changes from Predevelopment..........................38

Response of the Hydrologic System to Estimated Future Conditions .......................................39

Data Used to Forecast Future Conditions ..................................................................

Soil-Water-Balance Model ...................................................................................

Baseline Soil-Water-Balance Model......................................................................39

Alternative Land Cover Soil-Water-Balance Models ..............................................39

Alternative Climate Soil-Water-Balance Models ....................................................42

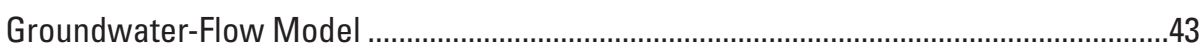

Baseline Forecast................................................................................................

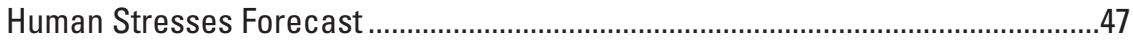

Environmental Stresses Forecast ......................................................................

Resource Monitoring and Potential Improvements ..............................................................51

Importance of Continuing Ongoing Data Collection Program .........................................51

Potential New Groundwater-Level Monitoring Locations .............................................51

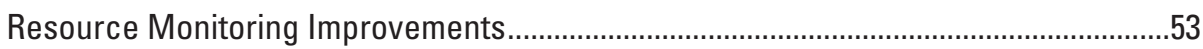

Challenges for Evaluation of Groundwater Availability.....................................................53

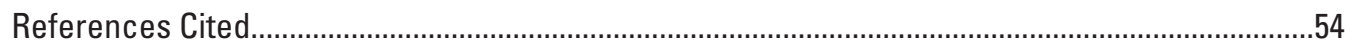




\section{Figures}

1. Map showing the Northern High Plains aquifer extent, study area, major river basins, U.S. Geological Survey streamgage locations, and weather stations used in analyses.

2. Maps showing the distribution of precipitation for the Northern High Plains aquifer .....6

3. Maps showing the distribution of potential evapotranspiration for the Northern High Plains aquifer

4. Maps showing the distribution of potential evapotranspiration minus precipitation for the Northern High Plains aquifer.....

5. Map showing locations of nonirrigated, groundwater-irrigated, and surface-water-irrigated lands in 2008 for the Northern High Plains aquifer, Colorado, Kansas, Nebraska, South Dakota, and Wyoming

6. Map showing hydrogeologic units and aquifer base of the Northern High Plains aquifer.

7. Maps showing the Northern High Plains aquifer, 2000-9.

8. Map showing locations where groundwater levels measured from May 2008 to April 2009 were used to calibrate the Northern High Plains aquifer groundwater model

9. Map showing locations across the Northern High Plains aquifer where potential new water-level observations were subjected to network analysis to indicate the usefulness for future groundwater availability monitoring.

10. Graph showing Nebraska registered irrigation wells and irrigated land for the Northern High Plains aquifer groundwater model, 1940-2009

11. Conceptual diagrams comparing average annual simulated water budget inflows and outflows by source and the amount of water in storage in the Northern High Plains aquifer.

12. Graph showing net release from and net replenishment to groundwater in storage of the Northern High Plains aquifer for 1900-2009 and trends of change in storage for five forecasts representing 2009-49.

13. Maps and graphs showing major river basins and corresponding simulated water budget inflows and outflows of the Northern High Plains aquifer

14. Graphs showing average simulated 2000-9 base flow, and average 2040-49 simulated base flow, for the baseline, GFDL, MRI, A2LC, and B2LC forecasts

15. Map showing standard deviation of simulated groundwater levels at selected locations across five alternate $2009-49$ forecasts.

\section{Tables}

1. Summary of growing season (May 1-September 30) precipitation, potential evapotranspiration, and precipitation minus potential evapotranspiration, 2000-9, Northern High Plains aquifer

2. Generalized section of geologic units of the Northern High Plains aquifer

3. Summary of simulated average annual groundwater budgets for $1940-49$ and 2000-9, simulated by the Northern High Plains aquifer groundwater-flow model in Colorado, Kansas, Nebraska, South Dakota, and Wyoming ...

4. Summary of 2000-9 average annual precipitation and difference from 1940 to 2009 average annual precipitation for selected weather stations in the Northern High Plains aquifer. 
5. Summary of land cover classification for the Northern High Plains aquifer Soil-Water-Balance (SWB) model for 2009 and 2049, for SWB models

corresponding to the baseline, A2LC, and B2LC forecasts. ...

6. Summary of downscaled global climate model precipitation and temperature data used as inputs for the Northern High Plains aquifer Soil-Water-Balance model for 2009-49 for the baseline, GFDL, and MRI forecasts, compared with 2000-9 average measured data, and summary of corresponding output evapotranspiration, recharge, and irrigation requirements.

7. Summary of average annual simulated groundwater budgets for 2009-49 for the Northern High Plains aquifer, and 2049 groundwater in storage, for the baseline, A2LC, B2LC, GFDL, and MRI forecasts and differences from the baseline for the A2LC, B2LC, GFDL, and MRI forecasts.

\section{Conversion Factors}

U.S. customary units to International System of Units

\begin{tabular}{|c|c|c|}
\hline Multiply & By & To obtain \\
\hline \multicolumn{3}{|c|}{ Length } \\
\hline inch (in.) & 2.54 & centimeter $(\mathrm{cm})$ \\
\hline inch (in.) & 25.4 & millimeter (mm) \\
\hline foot $(\mathrm{ft})$ & 0.3048 & meter (m) \\
\hline mile (mi) & 1.609 & kilometer (km) \\
\hline \multicolumn{3}{|c|}{ Area } \\
\hline acre & 4,047 & square meter $\left(\mathrm{m}^{2}\right)$ \\
\hline acre & 0.4047 & hectare (ha) \\
\hline acre & 0.4047 & square hectometer $\left(\mathrm{hm}^{2}\right)$ \\
\hline acre & 0.004047 & square kilometer $\left(\mathrm{km}^{2}\right)$ \\
\hline square foot $\left(\mathrm{ft}^{2}\right)$ & 929.0 & square centimeter $\left(\mathrm{cm}^{2}\right)$ \\
\hline square foot $\left(\mathrm{ft}^{2}\right)$ & 0.09290 & square meter $\left(\mathrm{m}^{2}\right)$ \\
\hline square mile $\left(\mathrm{mi}^{2}\right)$ & 259.0 & hectare (ha) \\
\hline square mile $\left(\mathrm{mi}^{2}\right)$ & 2.590 & square kilometer $\left(\mathrm{km}^{2}\right)$ \\
\hline \multicolumn{3}{|c|}{ Volume } \\
\hline cubic foot $\left(\mathrm{ft}^{3}\right)$ & 28.32 & cubic decimeter $\left(\mathrm{dm}^{3}\right)$ \\
\hline cubic foot $\left(\mathrm{ft}^{3}\right)$ & 0.02832 & cubic meter $\left(\mathrm{m}^{3}\right)$ \\
\hline acre-foot (acre-ft) & 1,233 & cubic meter $\left(\mathrm{m}^{3}\right)$ \\
\hline acre-foot (acre-ft) & 0.001233 & cubic hectometer $\left(\mathrm{hm}^{3}\right)$ \\
\hline \multicolumn{3}{|c|}{ Flow rate } \\
\hline acre-foot per year (acre-ft/yr) & 1,233 & cubic meter per year $\left(\mathrm{m}^{3} / \mathrm{yr}\right)$ \\
\hline acre-foot per year (acre-ft/yr) & 0.001233 & cubic hectometer per year $\left(\mathrm{hm}^{3} / \mathrm{yr}\right)$ \\
\hline cubic foot per second $\left(\mathrm{ft}^{3} / \mathrm{s}\right)$ & 0.02832 & cubic meter per second $\left(\mathrm{m}^{3} / \mathrm{s}\right)$ \\
\hline inch per year (in/yr) & 25.4 & millimeter per year (mm/yr) \\
\hline \multicolumn{3}{|c|}{ Hydraulic gradient } \\
\hline foot per mile (ft/mi) & 0.1894 & meter per kilometer $(\mathrm{m} / \mathrm{km})$ \\
\hline
\end{tabular}

Temperature in degrees Fahrenheit $\left({ }^{\circ} \mathrm{F}\right)$ may be converted to degrees Celsius $\left({ }^{\circ} \mathrm{C}\right)$ as follows:

$$
{ }^{\circ} \mathrm{C}=\left({ }^{\circ} \mathrm{F}-32\right) / 1.8 \text {. }
$$




\section{Datum}

Vertical coordinate information is referenced to the North American Vertical Datum of 1988 (NAVD 88).

Horizontal coordinate information is referenced to the North American Datum of 1983 (NAD 83).

Elevation, as used in this report, refers to distance above the vertical datum.

\section{Abbreviations}

\begin{tabular}{|c|c|}
\hline A2LC & forecast using A2 land cover and 2004 climate data \\
\hline B2LC & forecast using B2 land cover and 2004 climate data \\
\hline CMIP5 & Coupled Model Intercomparison Project phase 5 \\
\hline ESM & Earth System Modelling \\
\hline GCM & General Circulation Model \\
\hline GFDL & $\begin{array}{l}\text { forecast using } 2009 \text { land cover and Geophysical Fluid Dynamics Laboratory } \\
\text { Earth System Model Second Generation downscaled daily outputs }\end{array}$ \\
\hline MODFLOW-NWT & $\begin{array}{l}\text { Newton formulation of the U.S. Geological Survey's modular finite- } \\
\text { difference groundwater-flow model }\end{array}$ \\
\hline MRI & $\begin{array}{l}\text { forecast using } 2009 \text { land cover and Japanese Meteorological Research } \\
\text { Institute Coupled Global Climate Model Version } 3 \text { downscaled daily outputs }\end{array}$ \\
\hline PET & potential evapotranspiration \\
\hline $\mathrm{RCP}$ & Representative Concentration Pathway \\
\hline SWB & Soil-Water-Balance \\
\hline USGS & U.S. Geological Survey \\
\hline
\end{tabular}




\title{
Ground water Availability of the Northern High Plains Aquifer in Colorado, Kansas, Nebraska, South Dakota, and Wyoming
}

\author{
By Steven M. Peterson, Jonathan P. Traylor, and Moussa Guira
}

\section{Executive Summary}

The Northern High Plains aquifer underlies about 93,000 square miles of Colorado, Kansas, Nebraska, South Dakota, and Wyoming and is the largest subregion of the nationally important High Plains aquifer. Irrigation, primarily using groundwater, has supported agricultural production since before 1940, resulting in nearly \$50 billion in sales in 2012 . In 2010, the High Plains aquifer had the largest groundwater withdrawals of any major aquifer system in the United States. Nearly one-half of those withdrawals were from the Northern High Plains aquifer, which has little hydrologic interaction with parts of the aquifer farther south. Land-surface elevation ranges from more than 7,400 feet (ft) near the western edge to less than 1,100 ft near the eastern edge. Major streams primarily flow west to east and include the Big Blue River, Elkhorn River, Loup River, Niobrara River, Republican River, and Platte River with its two forks - the North Platte River and South Platte River. Population in the Northern High Plains aquifer area is sparse with only 2 cities having a population greater than 30,000 .

Droughts across much of the area from 2001 to 2007, combined with recent (2004-18) legislation, have heightened concerns regarding future groundwater availability and highlighted the need for science-based water-resource management. Groundwater models with the capability to provide forecasts of groundwater availability and related stream base flows from the Northern High Plains aquifer were published recently (2016) and were used to analyze groundwater availability. Stream base flows are generally the dominant component of total streamflow in the Northern High Plains aquifer, and total streamflows or shortages thereof define conjunctive management triggers, at least in Nebraska. Groundwater availability was evaluated through comparison of aquifer-scale water budgets compared for periods before and after major groundwater development and across selected future forecasts. Groundwater-level declines and the forecast amount of groundwater in storage in the aquifer also were examined.

\section{Major Findings}

Major findings informing groundwater availability of the Northern High Plains aquifer include the following:

- Aquifer losses to irrigation withdrawals increased greatly from 1940 to 2009 and were the largest average 2000-9 outflow (49 percent of total). Groundwater levels generally were rising from 1940 to 1949 , but the increase in losses to wells, combined with climatic differences between 1940-49 and 2000-9, resulted in groundwater-level declines from 2000 to 2009 . Average 2000-9 groundwater in storage was 2,428 million acre-feet (acre-ft), or about 28 million acre-ft less than for 1940-49.

- Basin to basin groundwater flows were not a large part of basin water budgets. This means that the dominant processes affecting water budgets happened within the basins, not as groundwater flows to or from other basins.

- Development of irrigated land and associated withdrawals were not uniform across the Northern High Plains aquifer, and different parts of the Northern High Plains aquifer responded differently to agricultural development. For the Big Blue and Republican River Basins, 2000-9 aquifer losses to irrigation wells were larger than all other gains and losses for either 1940-49 or 2000-9. The 2000-9 Republican River Basin water-level declines were nearly one-half of the declines of the Northern High Plains aquifer, thought to be primarily caused by the large losses to irrigation wells, resulting from a deficit between precipitation and potential evapotranspiration. For other stream basins containing fewer irrigated lands, such as the Loup and Niobrara River Basins, the largest aquifer outflows were to streams, sustaining base flow. 
- For the Northern High Plains aquifer, areas with high recharge and low evapotranspiration had the most streamflow, and most streams only remove water from the aquifer. In some other principal aquifers, such as the Mississippi Alluvial Plain, streams provide an important source of recharge to the aquifer.

- Results of a baseline future forecast indicated that groundwater levels declined overall, indicating an overdraft of the aquifer when climate was about average and agricultural development was held at the same state as 2009. However, forecasted 2009-49 declines (at a rate of 1.6 million acre-feet per year [acre-ft/yr]) were at less than one-half the rate than that of 2000-9, a drier than average period and, therefore, indicated that by 2049, the amount of groundwater in storage in the aquifer would be 2,372 million acre-ft, or 56 million acre-ft less than the 2000-9 average.

- Results of two human stresses future forecasts indicated that increases of 13 percent or 23 percent in agricultural development, mostly near areas of previous development, caused increases in groundwater pumping of 8 percent or 11 percent, and resulted in continued groundwater-level declines, at rates 0.3 or 0.5 million acre- $\mathrm{ft} / \mathrm{yr}$ larger than the baseline forecast. However, both forecasts caused about the same decrease in stream base flow of 100,000 acre-ft/yr.

- Results of environmental stresses forecasts (generated from two downscalings of global climate model outputs) compared with the baseline forecast indicated that even though annual precipitation was nearly the same, differences in temperature and a redistribution of precipitation from the spring to the growing season (from about May 1 through September 30), created a large (12-15 percent) decrease in recharge to the aquifer.

- For the two environmental stresses forecasts, temperature and precipitation were distributed about the same among basins of the Northern High Plains aquifer, but the amounts were different. The largest effects of these forecasts were in two basins: a northern basin that had not had previous groundwater-level declines and a southern basin where groundwater levels have declined previously. In the baseline forecast, the largest outflow of the northern basin had been to streams, and the decreased recharge created a 15-percent decline in that flow; however, in the southern basin, which had had far less base flow in the baseline forecast, base flow declined by a larger part (35 percent).

\section{Resource Monitoring and Potential Improvements}

The importance of resource monitoring and potential improvements is summarized below:

- Streamflow and groundwater-level data provide fundamental data describing water availability and will continue to be primary sources of information on the health of the aquifer (as well as model calibration data) and, therefore, are critical to the success of future groundwater availability forecasts. Collection of additional such data at more locations, or at higher temporal frequency, may further reduce water availability uncertainty and model uncertainty.

- Additional geologic data, collected through test hole drilling, airborne resistivity, or other methods, could aid in improving future models. Aquifer property data directly affect simulations of groundwater flow and related uncertainty; the collection of additional geologic data describing aquifer thickness and other properties would likely directly benefit future groundwater models and studies. Previous work has indicated that the addition of such data reduced simulation uncertainty.

- The simulation described in this report also can be used as a tool to evaluate the benefit of collecting additional physical or hydrologic data. As an example, an analysis to evaluate where the collection of additional groundwater-level data would provide the most benefit across select candidate locations was completed using the simulation. These results indicated that the largest variations were spatially biased, generally along the drainage divide between the South Platte River and the Republican River Basin in southwest Nebraska, close to the northeast corner of Colorado. Other locations with large variations were commonly closer to drainage divides between simulated streams in the area and near the downstream end of the South, Middle, and North Loup Rivers.

- Groundwater withdrawals for irrigation have the single largest anthropogenic effect on the groundwater-flow system of the Northern High Plains aquifer and are the largest outflow component of the groundwater system, yet one that is poorly defined by data. Therefore, additional groundwater withdrawal data would likely improve model calibration and reduce uncertainty. By 2016, groundwater withdrawal meters had been installed in more locations across the area, yet it is 
unclear if enough data have been collected to describe aquifer-scale groundwater withdrawals, or if data have been collected over a sufficient period. In addition to the groundwater withdrawal data, ancillary related data, such as irrigation application methods and crops grown at each groundwater withdrawal site, would provide needed context to improve estimated groundwater withdrawals.

In general, although the model is considered accurate at a regional scale, it is not suitable for evaluating local-scale problems nor for short periods of less than a few months. Readers who are interested in more local-scale analysis could use data and results of this study as a starting point for further refinement. Readers are cautioned that future forecast base flows and groundwater budgets included in the analysis described in this report are not comprehensive and may not be the average nor span the range of effects caused by potential future climate or land cover changes. These forecasts are provided as examples of how the groundwater-flow model can be used as a tool to evaluate aquifer and stream base flow responses to potential future conditions.

\section{Introduction}

The High Plains aquifer (fig. 1) is a nationally important water resource underlying about 175,000 square miles $\left(\mathrm{mi}^{2}\right)$ in parts of eight States: Colorado, Kansas, Nebraska, New Mexico, Oklahoma, South Dakota, Texas, and Wyoming (Qi, 2010). Irrigation, primarily using groundwater, has supported agricultural production since before 1940, resulting in nearly $\$ 50$ billion in sales in 2012 (U.S. Department of Agriculture, 2019). In 2010, the High Plains aquifer had the largest groundwater withdrawals of any major aquifer system in the United States (15.1 million acre-feet [acre-ft]; Maupin and others, 2014). At the onset of this study (2008), team members and program coordinators identified that it would be beyond scope to study all parts of the aquifer in detail and determined that the most value would be added by focusing on the Northern High Plains aquifer.

The Northern High Plains aquifer (labeled "study area" on fig. 1) is a distinct region that has little hydrologic interaction with parts of the aquifer farther south and is the largest subregion of the aquifer. In 2010, groundwater withdrawals from the Northern High Plains aquifer were about 42 percent of the total groundwater withdrawals from the High Plains aquifer (Maupin and others, 2014). In 2010, groundwater withdrawals for irrigation, public supply, livestock, and other purposes were 95, 2, 2, and 1 percent, respectively, of the groundwater withdrawals from the Northern High Plains aquifer (Maupin and others, 2014). In 2008, about 8,379,000 acres $\left(13,092 \mathrm{mi}^{2}\right.$ or 13 percent of the area) of the Northern High Plains aquifer were developed for agriculture with irrigation (U.S. Department of Agriculture, 2019); of that area, about
11 percent was served by surface-water diversions and the remainder was irrigated with groundwater. Droughts across much of the area from 2001 to 2007, combined with recent legislation (Nebraska Department of Natural Resources, 2004), have heightened concerns regarding future groundwater availability and highlighted the need for additional information to support science-based water-resource management. For example, although surface-water development is managed at the State level and groundwater is managed at a regional level in Nebraska, shortages of surface water can trigger integrated management of surface water and groundwater (Nebraska Department of Natural Resources, 2004). Groundwater models with the capability to provide forecasts of groundwater availability and related stream base flows from the Northern High Plains aquifer were recently published (Peterson and others, 2016a). Using a groundwater-flow model of the Northern High Plains aquifer, future groundwater availability for various potential future conditions can be simulated and can provide information about the effects of potential future changes in climate or land cover on the aquifer and related groundwater discharge and how simulated groundwater budgets differ for subregions.

\section{Purpose and Scope}

This report documents the analysis of groundwater availability for the Northern High Plains aquifer using a calibrated model that simulates from presettlement to April 30, 2009 (Peterson and others, 2016a), and a select set of 2009-49 forecast conditions. The report describes the methods of analysis and the models used as tools for the analysis that can be revised to evaluate water availability under other potential future conditions. For the included forecasts, the report also describes aquifer-scale groundwater budgets and the amount of groundwater in the aquifer, basin-scale groundwater budgets, simulated base flows of major streams, and aspects related to hydrologic monitoring.

\section{Study Area Description}

Information on the study area presented in this section is from Peterson and others (2016a) unless cited otherwise. The Northern High Plains aquifer (study area, fig. 1) underlies about 62 million acres of the States of Colorado, Kansas, Nebraska, South Dakota, and Wyoming. Land-surface elevation ranges from more than 7,400 feet (ft) near the western edge to less than $1,100 \mathrm{ft}$ near the eastern edge. Major streams primarily flow west to east and include the Big Blue River, Elkhorn River, Loup River, Niobrara River, Republican River, and Platte River with its two forks - the North Platte River and South Platte River (fig. 1). Population in the study area is sparse with only 2 cities having a population greater than 30,000 (Cheyenne, Wyoming, and Grand Island, Nebraska; U.S. Geological Survey, 2004). 


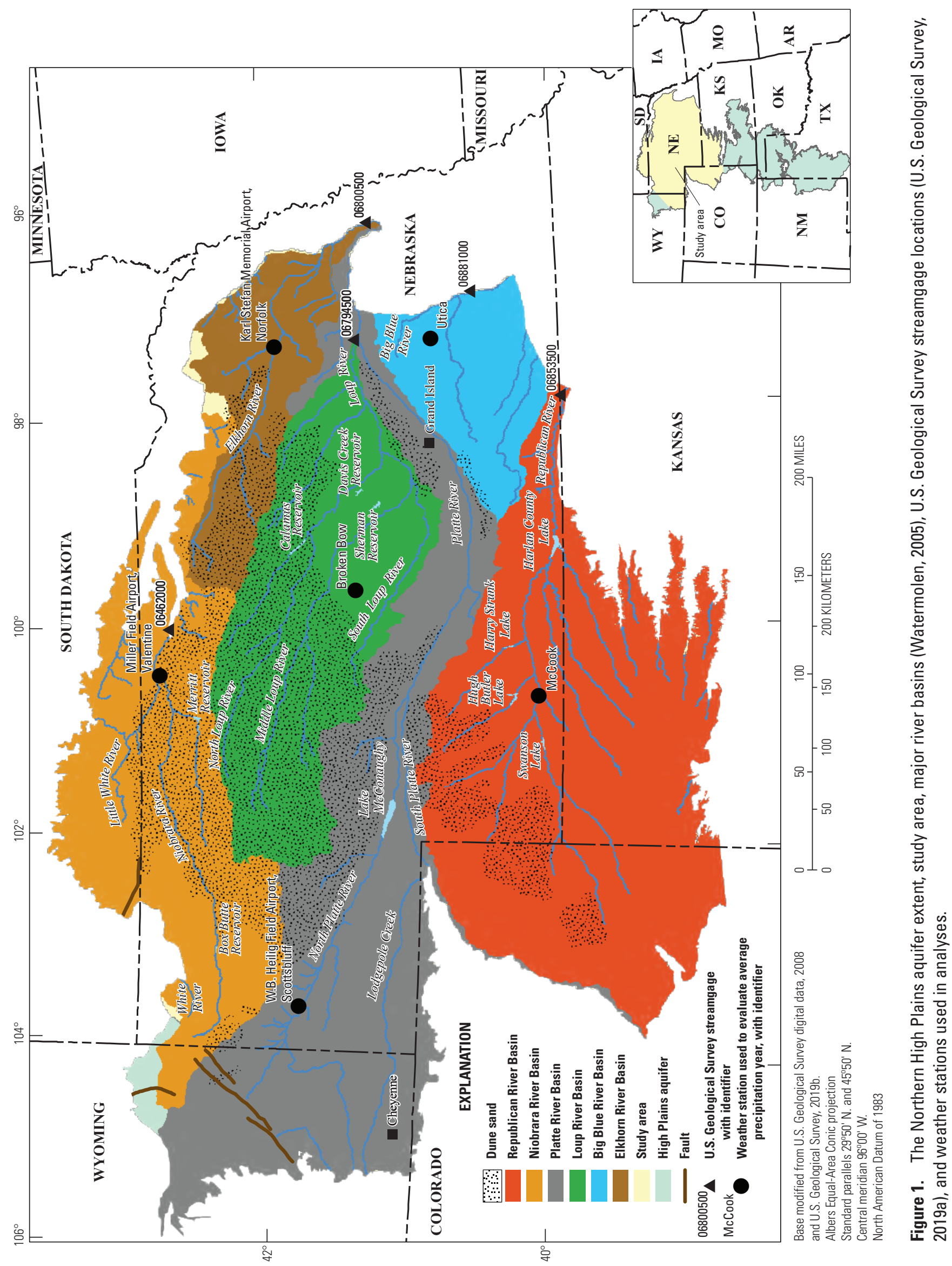




\section{Climate}

Precipitation generally increases west to east and ranges from less than 12 inches (in.) in the western part of the Northern High Plains aquifer to almost 31 in. in the eastern part (Peterson and others, 2016a; fig. 2A). The average annual precipitation from 2000 to 2009 was $21.1 \mathrm{in}$. More than one-half of the precipitation falls during the growing season, or from about May 1 through September 30; for example, average annual 2000-9 Northern High Plains aquifer growing season precipitation ranged from 8.8 (2002) to 15.7 in. (2009), with an average of $13.1 \mathrm{in}$. (table 1). The general distribution of precipitation in the growing season is the same as for annual or decadal periods, but some subregional variations exist; for example, in 2002, growing season precipitation on the Nebraska side of the north-east corner of Colorado was more than 16 in., around twice that of the surrounding region where it was about 6-10 in. (fig. 2B). In 2009, growing season precipitation was more than 14 in. for most of the central Northern High Plains aquifer but was atypically less in the lower Republican River Basin and Big Blue River Basin, in the southeast part of the area (fig. 2C).

Average annual (1981-2010) temperatures generally are highest in the southern part of the Northern High Plains aquifer (Trego County, Kansas, average of 54 degrees Fahrenheit [ $\left.{ }^{\circ} \mathrm{F}\right]$; High Plains Regional Climate Center, 2015) and decrease to the north (Jackson County, South Dakota, average of $47^{\circ} \mathrm{F}$ ) and with increasing elevation near the western edge (Laramie County, Wyo.; average of $45^{\circ} \mathrm{F}$ ). Higher temperature directly relates to higher potential evapotranspiration (PET), so the largest PET rates were in the southern and western parts of the area, at more than 51 inches per year (in/yr), except at the highest elevation area in Wyoming (fig. 3). The smallest PET rates were in the northeastern part of the area, at around $41 \mathrm{in} / \mathrm{yr}$, and the 2000-9 average annual PET rate was $45.8 \mathrm{in} / \mathrm{yr}$. As with precipitation, annual PET rates follow the decadal regional distribution and PET rates are highest during the growing season (May 1-September 30). However, some annual variations exist; for example, although average PET rates for the growing season of 2002 (32.6 in.) and 2009 (30 in.) were fairly similar (table 1 ), in 2002, the western onehalf of the area had a PET rate of more than 32 in., whereas for 2009, only part of western Nebraska and the upper end of the Republican River Basin exceeded 32 in. (fig. 3B, C).

Average annual 2000-9 PET exceeded precipitation by about $10 \mathrm{in}$. for the eastern part of the area and by more than 36 in. for the western part of the area (fig. $4 A$ ). This means that, on average for 2000-9, all precipitation would have been consumed by PET annually. PET also exceeded precipitation for every 2000-9 growing season (table 1), with the average deficit within the range from 14.3 in. (2009) to $23.8 \mathrm{in.} \mathrm{(2002).}$ The distribution of the deficit was different for different years; for example, for the 2002 growing season, the deficit was larger than $18 \mathrm{in}$. except in the eastern part of the area, whereas for the 2009 growing season, only the northwestern part of the area had a deficit exceeding 18 in. (fig. $4 B, C$ ).
The economy of lands overlying the Northern High Plains aquifer depends on agriculture, and irrigation has sustained agricultural production for parts of the area and years where precipitation was less than crops needed. Hence the area of irrigated land has increased from about 1890 until at least 2015. Early (circa 1890) irrigation was through the diversion of surface water (State Board of Irrigation, 1899), and most surface-water irrigation projects, covering 1.7 percent of the area or 13 percent of irrigated land in the study area, were substantially in place by 1955 . Development of groundwater was meager before 1940 (Weeks and others, 1988), covering less than 0.5 percent of the study area. By 1949, about 827,000 acres of the Northern High Plains aquifer were irrigated (1.7 percent of the area), expanding primarily through groundwater development to $8,379,000$ acres by 2008 (U.S. Department of Agriculture, 2019). In 2008, most of the $1,085,000$ acres irrigated with surface water used diversions from the Platte River system or reservoirs therein (fig. 1), whereas 7,294,000 acres of groundwater-irrigated areas (11.7 percent of the area) were most intensive in the eastern one-half of the Northern High Plains aquifer (fig. 5). Additional information on land cover data and changes through time are available in Houston and others (2013) and Peterson and others (2016b).

\section{Hydrogeology}

Information on the study area presented in this section is from Peterson and others (2016a) unless cited otherwise. The general hydrogeology of the High Plains aquifer was described in Gutentag and others (1984); a summary of that description is provided herein as a convenience to the reader. The High Plains aquifer consists of hydraulically connected deposits of late Tertiary and Quaternary age (fig. 6, table 2; Gutentag and others, 1984). Late Tertiary-age deposits, from oldest to youngest, include the Chadron Formation of the White River Group (Bartos and others, 2014), Brule Formation of the White River Group, Arikaree Group, Ogallala Formation, and Broadwater Formation (Gutentag and others, 1984; Diffendal, 1995, Diffendal and others, 2008). Quaternary-age deposits include alluvial, valley-fill, dune sand, and glacial deposits (fig. 6). The Ogallala Formation composes most of the Northern High Plains aquifer (fig. 6, table 2; Gutentag and others, 1984). Generally, low-permeability geologic units of midTertiary age or older underlie the High Plains aquifer (Weeks and Gutentag, 1981), forming a gently eastwardly dipping (5-7 feet per mile) paleosurface where the High Plains aquifer units were deposited (fig. 6; Peterson and Traylor, 2016). Local variations in paleosurface elevation form buried valleys. Groundwater flow between the High Plains aquifer and the underlying units is minimal. Groundwater flow in the Northern High Plains aquifer corresponds to the aquifer base slope and flows from west to east, except where it discharges to streams or is removed by evapotranspiration.

The Chadron and Brule Formations of the White River Group, together with the younger Arikaree Group, are 


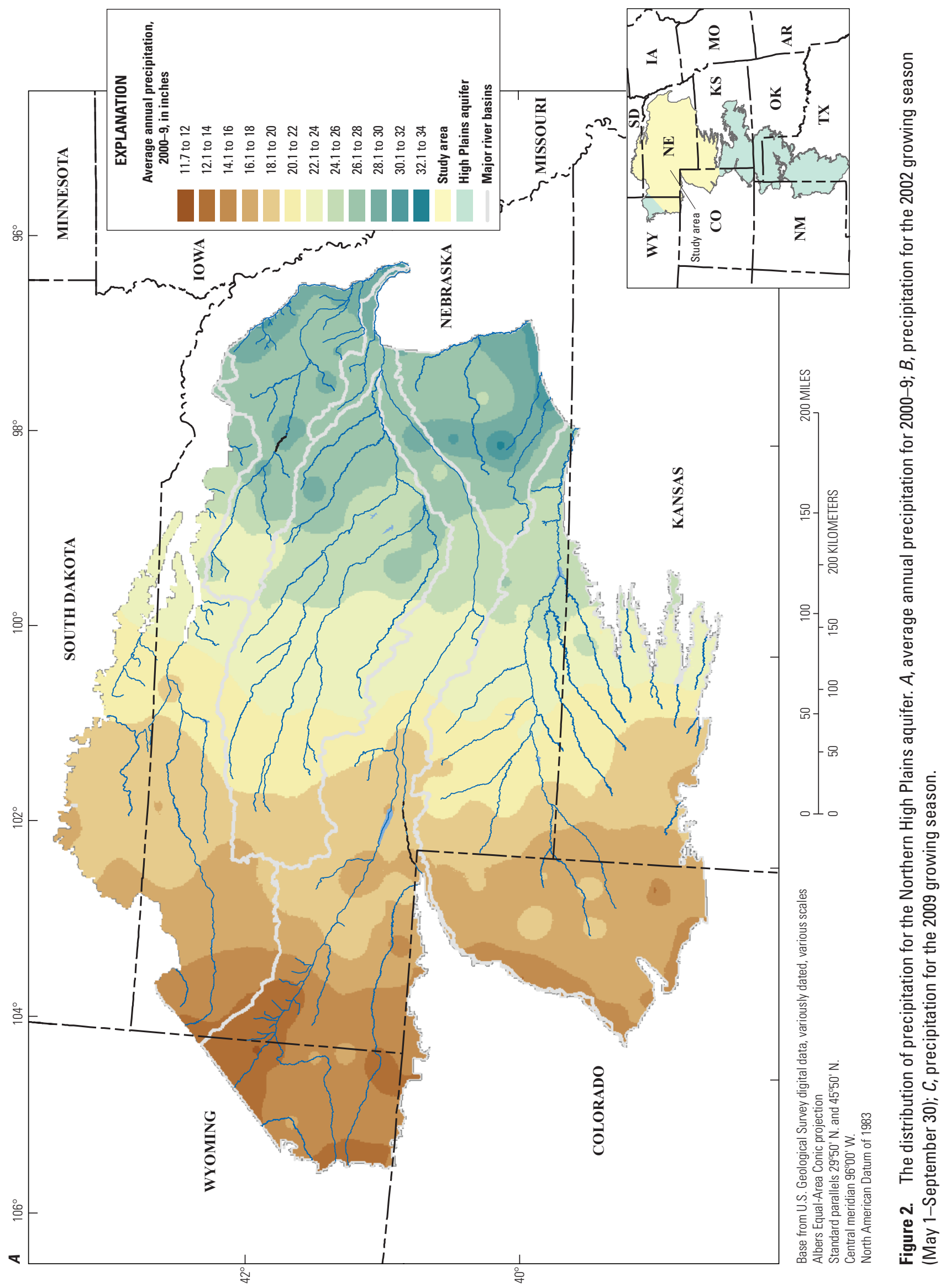




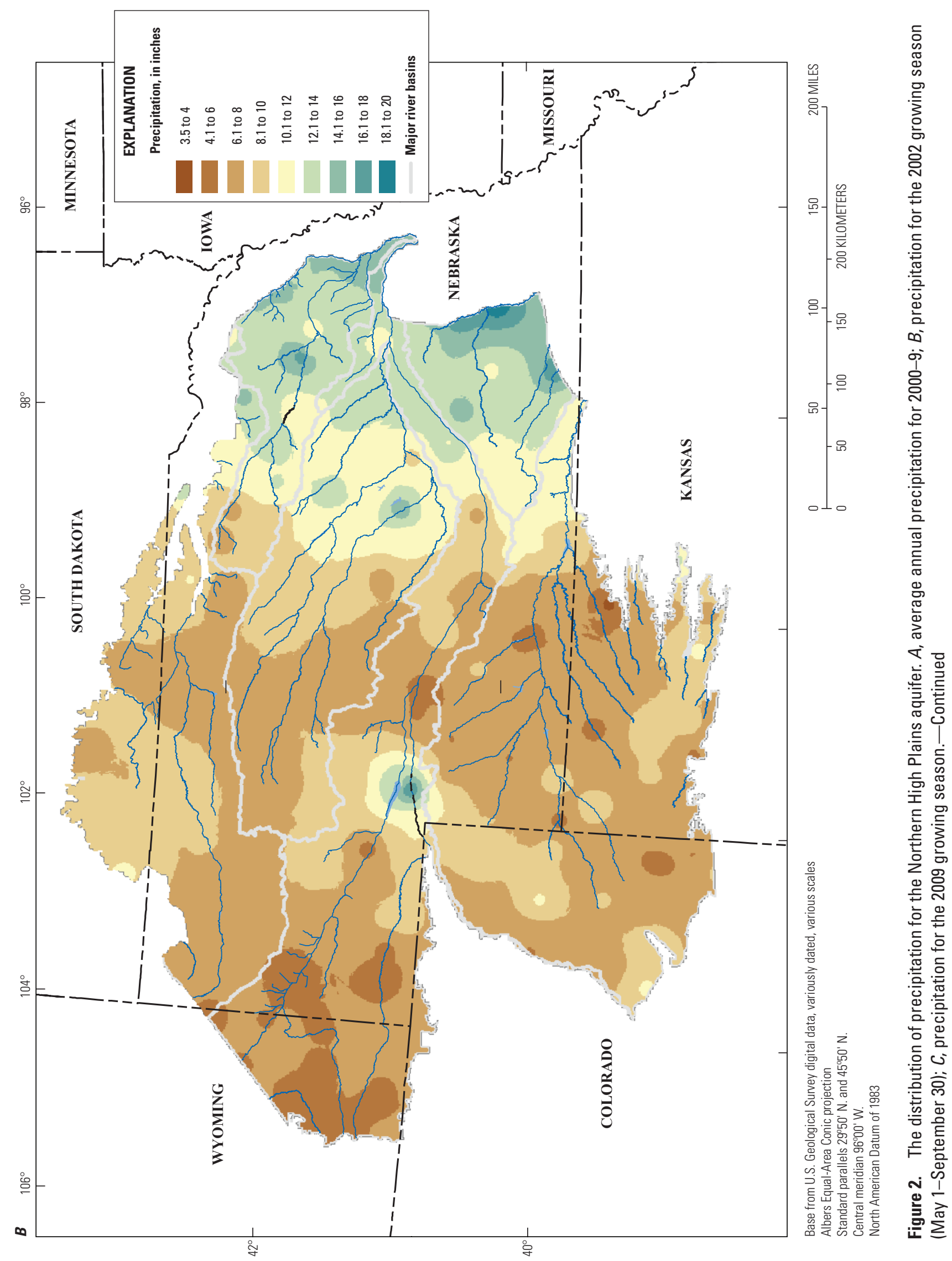




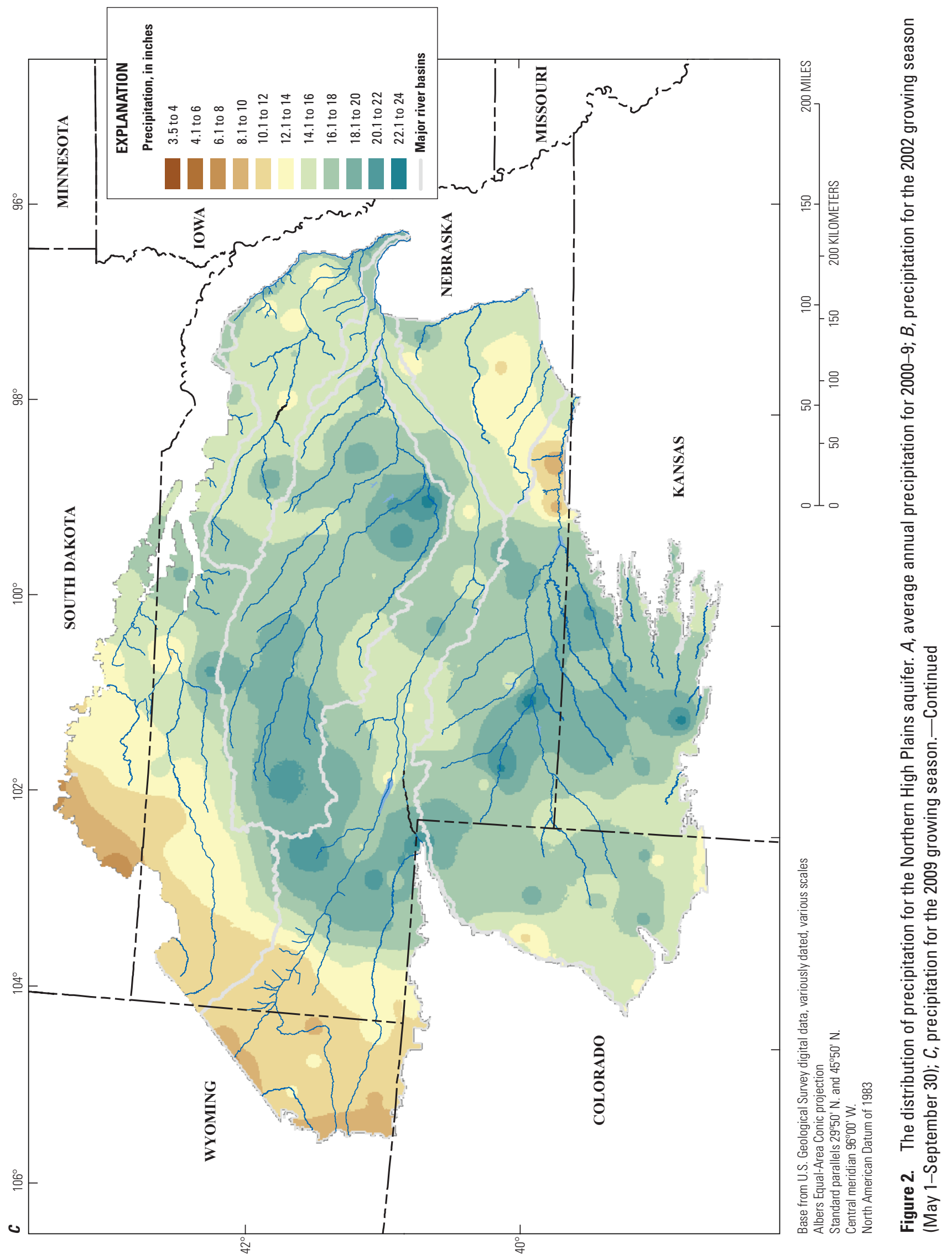


Table 1. Summary of growing season (May 1-September 30) precipitation, potential evapotranspiration, and precipitation minus potential evapotranspiration, 2000-9, Northern High Plains aquifer (Peterson and others, 2016b).

PPT, precipitation; PET, potential evapotranspiration]

\begin{tabular}{cccc}
\hline \multirow{2}{*}{ Year } & \multicolumn{3}{c}{ Growing season (May 1-September 30) } \\
\cline { 2 - 4 } & PPT, in inches & PET, in inches & PPT minus PET, in inches \\
\hline 2000 & 10.1 & 32.8 & -22.7 \\
2001 & 13.6 & 31.6 & -18.0 \\
2002 & 8.8 & 32.6 & -23.8 \\
2003 & 11.1 & 31.6 & -20.5 \\
2004 & 14.1 & 30.6 & -16.5 \\
2005 & 14 & 31.8 & -17.8 \\
2006 & 12.1 & 32.3 & -20.2 \\
2007 & 14.7 & 31.5 & -16.8 \\
2008 & 16.4 & 30.9 & -14.5 \\
2009 & 15.7 & 30.0 & -14.3 \\
Average & $\mathbf{1 3 . 1}$ & $\mathbf{3 1 . 6}$ & $-\mathbf{1 8 . 5}$ \\
\hline
\end{tabular}

generally fine-grained, low-permeability units except for a few areas of high permeability and areas where permeability has been increased by fractures. These are the oldest geologic units of the High Plains aquifer and are along the northwestern margins of the Northern High Plains aquifer (fig. 6, table 2). The Brule Formation is considered part of the High Plains aquifer only where the permeability has been increased by secondary porosity such as joints, fractures, and solution openings (Gutentag and others, 1984). Where it has not been enhanced through secondary porosity, the top of the Brule Formation forms the base of the High Plains aquifer. In the western part of the Northern High Plains aquifer, the Brule Formation is overlain by the younger Arikaree Group, mainly composed of very fine to fine-grained sandstone (fig. 6). The Arikaree Group has a maximum thickness of about 1,000 ft in western Nebraska and eastern Wyoming.

The Ogallala Formation is generally coarser and more permeable than the older underlying units and extends over most of the study area (fig. 6, table 2). The Ogallala Formation is a heterogeneous deposit of interlayered stream sediments; lakebeds; and eolian sand, silt, and clay. The Ogallala Formation varies greatly in particle size and physical character over short distances (Cannia and others, 2006). The maximum thickness of the Ogallala Formation is about $984 \mathrm{ft}$ (Hobza and others, 2012; Flynn and Stanton, 2018). Sediments of the Ogallala Formation form the thickest part of the Northern High Plains aquifer. Sediments of the Ogallala Formation are less coarse than the overlying Quaternary alluvial and valleyfill deposits; gravel is not abundant within the Ogallala Formation (Lawton, 1984).

Unconsolidated Quaternary-age sedimentary deposits overlie the older aquifer units. The oldest Quaternary alluvial deposits are largely to the east where the Ogallala Formation is absent (fig. 6, table 2). The next oldest are the dune sands that overlie the central part of the study area (fig. 1), followed by the Quaternary glacial deposits to the northeast (fig. 6). The youngest deposits are the alluvial deposits associated with the modern river basins (labeled "Quaternary valley-fill deposits" in fig. 6). Unconsolidated Quaternary-age alluvial gravel, sand, silt, and clay overlie and are in hydrologic connection with the Ogallala Formation in the eastern parts of the Northern High Plains aquifer. Unconsolidated Quaternary alluvial deposits generally are coarser and more permeable than those of the Ogallala Formation and other older underlying units. Eastward, where the Ogallala Formation is absent, Quaternary alluvial and valley-fill deposits directly overlie poorly permeable bedrock. Where the aquifer consists mainly of Quaternary-age alluvial deposits, it generally is thinner than in areas dominated by the Ogallala Formation; maximum thicknesses of Quaternary alluvium are around $300 \mathrm{ft}$ (Gutentag and others, 1984).

Eolian dune sand deposits of Quaternary age overlie the Ogallala Formation in the central part of the Northern High Plains aquifer (fig. 1, table 2). The largest contiguous area, known as the Nebraska Sand Hills (in north-central Nebraska, labeled as "dune sand" on fig. 1), covers about 20,000 $\mathrm{mi}^{2}$ of the Northern High Plains aquifer and was undergoing dune formation and migration as recently as about 700 years ago (Miao and others, 2007). The dune sands range from very fine to medium sand and, where saturated, are considered part of the High Plains aquifer (Gutentag and others, 1984). The dune sand deposits are as much as $300 \mathrm{ft}$ thick, but on average, their thickness is 100 to $150 \mathrm{ft}$, and therefore dune sands mostly exist as a thin veneer on top of the underlying deposits of the 


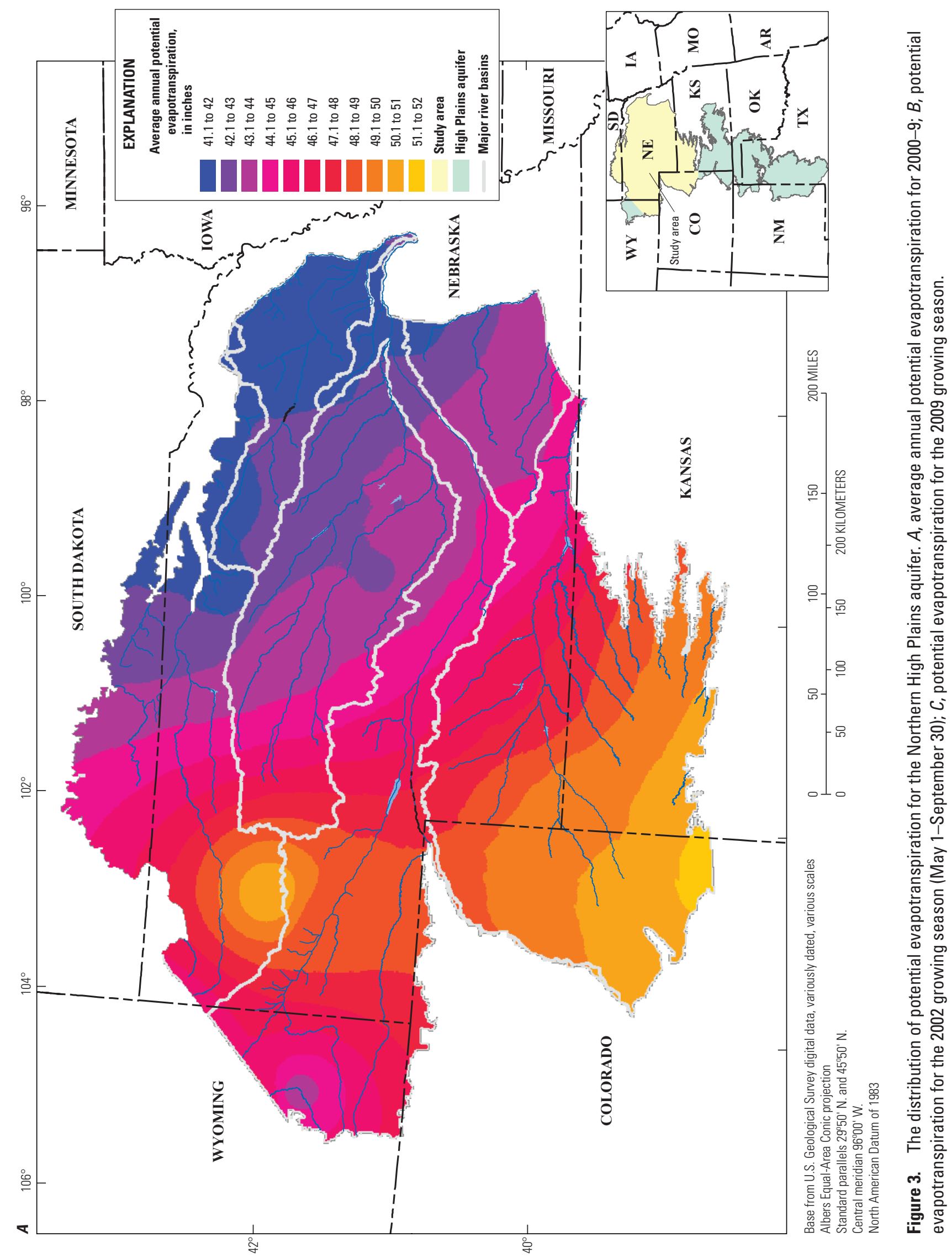




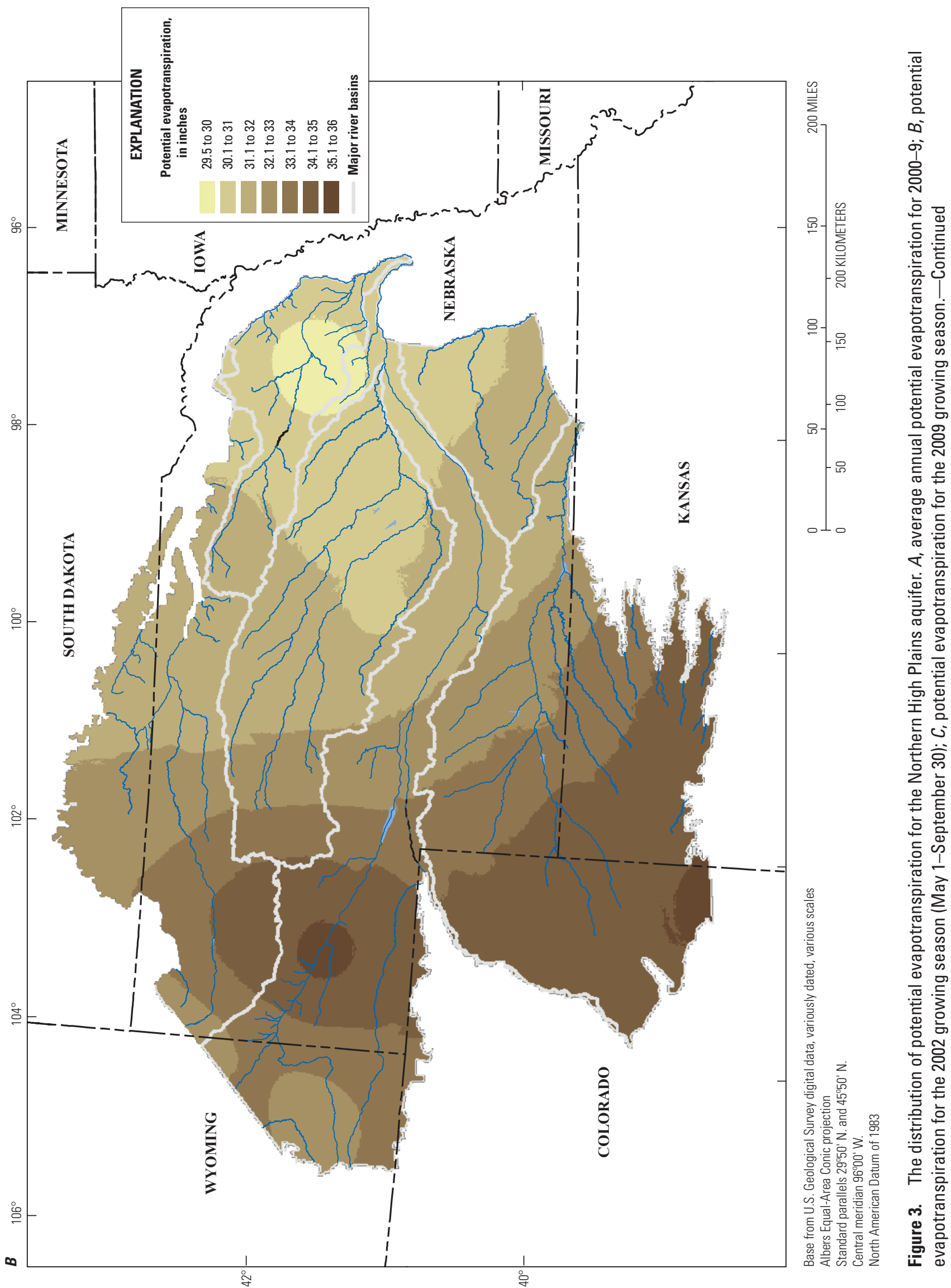




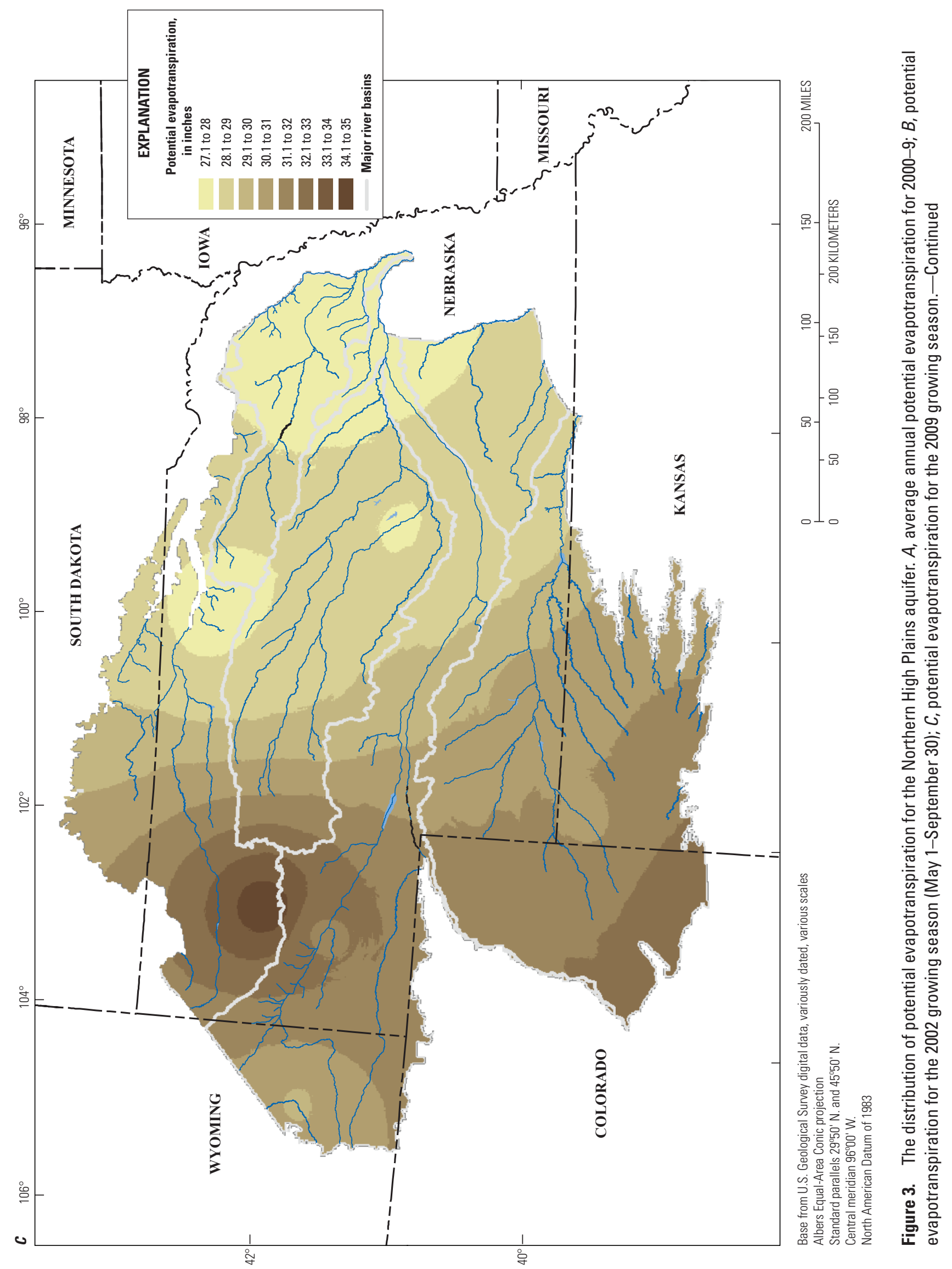




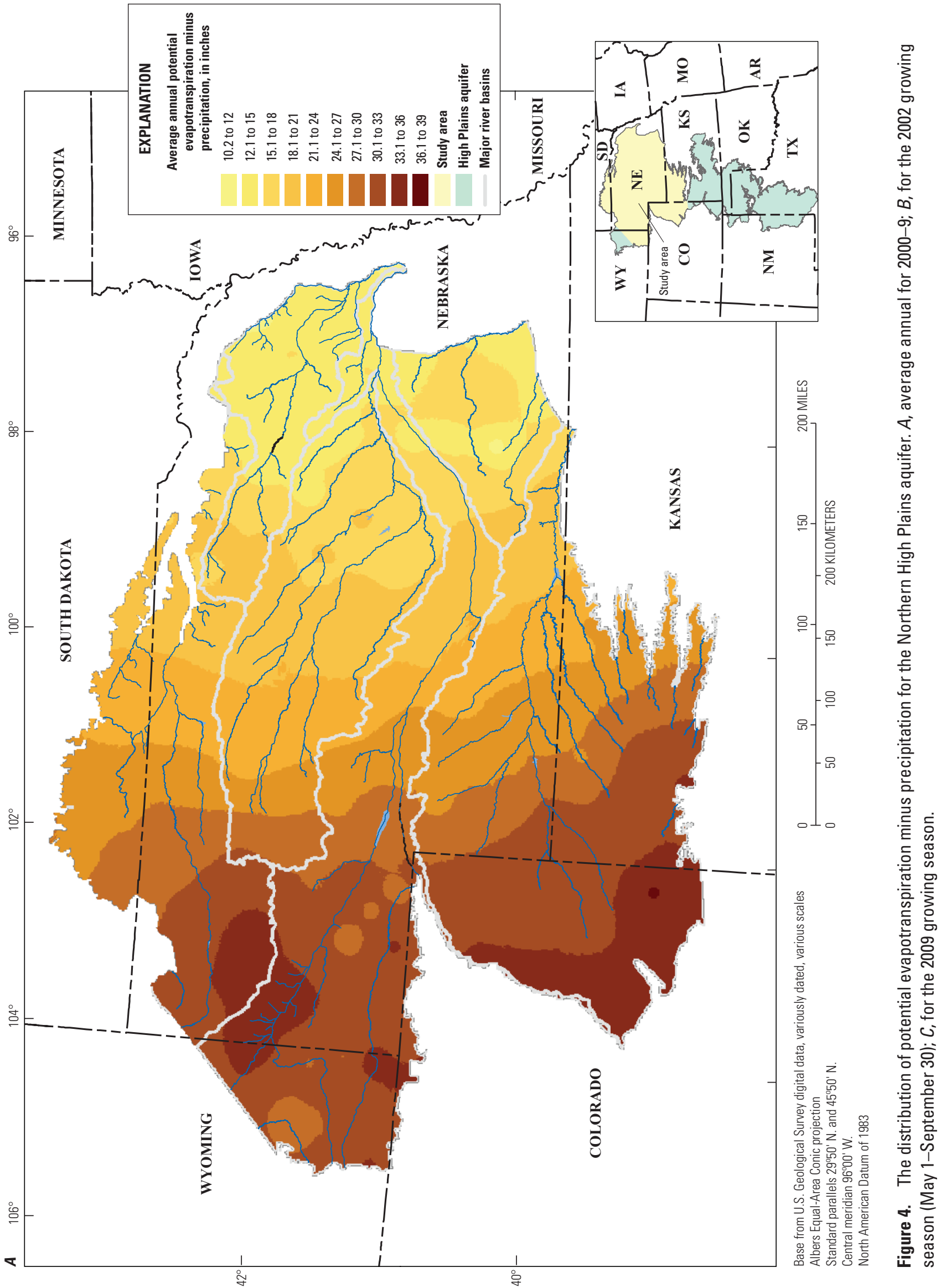




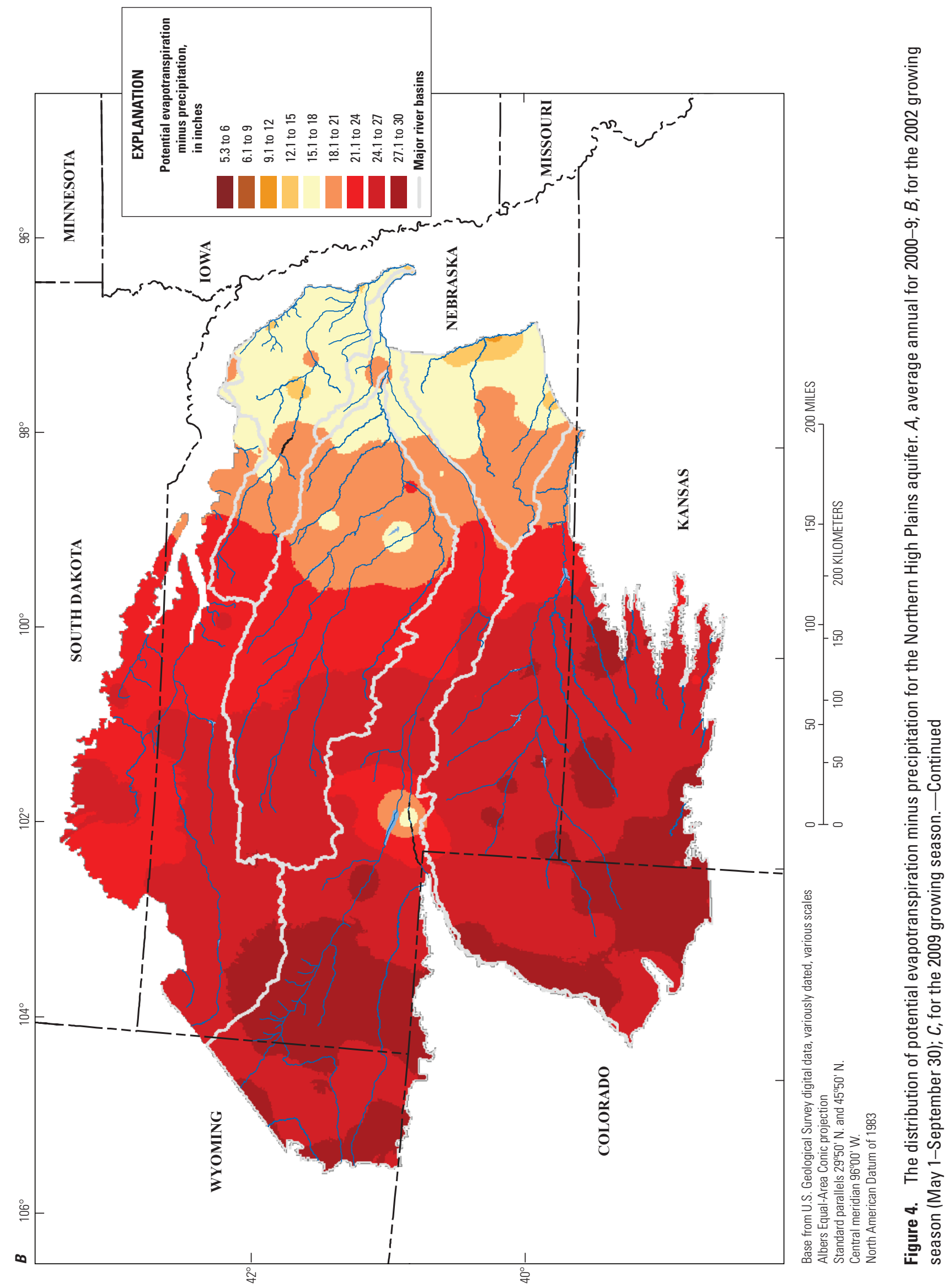




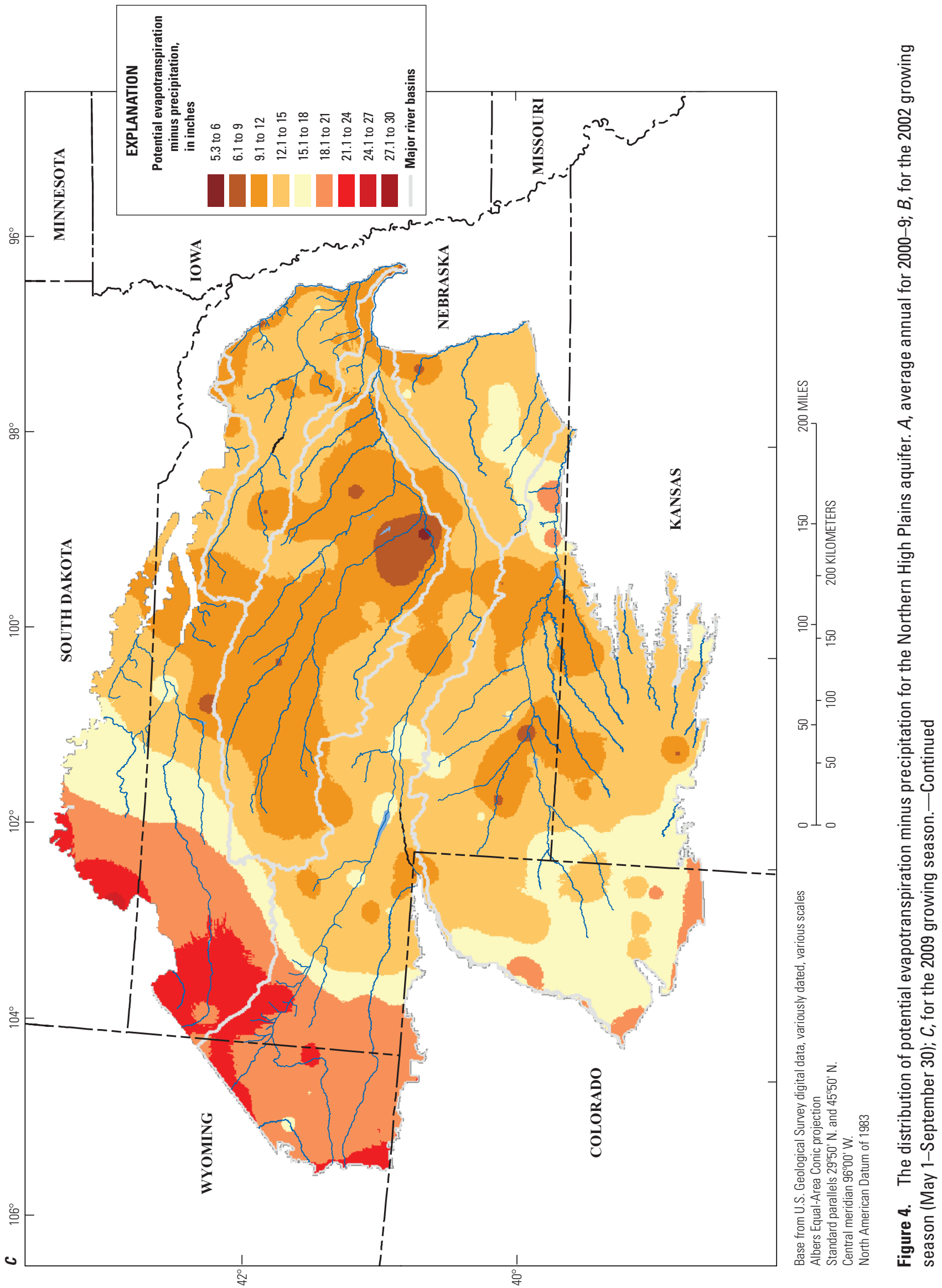




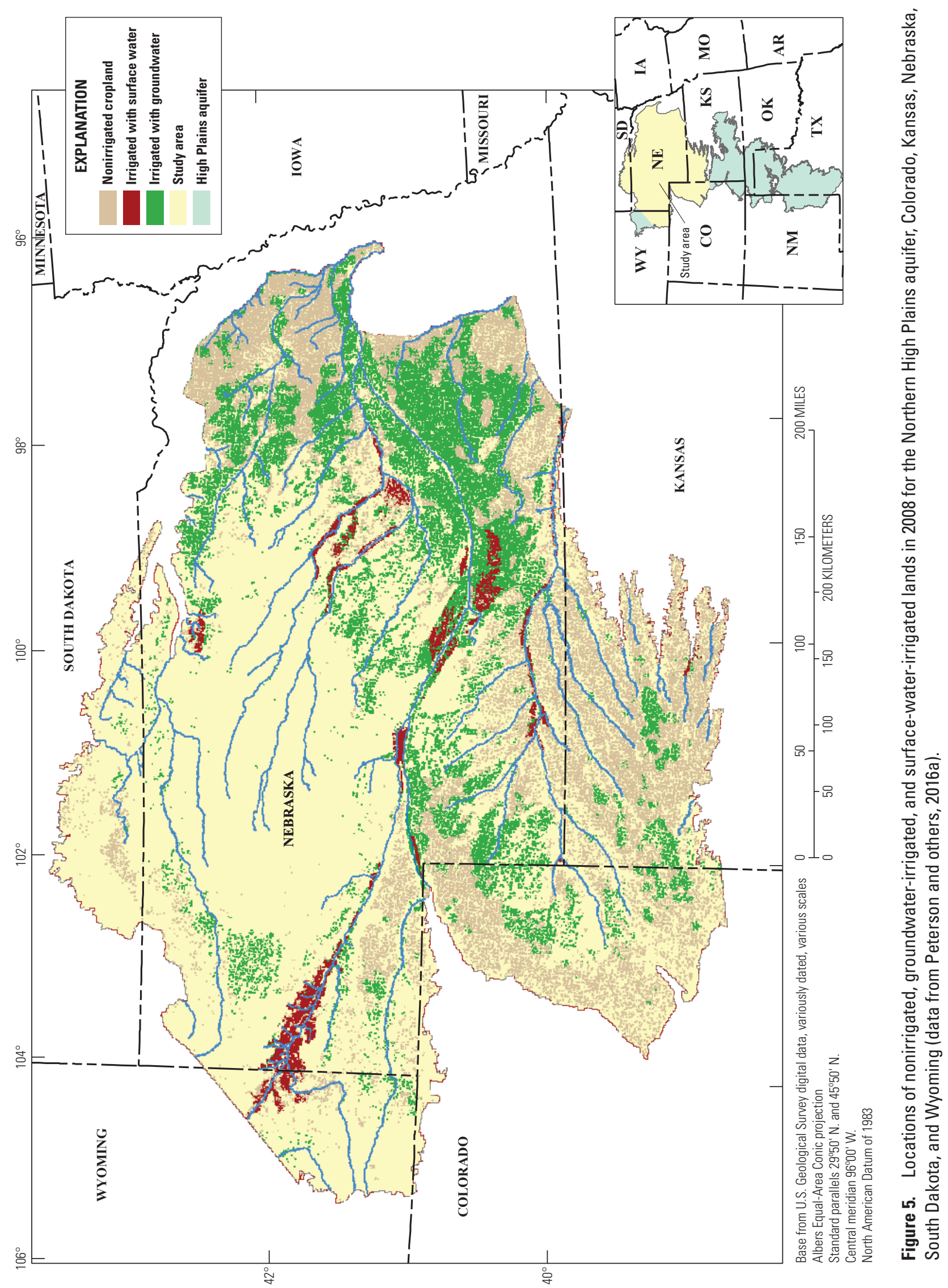




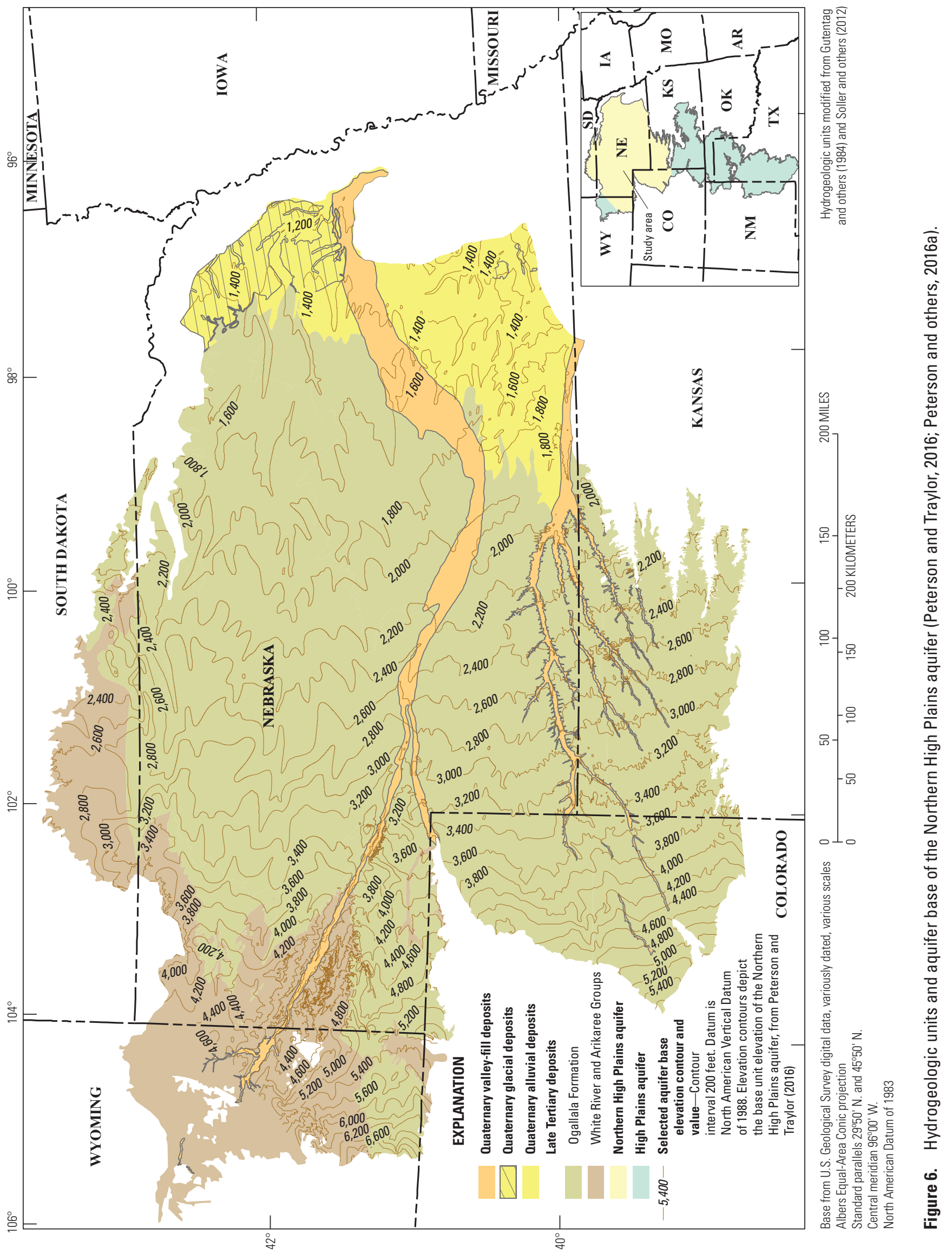




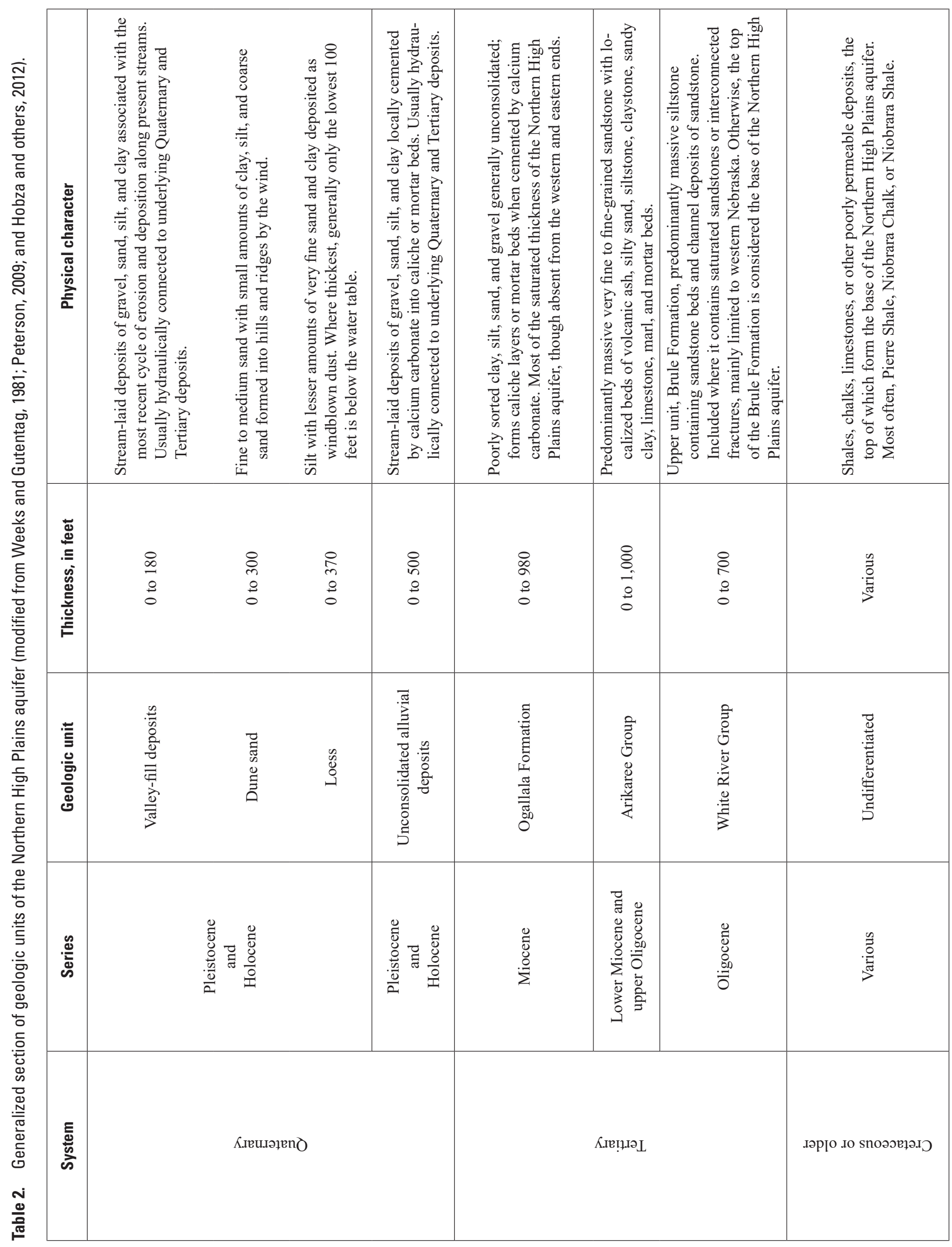


Ogallala Formation (Lawton, 1984). Though the dune sands compose only a minor part of the aquifer, they serve as an important surficial feature enhancing aquifer recharge. Ogallala Formation deposits underlie all Quaternary dune sands in the High Plains aquifer (Muhs, 2007).

Glacial deposits overlie the eastern end of the Northern High Plains aquifer (fig. 6; Condra and others, 1950), forming a region of generally lower aquifer permeability but with poorly defined subsurface character and continuity. Although glacial deposits have been eroded in major stream valleys, glacial till remains in intervalley areas in the northeastern part of the Northern High Plains aquifer (Soller and others, 2012). The glacial deposits consist of till and outwash overlain by eolian loess with possible buried valley-fill deposits of sand and gravel. The distribution of buried valley-fill deposits within or underlying the till is not well known.

Surficial deposits of eolian loess overlying parts of the Northern High Plains aquifer (Muhs and Bettis, 2000) are important because their fine texture limits the maximum infiltration rate and, therefore, the rate of groundwater recharge. Loess is defined as eolian deposits of primarily silt-sized particles that can be as thick as $370 \mathrm{ft}$ (Johnson and Brennan, 1960; Swinehart and others, 1994; Pye, 1995; Condon, 2005; Peterson, 2009). Quaternary-age valley-fill deposits are similar in character and deposition to the Quaternary-age alluvial deposits and are distinguished because the valley-fill deposits are related to erosion and deposition by modern-day stream systems rather than ancient streams. These valley-fill deposits are as much as $180 \mathrm{ft}$ thick (Peterson, 2009) and occupy most major river valleys that cross the Northern High Plains aquifer

The water table is the upper surface of the saturated part of the unconfined aquifer, and it slopes gently west to east, although local variations exist (Gutentag and others, 1984); for example, simulated 2000-9 groundwater levels (Peterson and others, 2016a) indicate deflections around regional stream systems superimposed on the general west to east gradient (fig. 7A). Some steep gradients are indicated in western Nebraska, though in these areas the aquifer is thin and poorly conductive. Saturated thickness is another important aspect defining groundwater availability because it directly relates to the amount of water in storage in the aquifer. The average 2000-9 saturated thickness calculated using the simulated water table (Peterson and others, 2016a) and aquifer base elevation (Peterson and Traylor, 2016) ranged from less than 50 to more than $1,100 \mathrm{ft}$, with an average thickness of $249 \mathrm{ft}$ (fig. $7 B$ ). The aquifer is thickest in north-central Nebraska and thinnest in the east, west, and south.

Depth to groundwater (or the water table) is an important characteristic influencing irrigation well pumping lift, interaction with surface water, and evapotranspiration. Based on average simulated water table elevations from 2000 to 2009 (Peterson and others, 2016a), depth to groundwater ranges from less than $10 \mathrm{ft}$ near major rivers (such as the Platte River) and in the upstream end of the Elkhorn River Basin to more than $500 \mathrm{ft}$ in uplands in the western part of the area (fig.7C). Depth to water calculated from the simulated water table elevation indicates the same general patterns as published in Stanton and others (2011). The median depth to groundwater for the study area is $84 \mathrm{ft}$.

\section{Methods of Analysis}

Two process-based methods contributed to the analysis of groundwater availability described in this report: a Soil-WaterBalance (SWB) model (Westenbroek and others, 2010) was used to estimate recharge and groundwater withdrawals for irrigation, and a Newton formulation of the U.S. Geological Survey (USGS) modular finite-difference groundwater-flow model (MODFLOW-NWT, Niswonger and others, 2011) was used to evaluate forecasted stream base flow and simulated groundwater budgets (Peterson and others, 2016a). As in Peterson and others (2016a), recharge and groundwater withdrawals for irrigation were estimated with SWB, then used as inputs to the MODFLOW-NWT groundwater model; therefore, for the analysis documented in this report, the SWB and MODFLOW-NWT models were used to simulate 2009-49 conditions for five future forecasts.

\section{Future Forecasts}

The forecasts are a baseline forecast, a forecast using A2 land cover and 2004 climate data (A2LC), a forecast using B2 land cover and 2004 climate data (B2LC), a forecast using 2009 land cover and Geophysical Fluid Dynamics Laboratory Earth System Model Second Generation downscaled daily outputs (GFDL), and a forecast using 2009 land cover and Japanese Meteorological Research Institute Coupled Global Climate Model Version 3 downscaled daily outputs (MRI). The baseline forecast was constructed to represent a static repeating condition to evaluate effects of current (as of 2009) practices and average climate continuing into the future. The A2LC and B2LC forecasts also used 2004 climate data combined with A2 land cover and B2 land cover (modified from Houston and others, 2013), respectively, to evaluate the effects of possible land development patterns. A2 land cover of irrigated agricultural area increases by 23 percent from 2009 to 2049, as compared with 13 percent for B2 land cover. The GFDL and MRI forecasts were constructed to evaluate the effects of potentially different future climate, and used 2009 land cover combined with alternative climate data derived from downscalings of global climate model data (Bureau of Reclamation, 2013). Additional details are in the "Data Used to Forecast Future Conditions" section.

Adjustments to recharge estimated during calibration (Peterson and others, 2016a) also were applied to the forecast period (2009-49) recharge. Use of different SWB inputs to represent changes in land cover or climate changed the SWB and corresponding groundwater model outputs. To characterize the effects, aquifer and basin-scale groundwater budgets for the baseline forecast were compared against 2000-9 


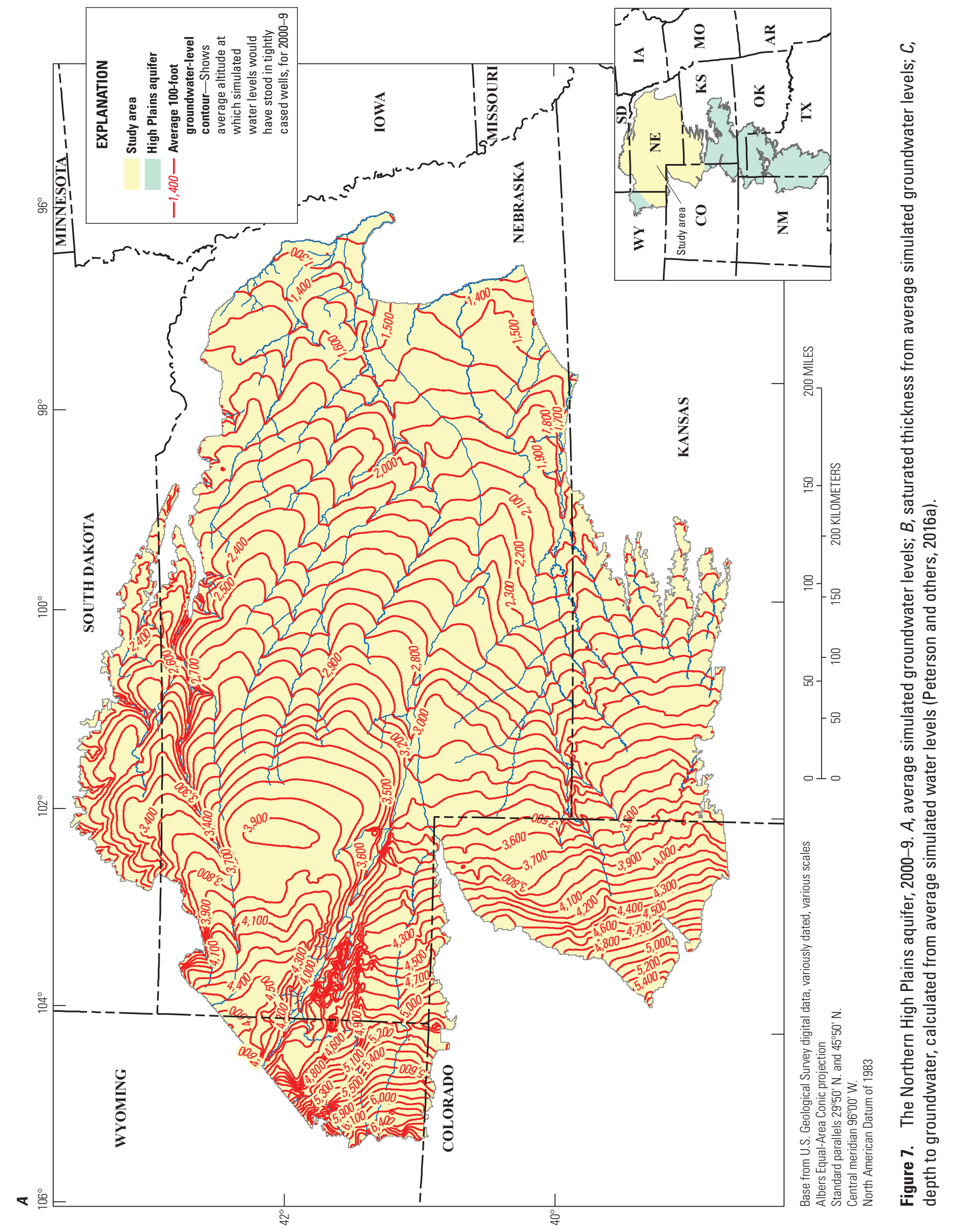




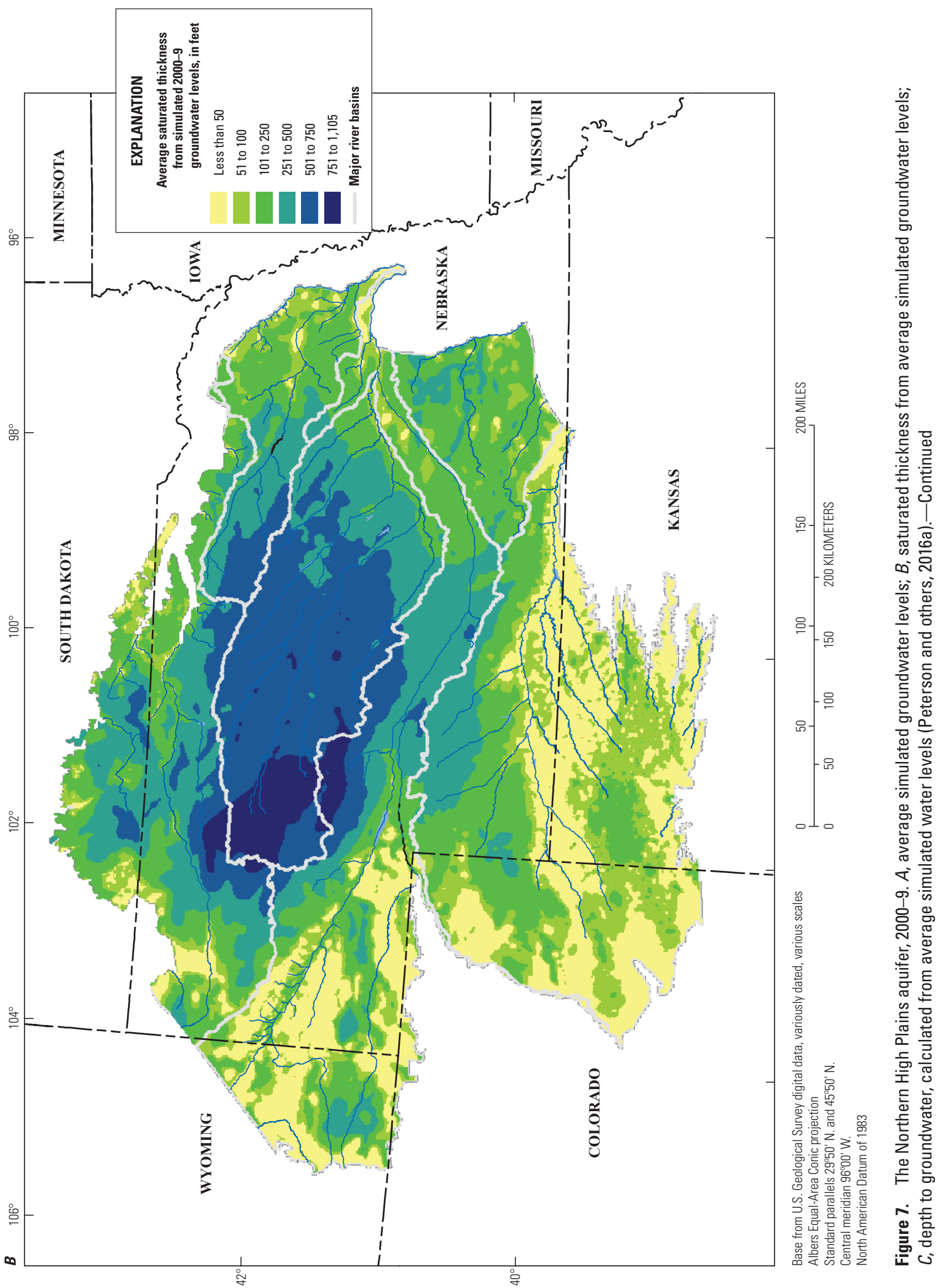




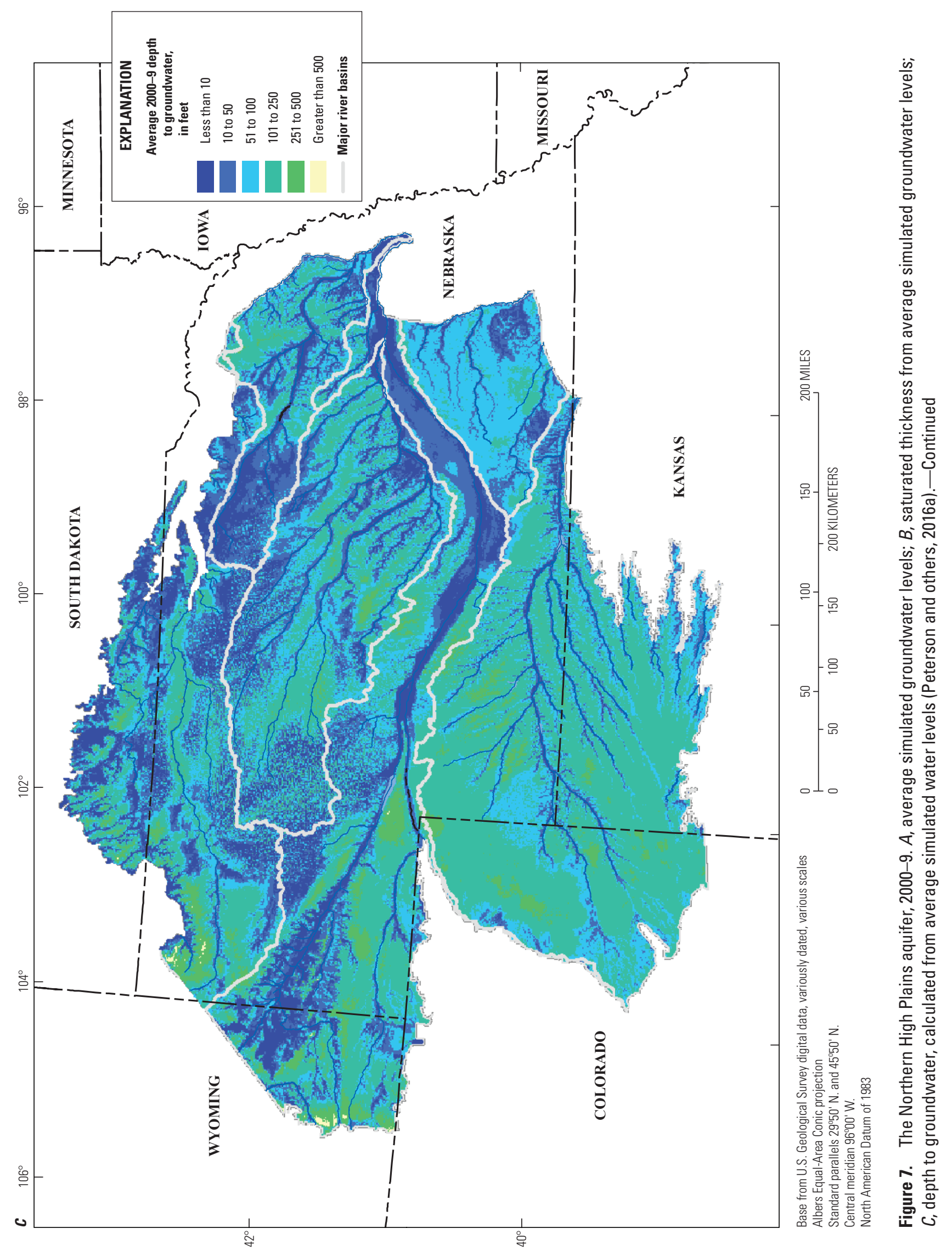


average conditions. Next, four alternative forecasts were compared against baseline (no change from 2009) outputs, and for most basins, simulated flow from major streams was compared against basin-scale flow. Groundwater model outputs also were used to analyze potential improvements to the (2009) groundwater monitoring network, by evaluating the variability in simulated water levels across all five forecasts, at a random sampling of locations where groundwater levels were not monitored (as of 2009).

\section{Observation Network Analysis}

To select locations to evaluate the worth of new potential water-level observations, a vector representation of model cells was used in tandem with measured groundwater levels used to calibrate the 1940-2009 model (Peterson and others, 2016a). First, the water levels used to calibrate the last year (May 1, 2008, to April 30, 2009) of the Northern High Plains aquifer groundwater model were extracted from the dataset (fig. 8) because these water levels represent the most developed state of monitoring of the aquifer; the largest number of wells generally was near the end of the calibration period. These water-level locations were joined to the active cells of the groundwater model that were more than 5 miles (mi) inside the area boundary. Cells within 2 mi of existing water levels in 2009 were removed on the assumption that only cells that were more than 2 mi from existing water levels would be considered as potentially valuable new observed water levels. This removal resulted in 107,205 cells where potential new observations could be considered, and each cell was assigned a random number between 0 and 107,204. Experimentation indicated that selecting the highest 2,462 cells as potential sampling locations gave a distribution across the model domain yet was still practical to evaluate (fig. 9). Though the 2-mi distance was arbitrary, the effect of that selection was minimized by the process of culling potential locations using the random grid. Using a larger distance would have resulted in fewer potential locations subjected to culling but probably would not have affected the general results of the analysis.

The groundwater-level observation network was analyzed for these locations (fig. 9) using groundwater levels extracted from the five future forecasts simulated with the numerical model (referred to as baseline, A2LC, B2LC, GFDL, and MRI). The standard deviation of groundwater levels across all seasons of the five future forecasts was taken as an indication of larger variability in the future forecasts, similar to the approach of Masterson and others (2016), who used variability in future water levels as an indicator of sensitivity to climate inputs. For this study, variability in future forecast water levels was taken as an indicator of where additional data collection would be most valuable for improving the model calibration by either confirming and measuring the variability or refuting it and providing additional data to constrain the model calibration.

\section{Groundwater Availability of the Northern High Plains Aquifer}

This section of the report describes the groundwater availability of the Northern High Plains aquifer, during predevelopment (defined as 1940-49) and postdevelopment (defined as 2000-9) conditions, as well as across five alternative future forecasts representing 2009-49. Groundwater availability was evaluated by comparing regional and subregional simulated groundwater budgets for the different periods. Simulated stream base flows at select USGS streamgages were compared between forecasts when they indicated results different from those indicated by water budgets of the containing river basin. This section of the report also describes an evaluation of potential monitoring improvements important for informing groundwater availability.

\section{Predevelopment Hydrologic System}

This section of the report describes the predevelopment hydrologic system in terms of the processing causing gains and losses to the groundwater system before major groundwater withdrawals for irrigation, frequently defined as around 1940 or 1950, and defined in this report as 1940-49. This section also describes the corresponding 1940-49 simulated water budget components of the calibrated Northern High Plains aquifer model (Peterson and others, 2016a).

\section{Description of the Predevelopment Hydrologic System}

The predevelopment hydrologic system is defined herein to mean before major groundwater withdrawals for irrigation, frequently considered to be around 1940 (Weeks and others, 1988) or 1950 (Peterson, 2009). Groundwater had been developed primarily for irrigation on a local scale before 1950 , mostly where depth to water was small, such as near Grand Island, Nebr. (figs. 1, 7C, 10). The largest predevelopment hydrologic processes included recharge from precipitation, groundwater discharge to streams, and groundwater discharge to evapotranspiration. Groundwater has been presumed to have discharged to (or been captured by) evapotranspiration only near major rivers and in other places where the depth to groundwater is less than several feet below land surface.

The earliest human-instigated changes to the hydrologic system were the diversion of streams and rivers to irrigate adjacent lands before the 20th century (State Board of Irrigation, 1899). At that time, surface-water irrigation was limited primarily to areas within $10 \mathrm{mi}$ of major rivers and streams, starting with cooperation of neighbors and hand-dug ditches and later being developed at a larger scale in western Nebraska by the Bureau of Reclamation (Autobee, 1996) and in central Nebraska through the Public Works Administration (Central Nebraska Public Power and Irrigation District, 2018). The 


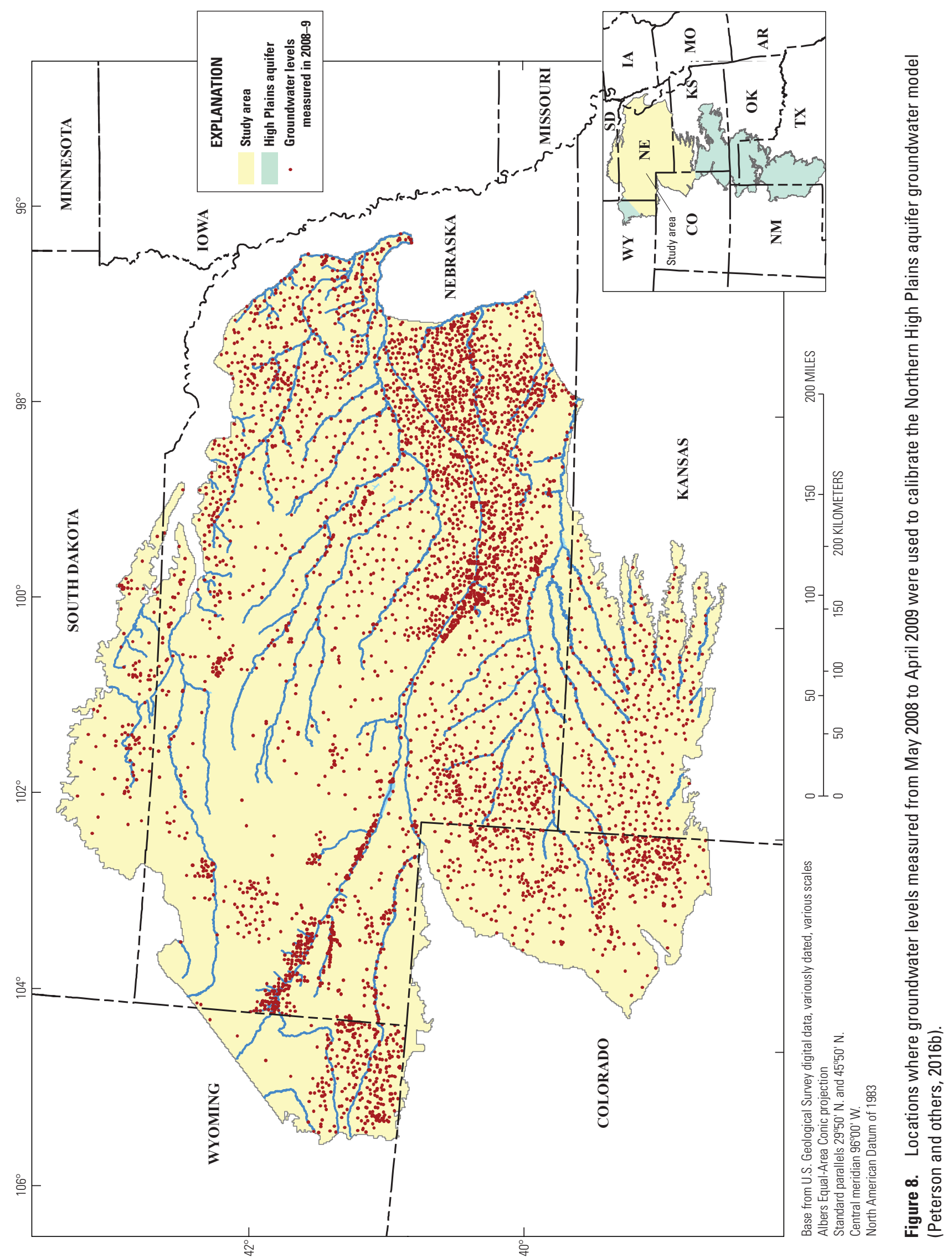




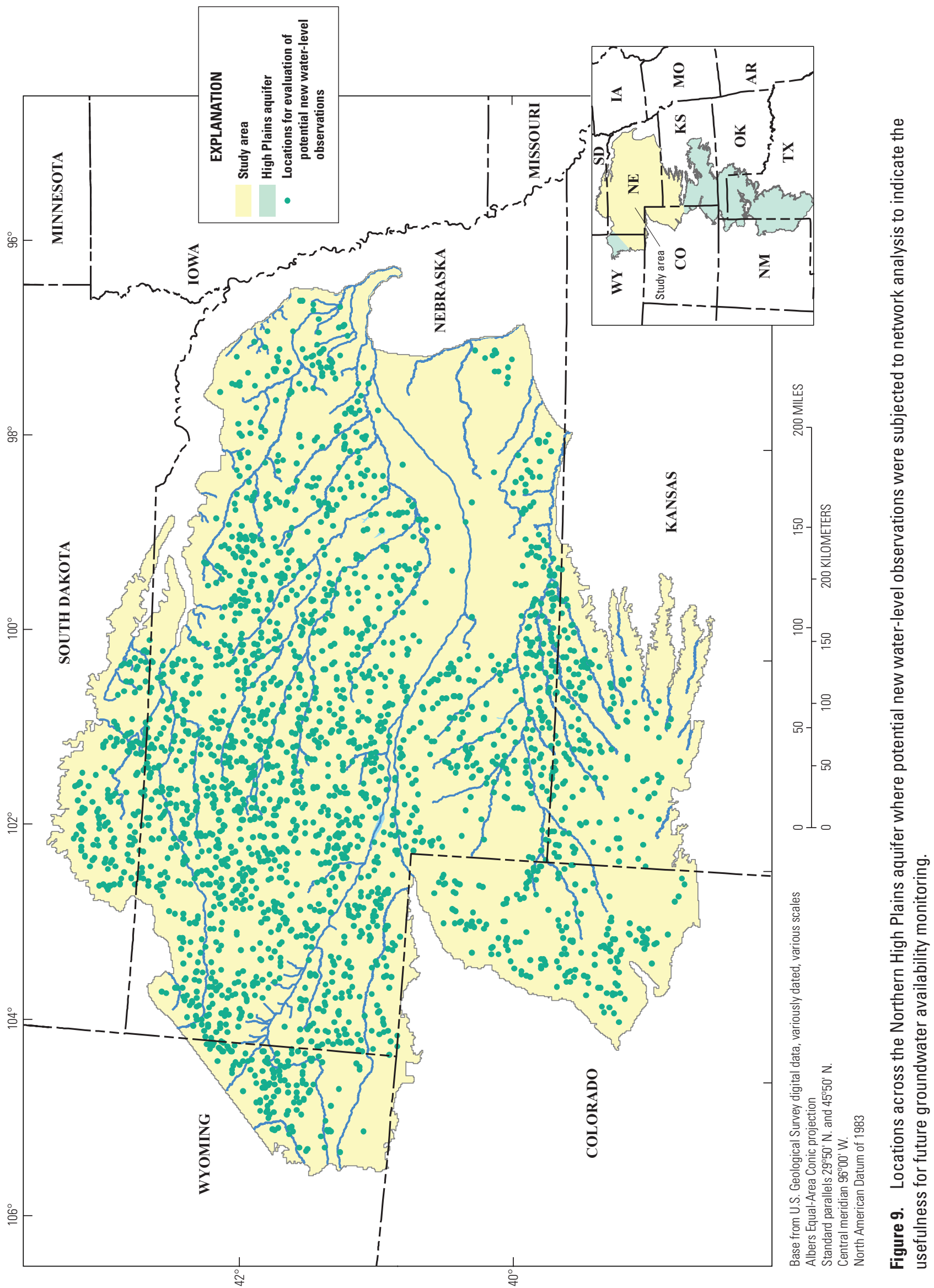




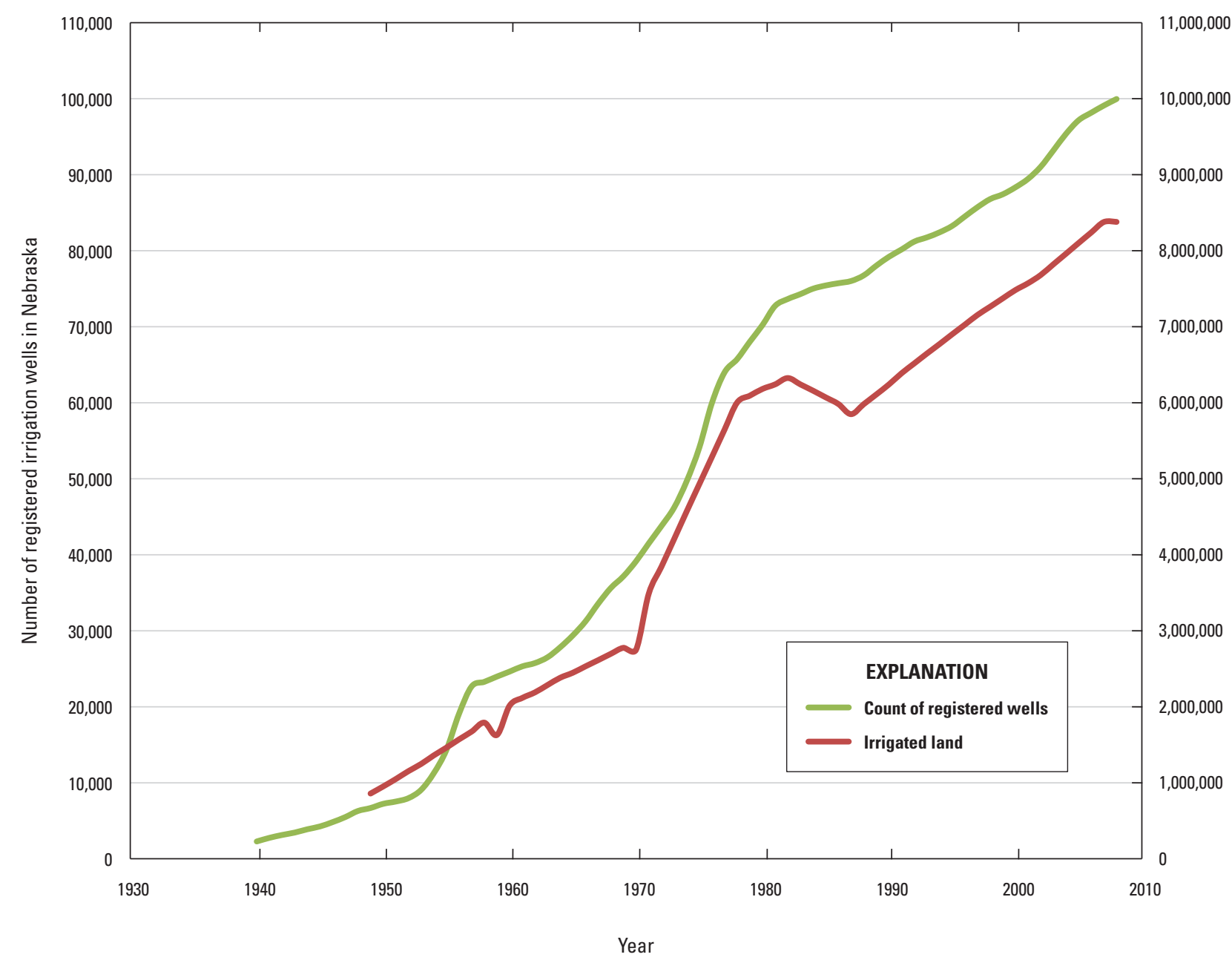

Figure 10. Nebraska registered irrigation wells and irrigated land for the Northern High Plains aquifer groundwater model, 1940-2009 (data from Nebraska Department of Natural Resources, 2015; Peterson and others, 2016b).

diversion, transmittal, and application of surface-water irrigation created large local changes to the groundwater system because of the influx of a new large amount of water and related seepage into the subsurface. Most surface-water irrigation projects were in place by 1955 , covering 1.7 percent of the study area (also equivalent to 13 percent of irrigated land within the study area; Peterson and others, 2016a).

Irrigated agricultural land on the Northern High Plains aquifer expanded more than tenfold from only 857,000 acres in 1949 to 8,379,000 acres by 2008 (fig. 10; Peterson and others, 2016a). Most surface-water irrigation was substantially in place by 1955 and remained through 2008 (fig. 5). The remainder of irrigation expansion was through development of groundwater; for example, the cumulative number of irrigation wells registered overlying the High Plains aquifer in Nebraska increased from only a few thousand in 1940 to more than 70,000 in 1980 and 100,000 by 2009 (fig. 10; Nebraska Department of Natural Resources, 2015).

\section{Predevelopment Water Budget}

For the Northern High Plains aquifer, average 1940-49 simulated gains (inflows) were predominantly from recharge from precipitation (93 percent), followed by a far smaller amount from recharge from canal seepage (7 percent; fig. 11A; table 3). Average 1940-49 simulated losses (outflows) were largest for changes in storage resulting in groundwater-level increases (45 percent), with 6.8 million acre-ft per year leaving the flow system and replenishing groundwater in storage (fig. 11A). It was not possible to assess the uncertainty associated with the net replenishment to storage for this period; there were not large outflows to a net replenishment to storage in any other parts of the simulated period (fig. 12), and data available to calibrate the 1940-49 part of the simulation were relatively sparse compared with later parts of the simulation, such as 2000-9 (Peterson and others, 2016a). The net replenishment to groundwater storage for this period correlates to 


\section{A. $1940-49$}

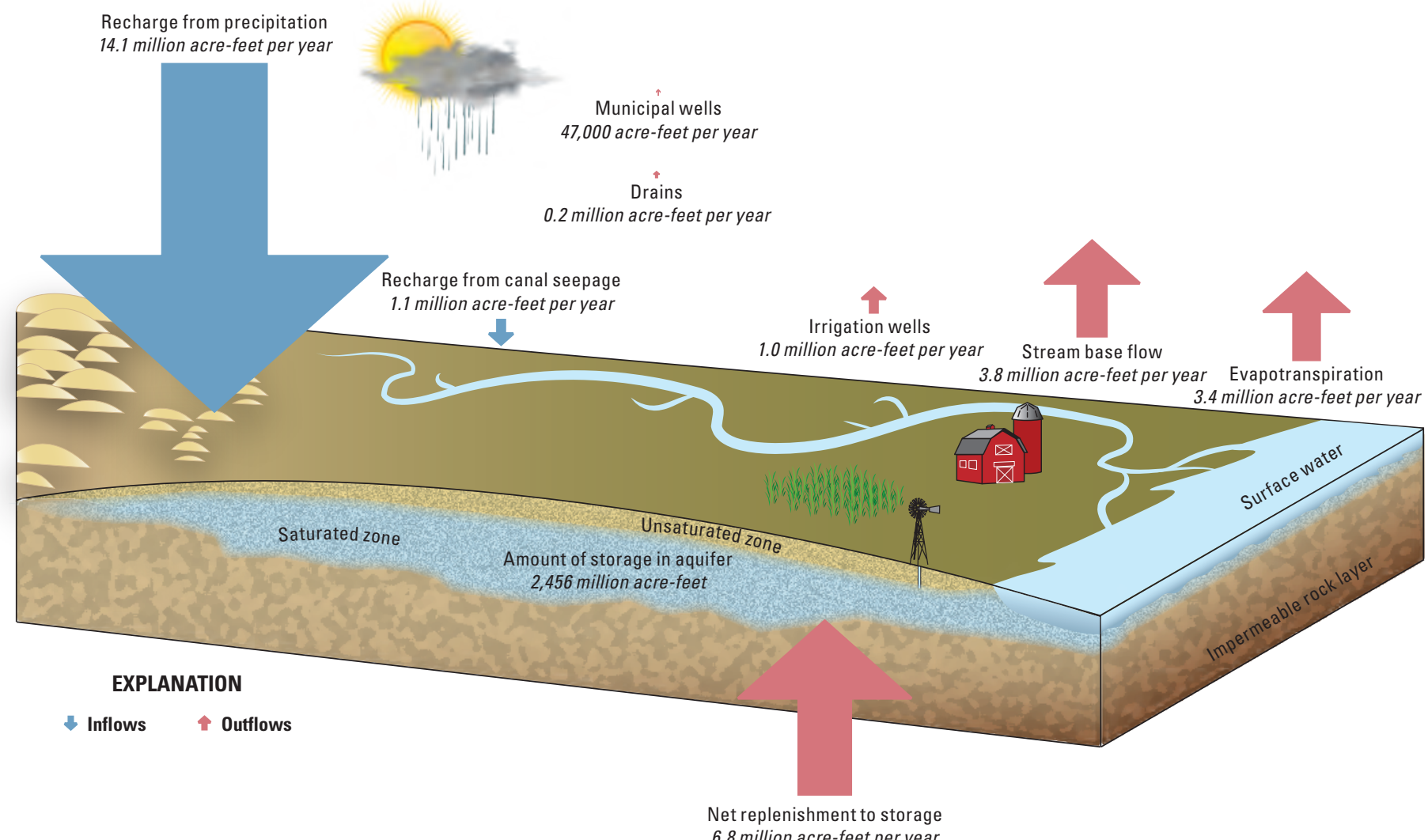

\section{B. 2000-9}

Recharge from precipitation 10.1 million acre-feet per year
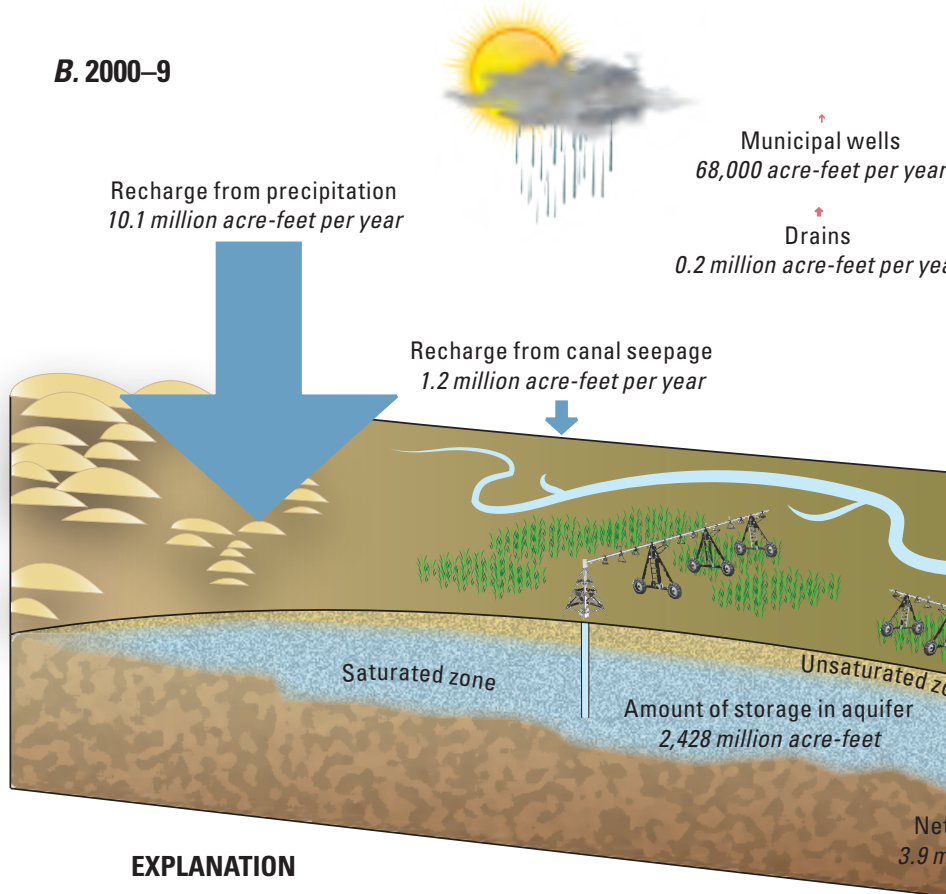

0.2 million acre-feet per year

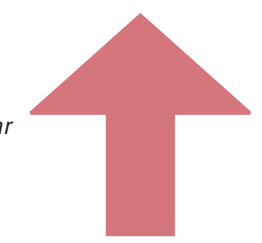
7.5 million acre-feet per year Stream base flow

3.9 million acre-feet per year Evapotranspiration 3.5 million acre-feet per year

$\checkmark$ Inflows

- Outflows

Figure 11. Conceptual diagrams comparing average annual simulated water budget inflows and outflows by source and the amount of water in storage in the Northern High Plains aquifer. $A$, for 1940-49; $B$, for 2000-9; $C$, for five forecasts representing 2009-49. 


\section{2009-49 baseline and forecasts}

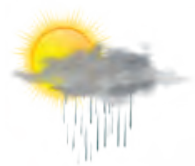

Recharge from precipitation 11.6 million acre-feet per year 11.6 million acre-feet per year 11.7 million acre-feet per year 10.2 million acre-feet per year 9.8 million acre-feet per year

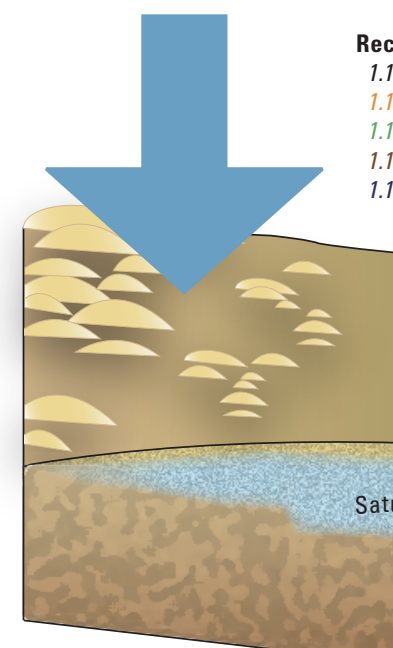

Inflows from west

Less than 0.1 million acre-feet per year Less than 0.1 million acre-feet per year Less than 0.1 million acre-feet per year Less than 0.1 million acre-feet per year Less than 0.1 million acre-feet per year
Net release from storage 1.6 million acre-feet per year 2.2 million acre-feet per year 1.9 million acre-feet per year 2.0 million acre-feet per year 2.5 million acre-feet per year

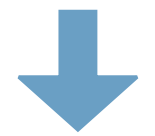

Recharge from canal seepage 1.1 million acre-feet per year 1.1 million acre-feet per year 1.1 million acre-feet per year 1.1 million acre-feet per year 1.1 million acre-feet per year
Out

Outflows to reservoirs Less than 0.1 million acre-feet per year Less than 0.1 million acre-feet per year Less than 0.1 million acre-feet per year Less than 0.1 million acre-feet per year Less than 0.1 million acre-feet per year

\section{Municipal wells}

Less than 0.1 million acre-feet per year Less than 0.1 million acre-feet per year Less than 0.1 million acre-feet per year Less than 0.1 million acre-feet per year Less than 0.1 million acre-feet per year

\section{$\uparrow$ \\ Drains}

0.2 million acre-feet per year

0.2 million acre-feet per year

0.2 million acre-feet per year

0.2 million acre-feet per year

0.2 million acre-feet per year

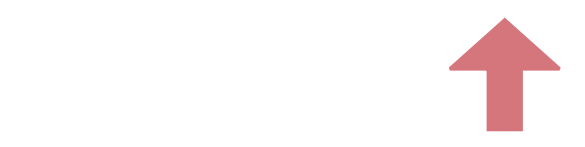

Evapotranspiration 3.4 million acre-feet per year 3.3 million acre-feet per year 3.4 million acre-feet per year 3.3 million acre-feet per year 3.3 million acre-feet per year

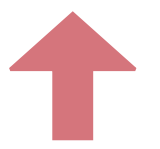

Stream base flow 6.7 million acre-feet per year 7.5 million acre-feet per year 7.2 million acre-feet per year 6.3 million acre-feet per year 6.4 million acre-feet per year 3.8 million acre-feet per year 3.9 million acre-feet per year 3.6 million acre-feet per year 3.6 million acre-feet per year
4.0 million acre-feet per year $+$

Amount of storage in aquifer 2,372 million acre-feet 2,350 million acre-feet 2,359 million acre-feet 2,355 million acre-feet 2,335 million acre-feet

\section{EXPLANATION}

[A2LC, forecast using A2 land cover (25-percent increase in irrigated agriculture) and 2004 climate data; B2LC, forecast using B2 land cover (12-percent increase in irrigated agriculture and 50-percent decrease in dryland agriculture) and 2004 climate data; GFDL, forecast using 2009 land cover and Geophysical Fluid Dynamics Laboratory Earth System Model Second Generation downscaled daily outputs; MRI, forecast using 2009 land cover and Japanese Meteorological Research Institute Coupled Global Climate Model Version 3 downscaled daily outputs]

\begin{tabular}{|l|l|}
\hline Baseline & \multicolumn{1}{|c}{ Inflows } \\
\hline A2LC forecast & + Outflows \\
\hline B2LC forecast & \\
\hline GFDL forecast \\
\hline MRI forecast
\end{tabular}

Figure 11. Conceptual diagrams comparing average annual simulated water budget inflows and outflows by source and the amount of water in storage in the Northern High Plains aquifer. $A$, for 1940-49; $B$, for 2000-9; $C$, for five forecasts representing 2009-49.-Continued 
Table 3. Summary of simulated average annual groundwater budgets for 1940-49 and 2000-9, simulated by the Northern High Plains aquifer groundwater-flow model in Colorado, Kansas, Nebraska, South Dakota, and Wyoming (Peterson and others, 2016a).

[Parenthetical entries are MODFLOW package codes from Niswonger and others (2011); <, less than; --, zero]

\begin{tabular}{|c|c|c|c|c|}
\hline \multirow[b]{2}{*}{$\begin{array}{l}\text { Water budget component } \\
\text { (MODFLOW package } \\
\text { in parentheses) }\end{array}$} & \multicolumn{2}{|c|}{$1940-49$} & \multicolumn{2}{|c|}{$2000-9$} \\
\hline & $\begin{array}{l}\text { Quantity average } \\
\text { (cubic feet } \\
\text { per second) }\end{array}$ & $\begin{array}{l}\text { Relative quantity } \\
\text { (percentage of total } \\
\text { budget) }\end{array}$ & $\begin{array}{l}\text { Quantity average } \\
\text { (cubic feet } \\
\text { per second) }\end{array}$ & $\begin{array}{c}\text { Relative quantity } \\
\text { (percentage of total } \\
\text { budget) }\end{array}$ \\
\hline \multicolumn{5}{|c|}{ Inflows } \\
\hline Recharge (RCH) & 20,960 & 100 & 15,638 & 74 \\
\hline -from canal seepage & 1,489 & 7 & 1,641 & 8 \\
\hline -from precipitation & 19,472 & 93 & 13,997 & 66 \\
\hline $\begin{array}{l}\text { Groundwater inflows simu- } \\
\text { lated as specified water levels } \\
\text { (BAS) }\end{array}$ & 47 & $<1$ & 54 & $<1$ \\
\hline $\begin{array}{l}\text { Head dependent bounds repre- } \\
\text { senting reservoirs (GHB) }\end{array}$ & 17 & $<1$ & -- & -- \\
\hline $\begin{array}{l}\text { Change in storage: groundwater- } \\
\text { level decreases (UPW) }\end{array}$ & -- & -- & 5,366 & 25 \\
\hline Total inflows & 21,025 & 100 & 21,058 & 100 \\
\hline \multicolumn{5}{|c|}{ Outflows } \\
\hline $\begin{array}{l}\text { Change in storage: groundwater- } \\
\text { level increases (UPW) }\end{array}$ & 9,371 & 45 & -- & -- \\
\hline Evapotranspiration (EVT) & 4,646 & 22 & 4,873 & 23 \\
\hline Irrigation wells (WEL) & 1,416 & 7 & 10,288 & 49 \\
\hline Drains (DRN) & 254 & 1 & 301 & 1 \\
\hline $\begin{array}{l}\text { Head dependent bounds repre- } \\
\text { senting reservoirs (GHB) }\end{array}$ & -- & -- & 71 & $<1$ \\
\hline Municipal wells (MNW2) & 65 & $<1$ & 95 & $<1$ \\
\hline Stream base flow (SFR) & 5,273 & 25 & 5,437 & 26 \\
\hline Total outflows & 21,025 & 100 & 21,065 & 100 \\
\hline
\end{tabular}

groundwater-level increases and probably occurred because of a combination of climatic conditions, as well as the introduction of substantial additional recharge from leakage because of canal systems that began operations around that time.

The next largest simulated loss was to streams (25 percent), followed by losses to evapotranspiration (22 percent; table 3). Losses to irrigation wells were only 7 percent of the total outflows and about the same magnitude as the gains of recharge from canal seepage. Other outflow components were much smaller, such as outflows to municipal wells, reservoirs, and drains (seeps and springs near the edges of the aquifer). The amount of groundwater in storage was about 2,456 million acre-ft (fig. 11A).

Average predevelopment (1940-49) simulated water budgets for the six major basins of the Northern High Plains aquifer generally followed the same distribution as the regional Northern High Plains aquifer (fig. 13A); however, in the Elkhorn, Platte, and Republican River Basins, evapotranspiration was larger than losses to streams (creating base flow), contrary to the whole. This difference was caused by the evapotranspiration rate in the Platte and Republican River Basins, which is larger in the southwest than in the rest of the area (fig. $3 A$ ). In addition, evapotranspiration was limited to groundwater within $7 \mathrm{ft}$ of the land surface, and much of the Elkhorn River Basin has shallow depths to water, as does much of the Platte River Basin (fig. 7C).

In contrast, the Niobrara and Loup River Basins had smaller evapotranspiration and larger 1940-49 recharge than other areas, and together, gained nearly half of the recharge of the Northern High Plains aquifer (fig. 13A, table 3). Recharge is likely larger than in other areas because of cooler temperatures resulting in decreased loss to evapotranspiration, as well as sandy soils facilitating infiltration of precipitation to become groundwater recharge. The Niobrara and Loup River Basins also had larger simulated losses to streams than other areas, and together constituted more than half of the losses to 


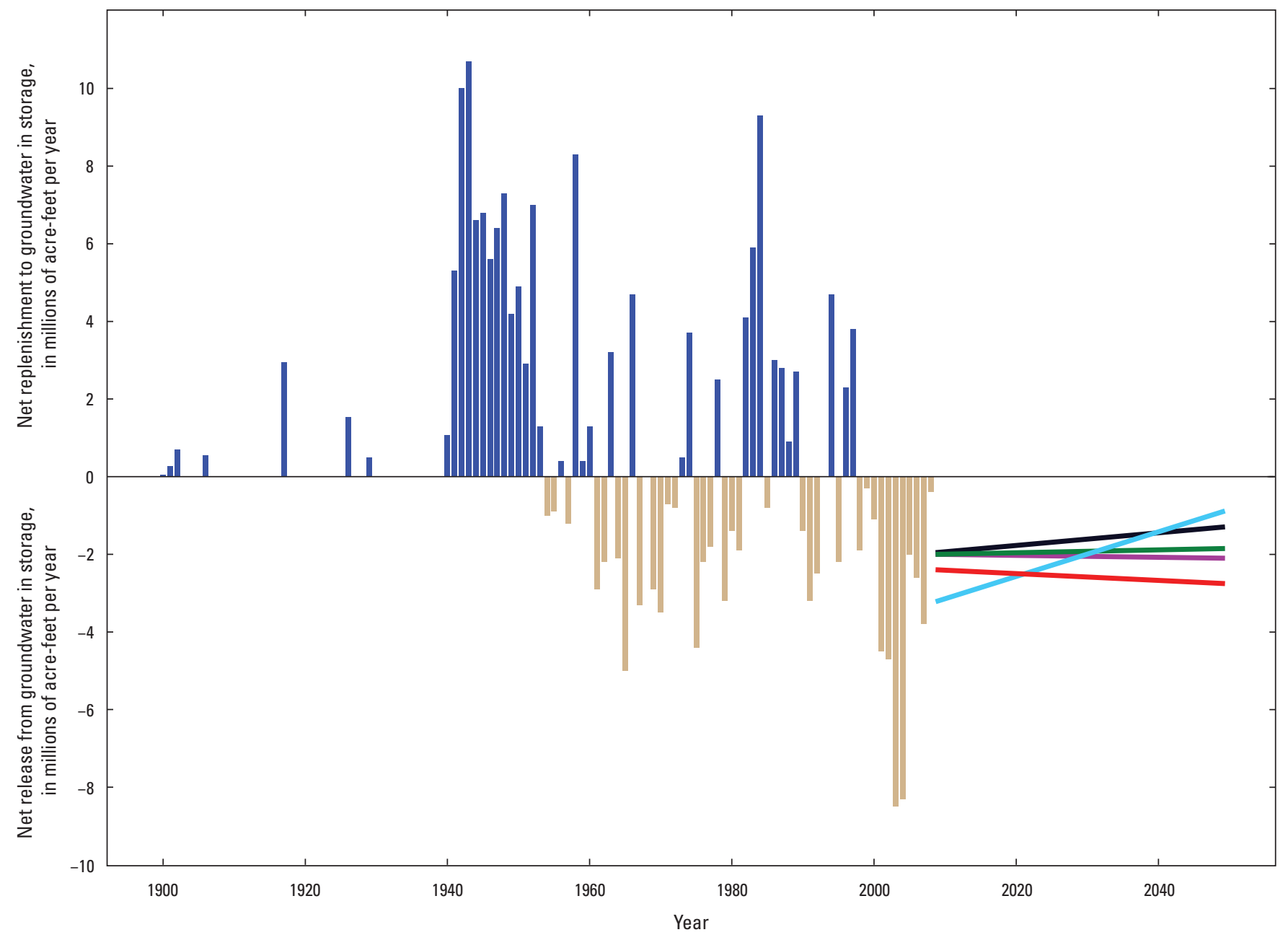

\section{EXPLANATION}

[A2LC, forecast using A2 land cover and 2004 climate data; B2LC, forecast using B2 land cover and 2004 climate data; GFDL, forecast using 2009 land cover and Geophysical Fluid Dynamics Laboratory Earth Systems Model Second Generation downscaled daily outputs; MRI, forecast using 2009 land cover and Japanese Meteorological Research Institute Coupled Global Climate Model Version 3 downscaled daily outputs]

\section{0-2009}

- Net replenishment to storage

- Net release from storage

\section{9-49 forecast trends}

Baseline forecast
A2LC
B2LC
GFDL
$n \cap n !$

Figure 12. Net release from and net replenishment to groundwater in storage of the Northern High Plains aquifer for 1900-2009 and trends of change in storage for five forecasts representing 2009-49. 


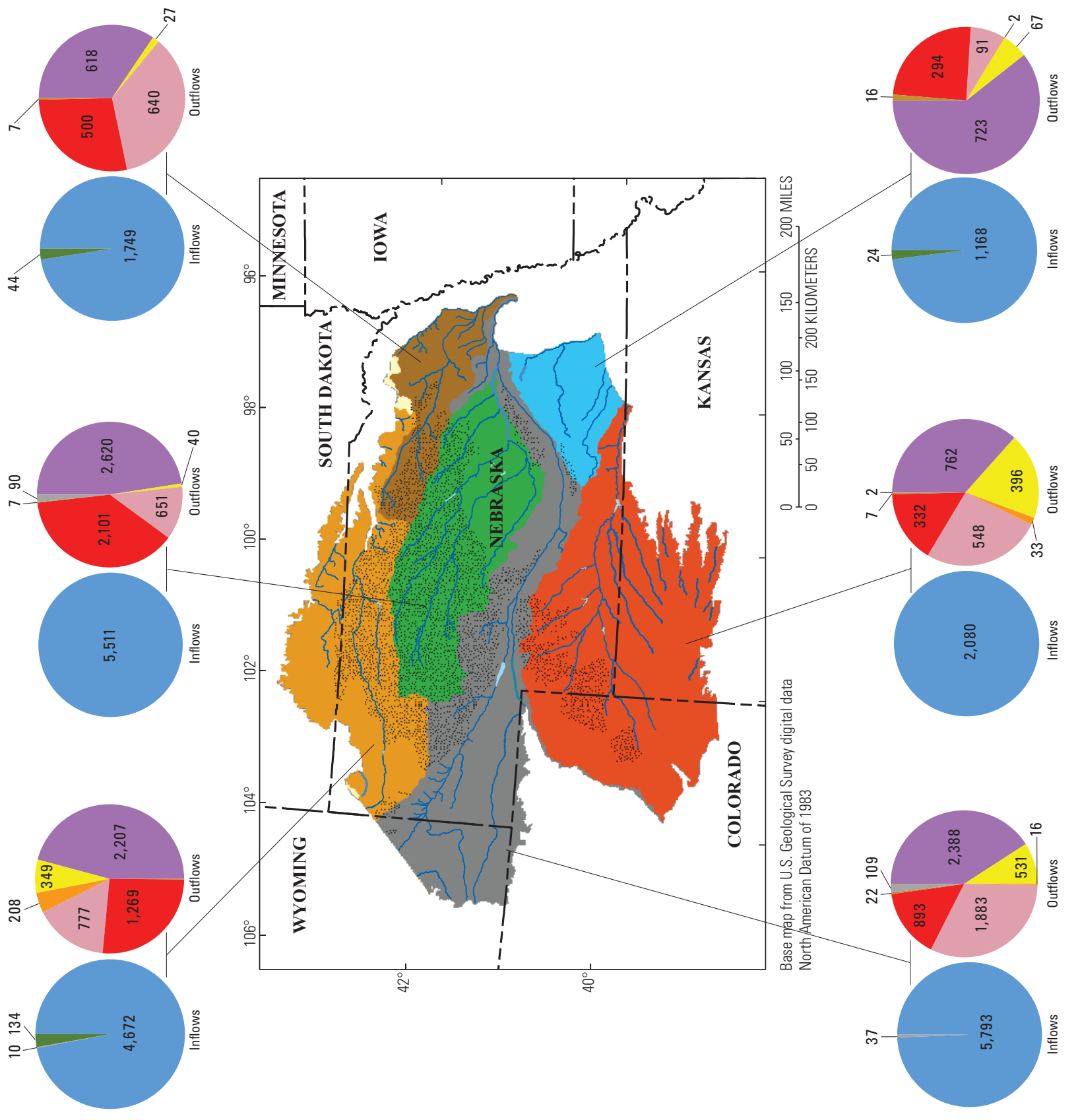

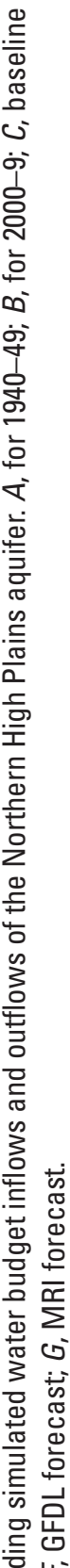

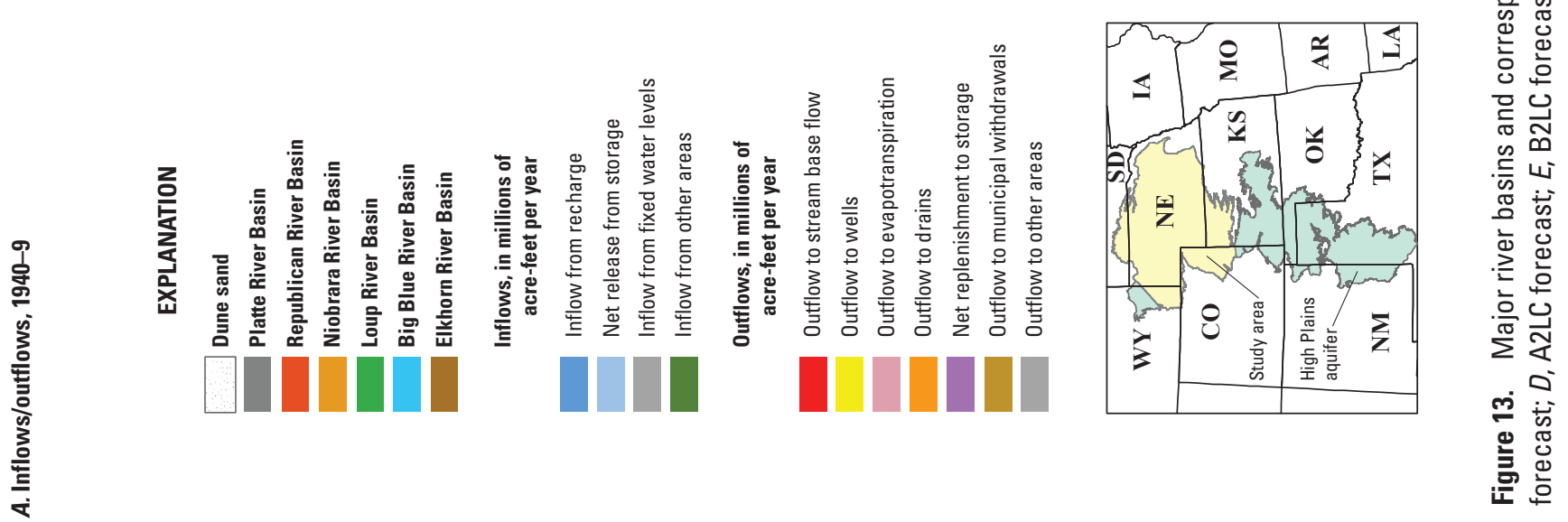




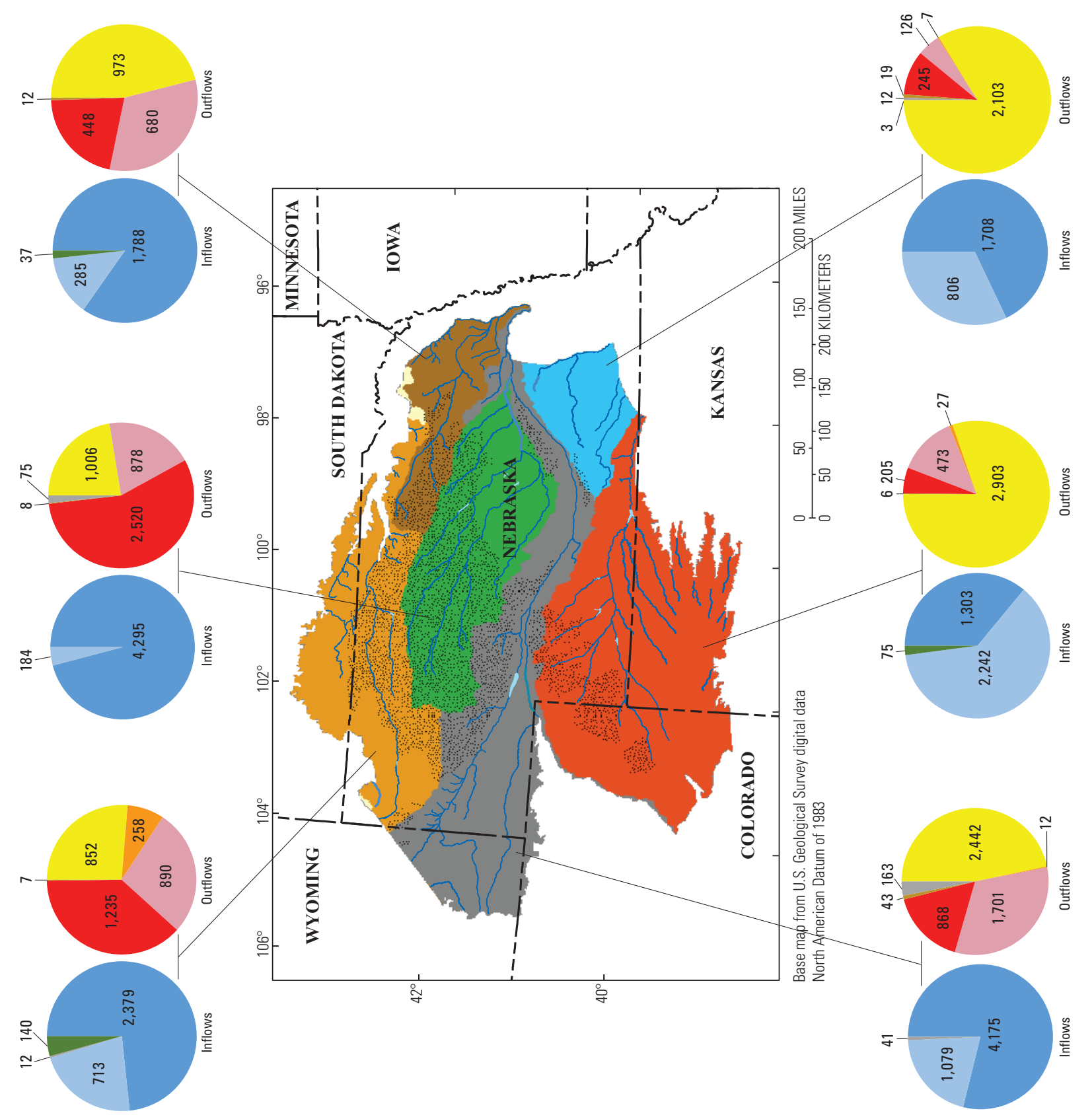

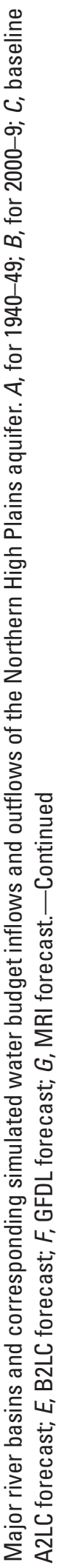

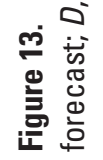




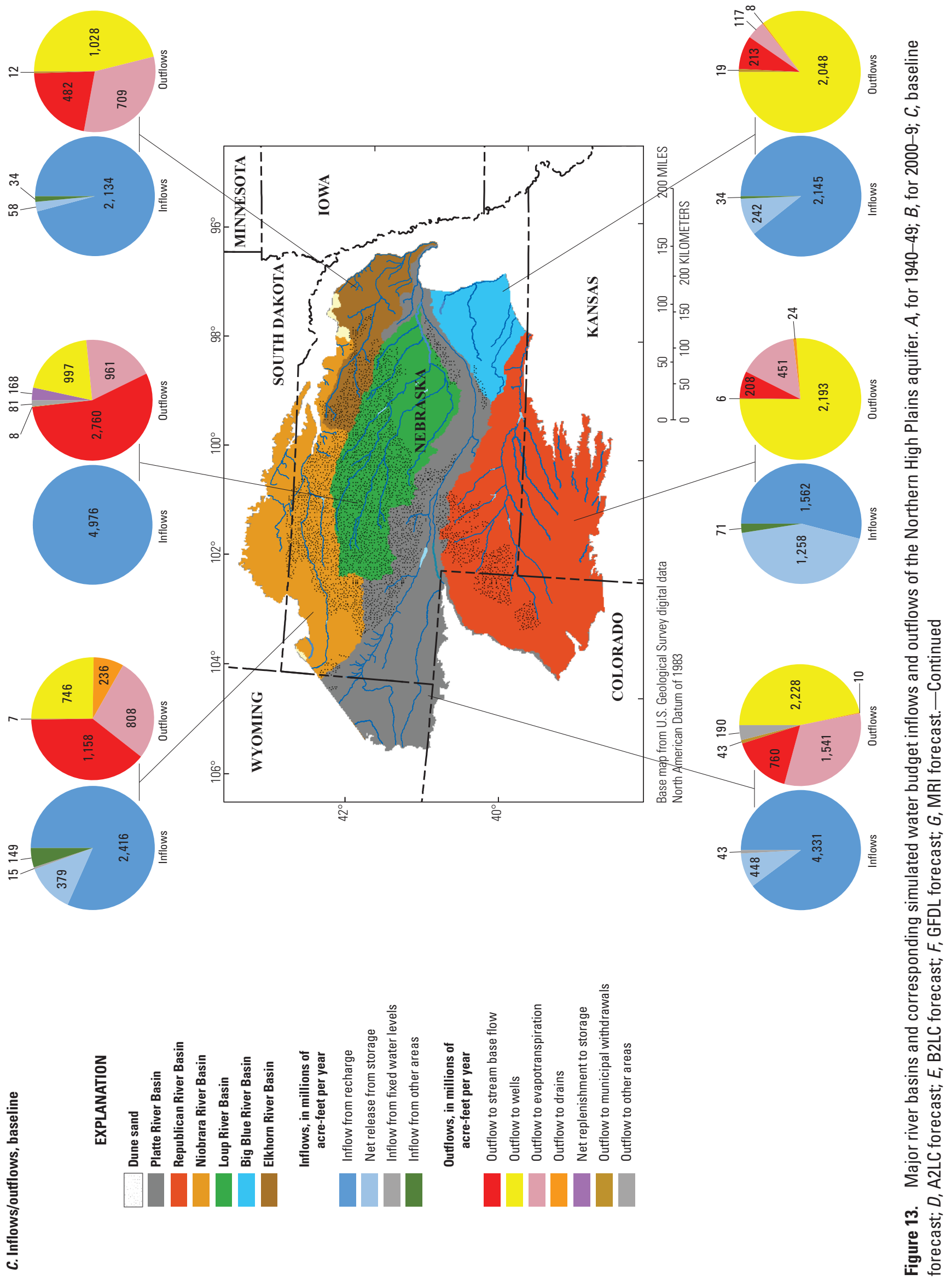




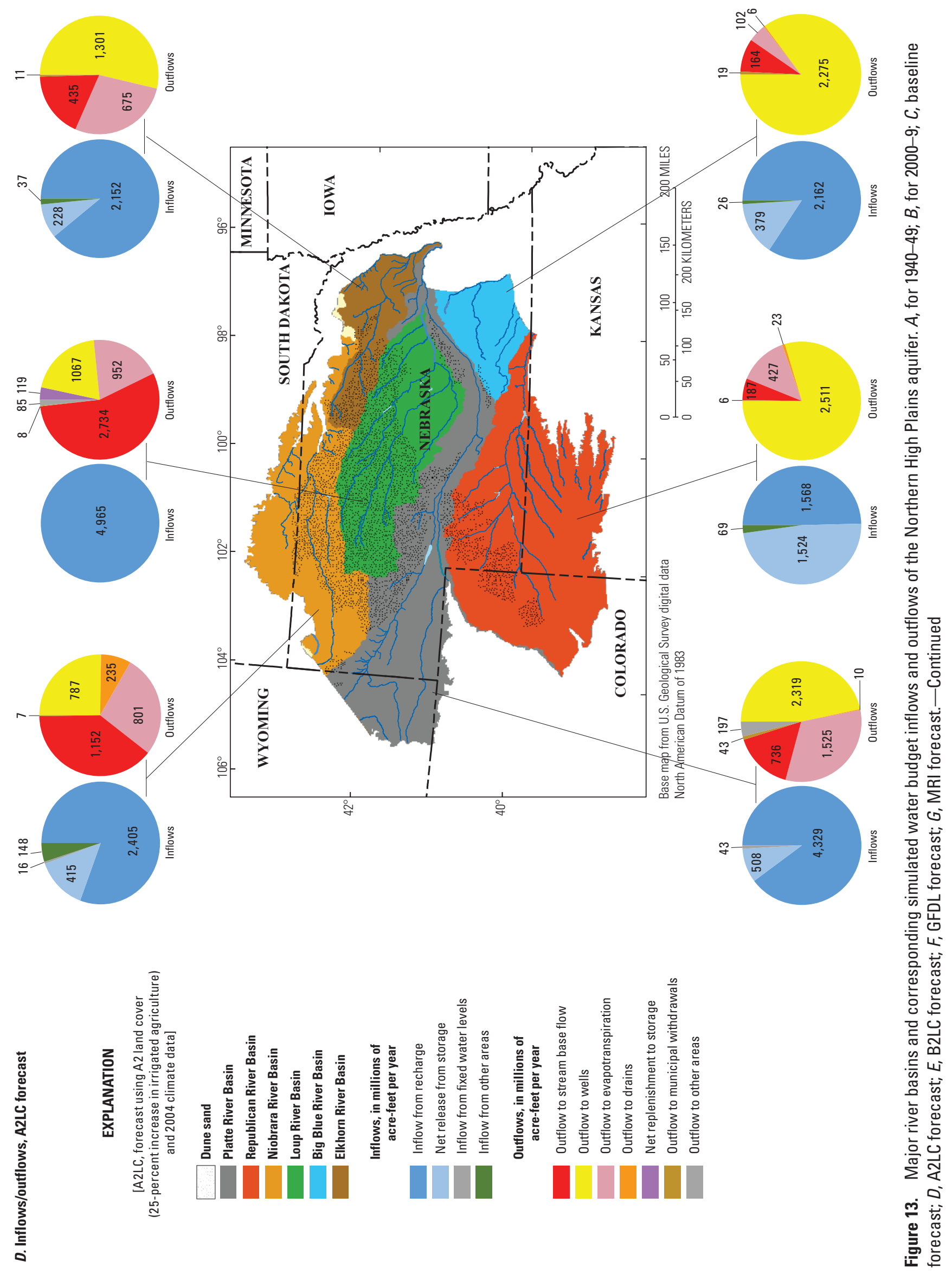




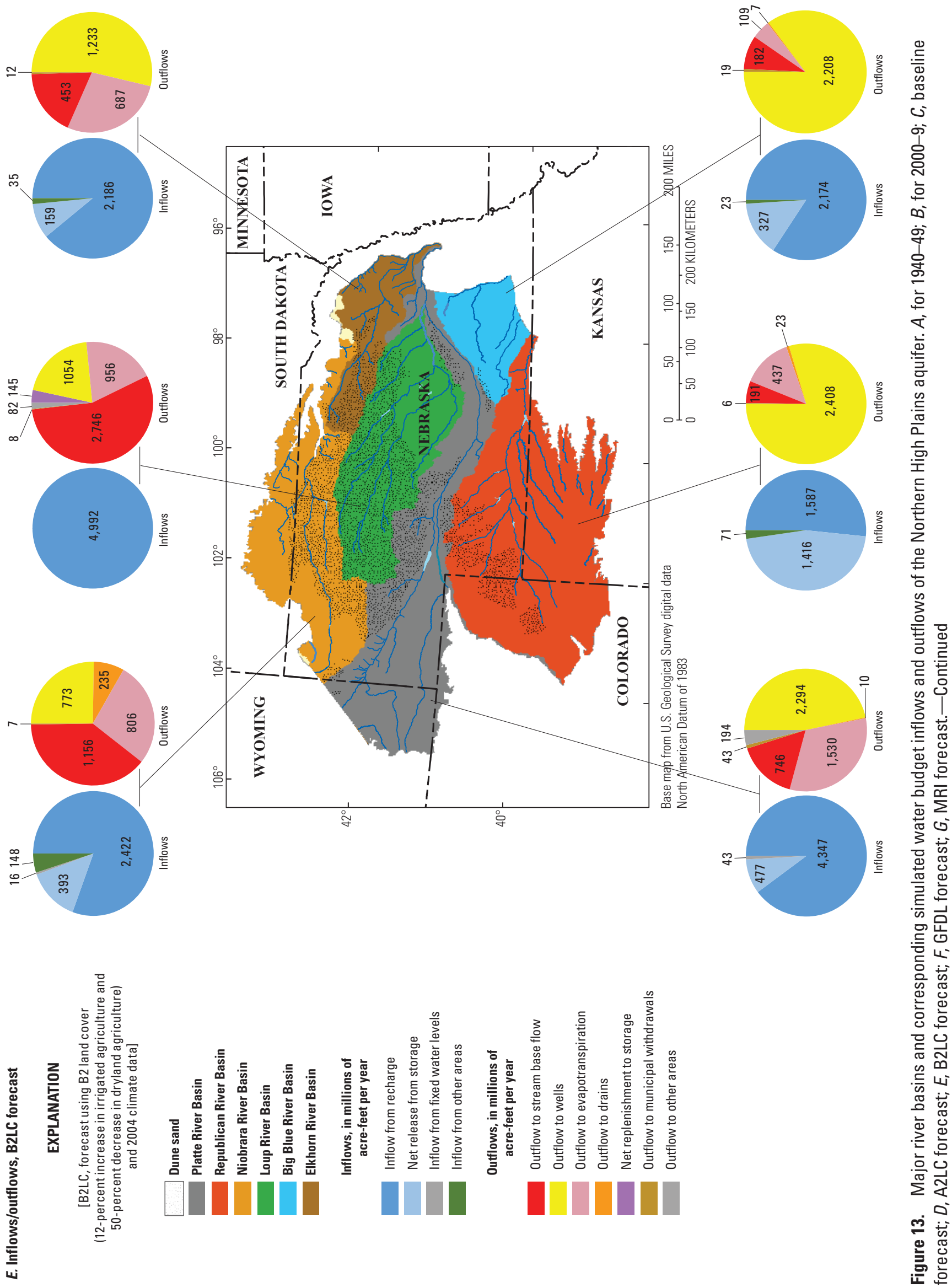




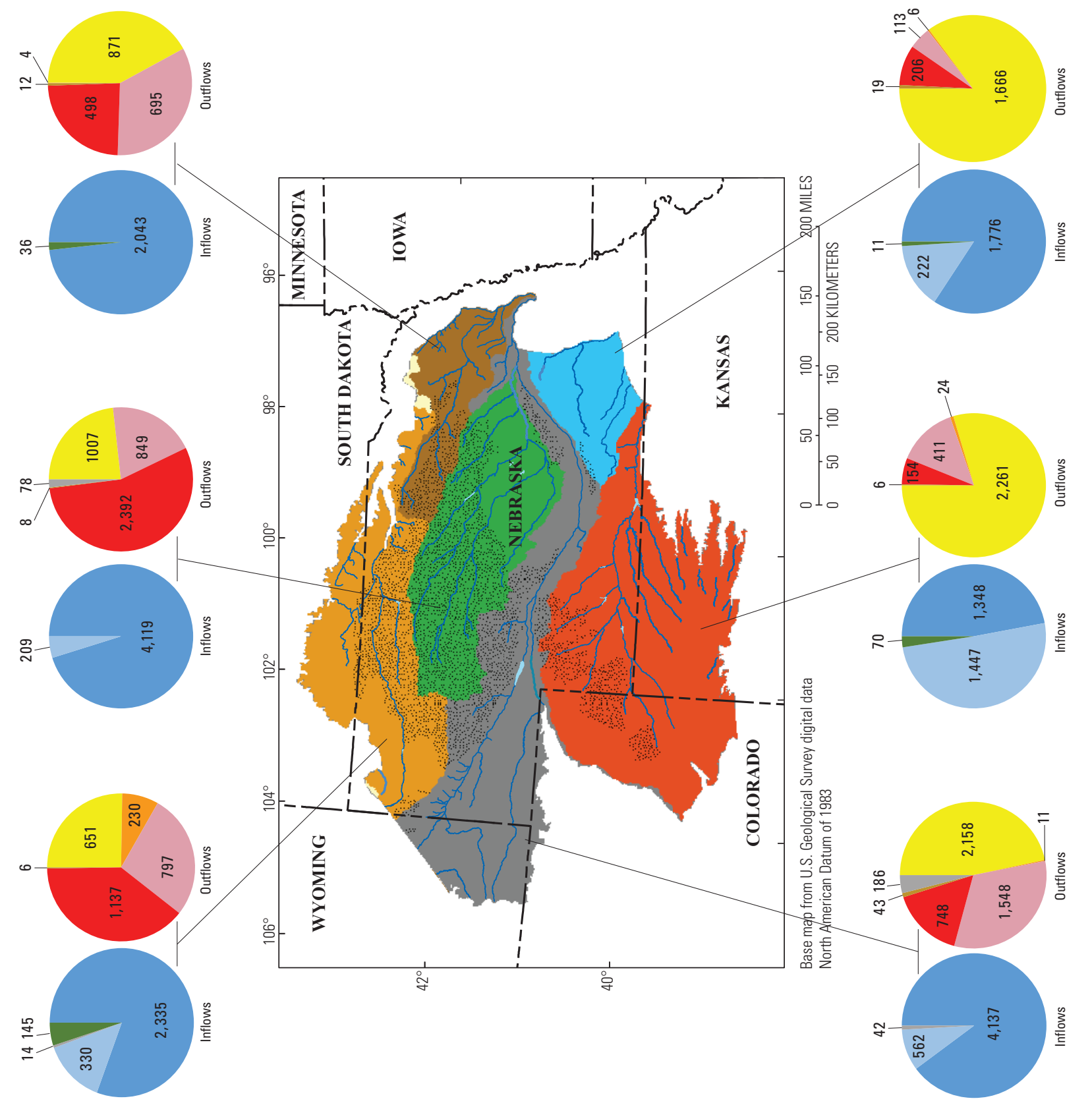

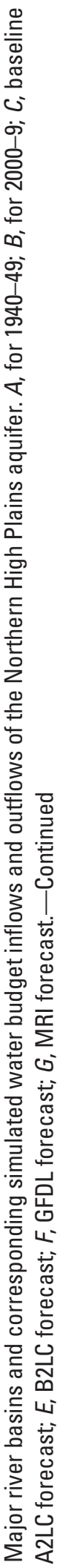

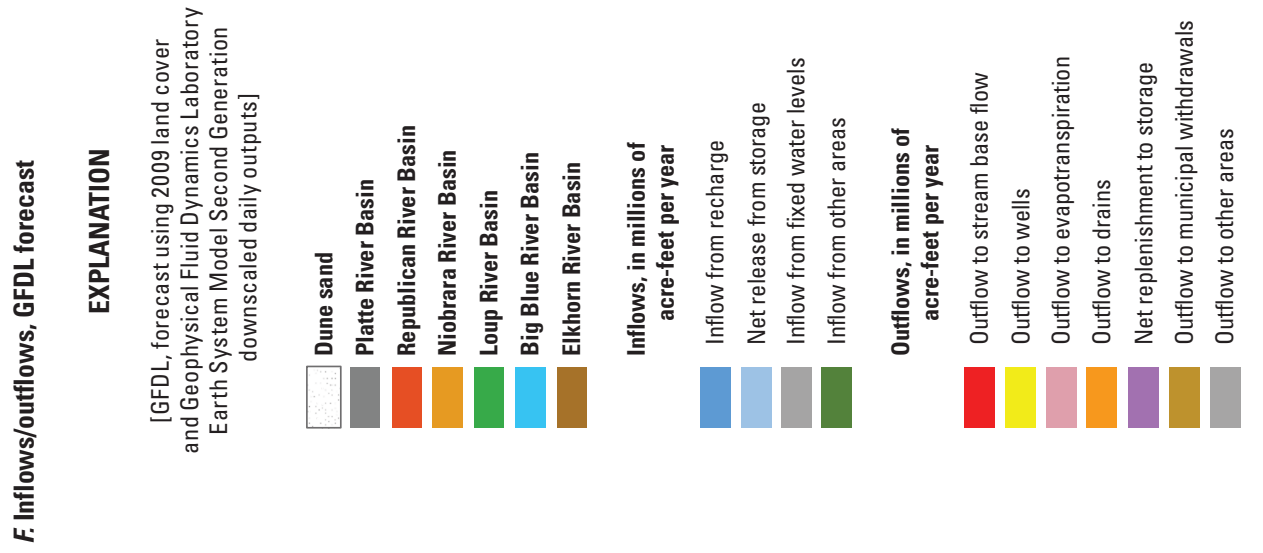

m 


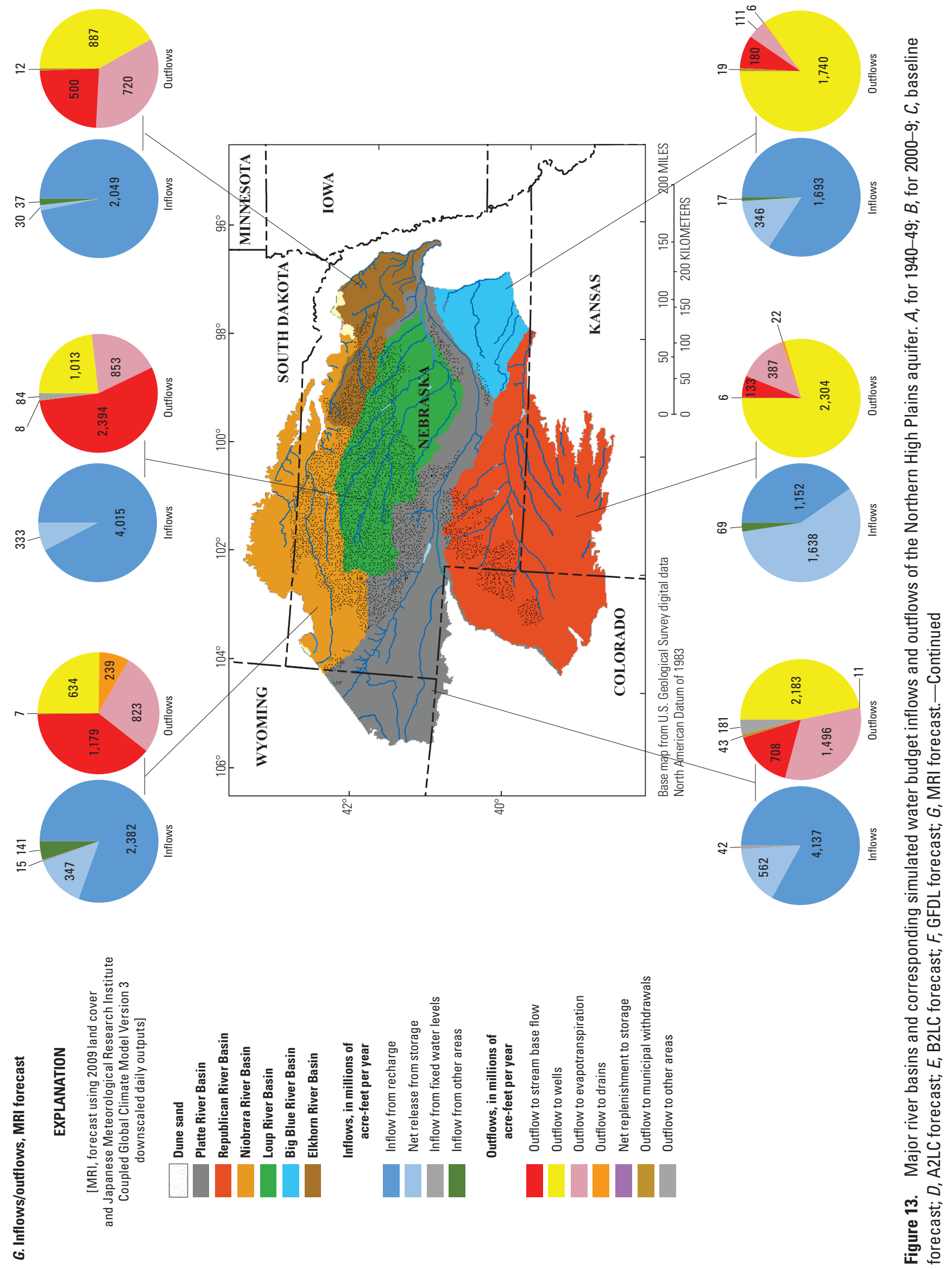


streams of the Northern High Plains aquifer. In these basins, losses to streams were also larger than to evapotranspiration.

Average 1940-49 simulated losses to irrigation wells were largest in the Platte and Republican River Basins but were still a small part of total groundwater leaving the aquifer system (losses). Just as for the Northern High Plains aquifer (fig. 12), every basin had simulated net replenishment to storage, corresponding to groundwater-level rises. Groundwaterlevel rises were caused in part by canal systems that were emplaced or expanded from 1940 to 1949; but because gains from canal seepage recharge were only 7 percent of aquifer gains, the remainder of the difference must be attributed to simulated 1940-49 recharge from precipitation being larger than that of preceding periods. Also, basin to basin groundwater flows were not a large part of basin water budgets (fig. $13 \mathrm{~A}$, labeled "inflow from other areas"). This means that the dominant processes affecting water budgets happened within the basins, not as groundwater flows to or from other basins.

\section{Postdevelopment Hydrologic System}

This section of the report describes the postdevelopment hydrologic system in terms of processes causing gains and losses to the groundwater system during major groundwater withdrawals for irrigation (2000-9). This section also describes the corresponding 2000-9 simulated water budget components of the calibrated Northern High Plains aquifer model (Peterson and others, 2016a) and differences in 2000-9 simulated groundwater budget components from 1940 to 1949 , for the Northern High Plains aquifer and across the six major stream basins.

\section{Postdevelopment Water Budgets and Changes from Predevelopment}

Average postdevelopment (2000-9) gains were dominated by recharge from precipitation (fig. $11 B$; table 3 ) though recharge was much smaller than for 1940-49. The decrease is assumed to have been caused primarily by differences in climate, because other factors controlling recharge were the same. A decrease in recharge agrees with Stanton and others (2011), who estimated decreased recharge for 2000-9 as compared with 1940-49, though to a lesser extent than reported here. Recharge from canal seepage was about the same for $2000-9$ as for $1940-49$, but the amount of land irrigated with surface water is nearly the same because most surface-water irrigation projects were developed by the 1940s.

The largest average 2000-9 outflow was to irrigation wells, followed by losses to streams and to evapotranspiration, and the largest single difference between 1940-49 and 2000-9 was the large increase in losses to irrigation wells (fig. 11B; table 3). Because this is a closed system and closed water budget, increases in an outflow (or loss) must be balanced by either increases in gains or decreases to other losses. In this case, increased losses to irrigation wells were largely balanced by the eradication of outflows to a net replenishment of aquifer storage, and further by the induction of gains from a net release from storage (fig. 12). Gains from a net release from storage, corresponding to water-level declines, were consequently larger than those from 1940 to 1949 ( 0 acre-ft/ yr), as well as being more persistent than any decade from 1949 to 1999 , and were 25 percent of the 2000-9 gains, though these were not uniformly distributed across the Northern High Plains aquifer. Average 2000-9 groundwater in storage was 2,428 million acre- $\mathrm{ft}$, or about 28 million acre- $\mathrm{ft}$ less than for 1940-49.

Differences among average 2000-9 simulated water budgets from basin to basin and from the Northern High Plains aquifer are driven by basin characteristics and corresponding hydrologic processes; for example, gains from recharge were the largest inflow at the aquifer scale, and for five of the six basins (but not the Republican River Basin; fig. 13B). Basins with the most gains from recharge (in descending order, Loup, Platte, and Niobrara River Basins) had the most simulated stream base flow. The Platte River Basin had the second most gain from recharge but the third most loss to streams, likely because losses to evapotranspiration in the Platte River Basin removed water that otherwise might have discharged to streams. Loss to evapotranspiration was the third largest aquifer-scale outflow, but was limited to areas of shallow water table, and was largest for the Platte River Basin. Readers are reminded that evapotranspiration can remove either soil moisture or groundwater, which exist in nature in a continuum in areas of shallow groundwater but are represented in this study by separate simulation models. Evapotranspiration results in this report are presented as simulated in the groundwater model and represent groundwater discharge. Soil moisture evapotranspiration was simulated with the SWB model (Peterson and others, 2020) and those discharges are not presented in this report.

The Republican River Basin 2000-9 gains from a net release from storage made up a larger part of the gains than for any other basin in the Northern High Plains and, at more than 2,200 cubic feet per second $\left(\mathrm{ft}^{3} / \mathrm{s}\right)$, net release from storage also was larger than that basin's 1940-49 average gain from recharge and was larger than the total groundwater losses of the Elkhorn River Basin for 2000-9 (fig. 13B). Further, this rate was nearly one-half of the net release from storage of the Northern High Plains aquifer (table 3). Groundwater levels declined across more of the Republican River Basin than in the rest of the Northern High Plains aquifer (McGuire, 2017), and simulated net release from storage corresponds to those declines. The Republican River Basin also had the largest loss to (irrigation) wells, followed by the Platte River, Big Blue River, and Elkhorn River Basins. Not surprisingly, the Big Blue River, Elkhorn River, Platte River, and Republican River Basins also contain the most irrigated land (fig. 5). The upper Republican River Basin in particular also has a large deficit between potential evapotranspiration and precipitation (fig. 4A). Though the average simulated 2000-9 losses to (irrigation) wells were the largest outflow of the Northern 
High Plains aquifer, they were not the largest loss in the Loup and Niobrara River Basins, because those basins contain fewer irrigated acres than other areas (fig. 5) and have a smaller deficit between precipitation and potential evapotranspiration.

The largest 2000-9 loss of the Loup and Niobrara River Basins was to streams (creating base flow; fig. 13B). Loss to streams was the second largest outflow of the Northern High Plains aquifer (fig. 11B), most of which was in the Loup and Niobrara River Basins rather than being spread uniformly across the aquifer. Average 2000-9 loss to streams in the Loup River Basin was nearly one-half the total loss to streams for the Northern High Plains aquifer (table 3). The Republican River Basin had the least 2000-9 loss to streams.

\section{Response of the Hydrologic System to Estimated Future Conditions}

As described in the "Future Forecasts" section, 2009-49 groundwater model outputs were evaluated for five future forecasts using recharge and groundwater withdrawals for irrigation estimated with the SWB model. This section of the report describes the data used to forecast future conditions, as well as response of the simulated groundwater system to the five alternative forecasts.

\section{Data Used to Forecast Future Conditions}

Data input to the SWB models for various future (200949) forecasts are described in this section. The inputs were selected to represent (1) a baseline forecast, with average climate and 2009 land cover; (2) two forecasts of alternate patterns of land cover representing different levels of expansion of groundwater irrigation; and (3) two forecasts representing alternative climate conditions, using climate data downscaled from a global climate model. As described in the "Future Forecasts" section, SWB outputs of recharge and groundwater withdrawals for irrigation were inputs to corresponding groundwater models, so changes to SWB inputs caused the differences in future forecasts.

\section{Soil-Water-Balance Model}

The Northern High Plains aquifer SWB model (Peterson and others, 2020) was used to estimate 2009-49 recharge from precipitation and groundwater withdrawals for irrigation for subsequent use in a corresponding groundwater model. Recharge from precipitation and groundwater withdrawals for irrigation were estimated for five 2009-49 forecasts: (1) a baseline forecast; (2) a land cover forecast referred to as $\mathrm{A} 2 \mathrm{LC}$; (3) a land cover forecast referred to as B2LC; (4) a climate forecast referred to as GFDL; and (5) a climate forecast referred to as MRI. The baseline forecast is meant to represent no change from the end of the calibration model (2009), the land cover forecasts were used to evaluate the effects of potential future land cover changes (in particular, changes in agricultural usage), and the climate forecasts were used to evaluate the effects of potentially different future climate. Readers are cautioned that there is no certainty that any of these future forecasts are necessarily a "true" future forecast, nor do they necessarily span the possible range of conditions in the future period. Rather, these forecasts are used to evaluate the sensitivity of the Northern High Plains aquifer, groundwater flows, and related stream base flows to potential changes in future conditions.

\section{Baseline Soil-Water-Balance Model}

For the baseline forecast, the SWB input land cover was held at the 2009 land cover used in Peterson and others (2016b). Input climate data consisting of precipitation, minimum temperature, and maximum temperature were taken from 2004 because precipitation from this year was nearly the same as the average of 1940-2009, based on an analysis of six weather stations from around the Northern High Plains aquifer (National Oceanic and Atmospheric Administration, 2010; fig. 1, table 4). Precipitation was considered the most important indicator of average climatic conditions because recharge and irrigation requirements are heavily dependent on the amount and timing of precipitation (Stanton and others, 2011). The average precipitation year (2004) was selected as the year from 2000 to 2009 that had annual precipitation closest to average annual 1940-2009 precipitation (table 4). The average difference between 2004 and average annual 1940-2009 precipitation of all the stations was less than 0.1 in. for all six stations, though individual station data indicate that 2004 was from about 2.6 in. wetter to about 3.1 in. drier than the 1940-2009 average (for Broken Bow, Nebr., and Scottsbluff, Nebr., respectively).

The 2009 land cover dataset was used for the baseline forecast. Estimating 2009-49 recharge and irrigation rates under 2009 land cover conditions represented no change in irrigated land or dry cropland, and provided a static repeating condition against which to compare alternative forecasts.

\section{Alternative Land Cover Soil-Water-Balance Models}

SWB land cover forecasts used two alternative land cover datasets, referred to as A2 land cover and B2 land cover (Houston and others, 2013), with the same climate data used in the baseline SWB forecast (precipitation, minimum temperature, and maximum temperature were taken from 2004). The A2 forecast land cover changes can be summarized as a substantial increase in irrigated agriculture, from 8.4 million acres in 2009 to 10.3 million acres in 2049 , primarily through increases in irrigated corn and irrigated soybeans (table 5). Dryland agriculture remained about the same throughout this time, though the mix changed slightly through decreases in dryland corn and soybeans and increases in dryland small grains. Grassland decreased by more than 3 million acres to accommodate the increase in irrigated agriculture. The B2 forecast land cover changes can be summarized as a more moderate increase in irrigated agriculture (than that of A2), 


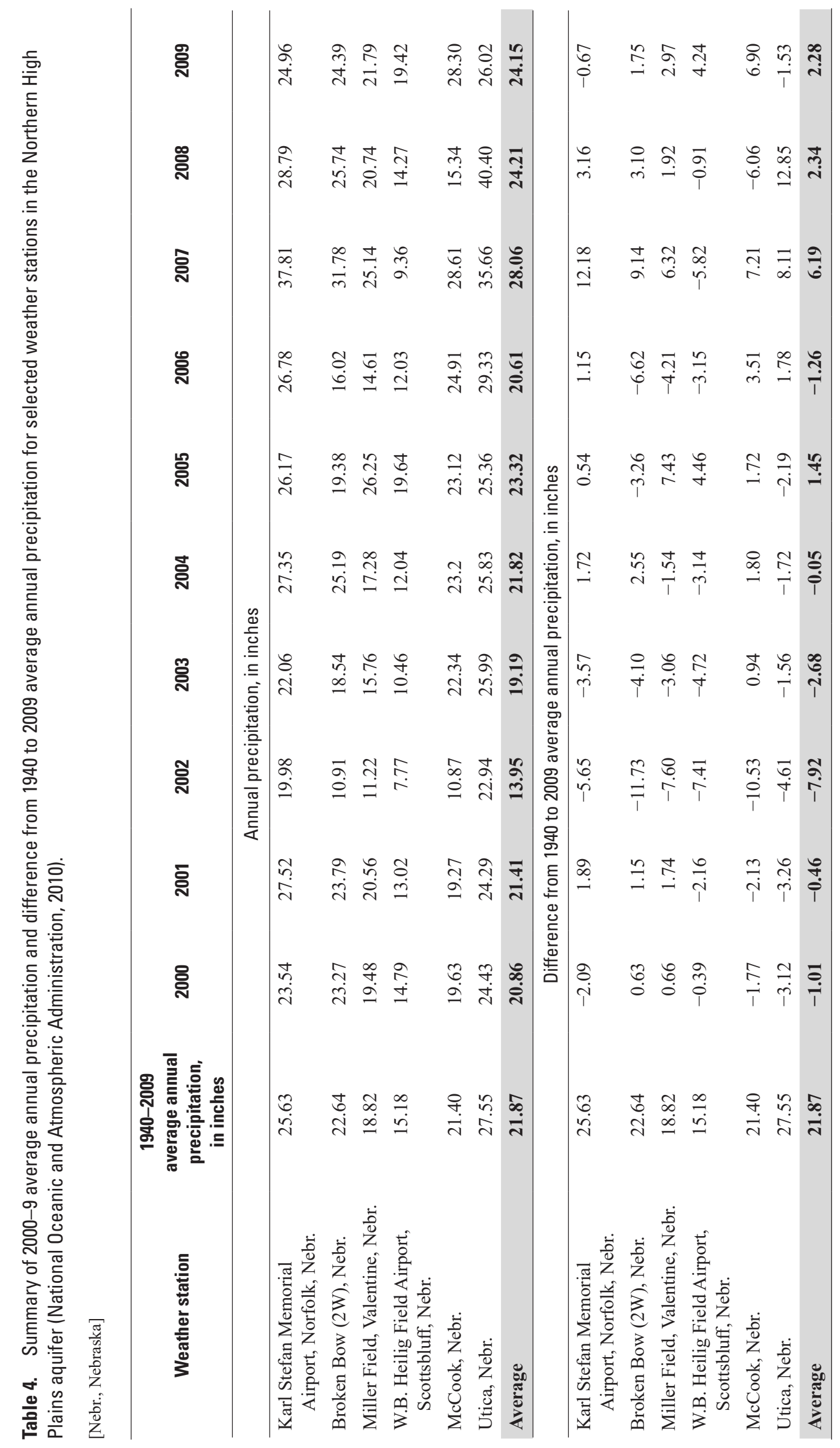


Table 5. Summary of land cover classification for the Northern High Plains aquifer Soil-Water-Balance (SWB) model for 2009 and 2049, for SWB models corresponding to the baseline, A2LC, and B2LC forecasts.

[A2LC, forecast using A2 land cover and 2004 climate data (purple in figures 12 and 14); B2LC, forecast using B2 land cover and 2004 climate data (green in figures 12 and 14)]

\begin{tabular}{|c|c|c|c|c|c|c|c|}
\hline \multirow{2}{*}{$\begin{array}{l}\text { Land cover } \\
\text { classification }\end{array}$} & \multirow{2}{*}{ Forecast } & \multicolumn{2}{|c|}{$\begin{array}{c}\text { Baseline, in millions of } \\
\text { acres }\end{array}$} & \multicolumn{2}{|c|}{ A2LC, in millions of acres } & \multicolumn{2}{|c|}{ B2LC, in millions of acres } \\
\hline & & 2008,2009 & 2049 & 2009 & 2049 & 2009 & 2049 \\
\hline \multirow[t]{5}{*}{ Irrigated } & Corn & 5.2 & 5.2 & 5.2 & 6.5 & 5.2 & 5.9 \\
\hline & Soybeans & 1.8 & 1.8 & 1.8 & 2.3 & 1.8 & 2.2 \\
\hline & Sorghum & 0.1 & 0.1 & 0.1 & 0.1 & 0.1 & 0.1 \\
\hline & Small grains & 0.8 & 0.8 & 0.8 & 0.8 & 0.8 & 0.8 \\
\hline & Alfalfa and hay & 0.5 & 0.5 & 0.5 & 0.6 & 0.5 & 0.5 \\
\hline \multirow[t]{5}{*}{ Dryland } & Corn & 3.1 & 3.1 & 3.1 & 2.9 & 3.0 & 1.2 \\
\hline & Soybeans & 1.2 & 1.2 & 1.2 & 1.0 & 1.2 & 0.7 \\
\hline & Sorghum & 0.5 & 0.5 & 0.5 & 0.5 & 0.5 & 0.4 \\
\hline & Small grains & 3.0 & 3.0 & 3.0 & 3.5 & 3.0 & 1.7 \\
\hline & Alfalfa and hay & 0.4 & 0.4 & 0.4 & 0.4 & 0.4 & 0.3 \\
\hline \multirow[t]{3}{*}{ Nonagricultural } & Developed & 2.2 & 2.2 & 2.2 & 2.9 & 2.2 & 2.4 \\
\hline & Grassland & 36.0 & 36.0 & 36.0 & 32.9 & 36.1 & 39.3 \\
\hline & Other & 4.7 & 4.7 & 4.7 & 5.1 & 4.7 & 4.0 \\
\hline \multicolumn{2}{|c|}{ Total agricultural, irrigated } & 8.4 & 8.4 & 8.4 & 10.3 & 8.4 & 9.5 \\
\hline \multicolumn{2}{|c|}{ Total agricultural, dryland } & 8.2 & 8.2 & 8.3 & 8.3 & 8.1 & 4.4 \\
\hline \multicolumn{2}{|c|}{ Total other land cover } & 42.9 & 42.9 & 42.8 & 40.9 & 43.0 & 45.7 \\
\hline
\end{tabular}

from 8.4 to 9.5 million acres from 2009 to 2049 , again primarily through increases in irrigated corn and soybeans. At the same time, B2 dryland agriculture decreased substantially, from 8.1 million acres in 2009 to 4.4 million acres in 2049, primarily through decreases to dryland corn, dryland small grains, and dryland soybeans, converted to grassland; therefore, grassland increased from 36.1 million acres in 2009 to 39.3 million acres in 2049.

Because the estimated land cover data from Houston and others (2013) did not distinguish irrigated from nonirrigated agricultural land, a separate process was applied to differentiate these lands. First, all lands classified as irrigated in 2008 from Peterson and others (2016b) were classified as irrigated in 2009, and any other agricultural lands were classified as nonirrigated. Second, various agencies such as the Nebraska Natural Resources Districts and the States of Colorado, South Dakota, Wyoming, and Kansas were contacted to determine if post-2009 expansion of irrigated lands would be allowed because some of these areas were subject to moratoriums or limits on additional irrigation wells or irrigated acres.

The Northern High Plains aquifer then was divided into 94 zones, correlated to the maximum amount of additional irrigated agricultural development allowed each year from 2009 to 2049. The A2 and B2 datasets for each year from 2009 to 2049 were evaluated to determine if the legally allowed irrigated agricultural areas were larger than those of A2 or B2, and if so, additional areas were reclassified as irrigated. The location of the reclassification was selected as the areas closest to those irrigated in 2008 on the assumption that areas closest to existing irrigation were the most likely to be developed. In some cases, legal restrictions on irrigated acres were meant to reduce or limit the number of irrigated acres in future years, and in these or any other cases where the A2 or B2 irrigated areas were larger than the legally allowed area, irrigated areas were reclassified as nonirrigated, again preferentially preserving the irrigated areas that were closest to 2008 irrigation.

Lastly, the A2 and B2 land cover data from Houston and others (2013) were generated at a different time than the 1950-2008 land cover data from Peterson and others (2016b), and the estimation method was slightly different. The different estimation methods resulted in an artificial mismatch between classifications for 2008 and 2009. The land cover data from Peterson and others (2016b) more closely resembled the legally allowed irrigated areas, and the transition to the less constrained 2009-49 data (Houston and others, 2013) created an abrupt and unrealistic shift in the land cover classification between 2008 and 2009. Therefore, the trends of annual land cover changes were extracted from the 2009-49 data described in the previous paragraph and applied successively to the 2008 land cover dataset (Peterson and others, 2016b), generating 
a new 2009-49 land cover dataset and eliminating the abrupt shift. The trends were applied to agricultural classifications and developed (or urban) parcels. Grassland is the dominant land cover of the Northern High Plains aquifer (table 5); therefore, proximity to existing classification was used to preferentially place "new" land covers on locations classified as grassland, closest to the previously existing land cover of the same type, combined with a random factor to prevent spatial bias when more than one location was equally close. When a particular land cover decreased, that cell was converted to grassland. The land cover data processed as described in the preceding paragraphs were used as the SWB inputs for the groundwater model forecasts referred to as A2LC and B2LC (Peterson and others, 2020).

\section{Alternative Climate Soil-Water-Balance Models}

Climate forecasts used two alternative sets of climate data with the same land cover as the baseline SWB forecast (the 2009 land cover used in Peterson and others [2016b]). Alternative climate data included precipitation and minimum and maximum temperature generated by two downscaled Earth System Models from the World Climate Research Programme's Coupled Model Intercomparison Project phase 5 (CMIP5) multimodel ensemble that couples global atmospheric circulation and oceanic circulation models (Taylor and others, 2012). The CMIP5 multimodel ensemble used four emissions scenarios called Representative Concentration Pathways (RCPs), named after their respective radiative forcing target levels for 2100 (as Watts per square meter [Watts $\left./ \mathrm{m}^{2}\right]$ ). The four scenarios are RCP2.6, RCP4.5, RCP6.0, and RCP8.5, each with an increased radiative forcing of 2.6, 4.5, 6.0, and 8.5 Watts $/ \mathrm{m}^{2}$, respectively. The RCPs are used to predict future climate under different greenhouse gas and air pollution emissions and land cover conditions. RCP2.6 simulates a peak in human emissions of greenhouse gases and decline by 2030 with the least amount of warming over the next century, whereas RCP8.5 predicts a steep increase in greenhouse gas emissions and, subsequently, the most extreme amount of warming over the next century. The Earth System Modelling (ESM) community of climate modeling teams from many agencies around the world downscale the CMIP5 multimodel ensemble General Circulation Model (GCM) outputs using two downscaling techniques: monthly bias correction with spatial disaggregation and daily bias correction with constructed analogs. Different downscaling methods for a specific RCP produce gridded climate projections of a finer grid resolution than the GCMs but tend to produce a wide range of results/projections. Based on this information, this study used two daily bias corrections with constructed analogs downscaled climate projections from the RCP6.0 scenario because it forecasts moderate warming and was not an extreme case. It was considered that using different downscaling versions of the same RCP scenario might provide insight on how forecasts of future groundwater availability might be affected by different GCM downscaling methods.
Climate forecast 1 used the National Oceanic and Atmospheric Administration Geophysical Fluid Dynamics Laboratory Earth System Model Second Generation downscaled daily outputs (referred to herein as the "GFDL forecast"; Bureau of Reclamation, 2013). Climate forecast 2 used the Japanese Meteorological Research Institute Coupled Global Climate Model Version 3 downscaled daily outputs (referred to herein as the "MRI forecast"; Bureau of Reclamation, 2013). The GFDL and MRI datasets were used because their June-JulyAugust (approximate growing season) average temperature and precipitation had the lowest average bias compared to observed 1979-2005 temperature and precipitation in central North America (Sheffield and others, 2013).

Average 2009-49 climate data for the GFDL forecast were slightly wetter and warmer than 2000-9 (table 6). The 2009-49 MRI forecast was slightly wetter and cooler than 2000-9. GFDL 2009-49 average precipitation was $0.04 \mathrm{in} /$ yr higher than the baseline, whereas MRI 2009-49 average precipitation was about $0.04 \mathrm{in} / \mathrm{yr}$ lower than the baseline. However, the timing of the precipitation also is important because precipitation that falls during the growing season (herein defined as May 1 through September 30) can be used consumptively by evapotranspiration, whereas precipitation that falls during the nongrowing season has a better chance of becoming recharge to the aquifer because, for most areas of the Northern High Plains aquifer, potential evapotranspiration is larger than precipitation (fig. $4 B, C$ ). GFDL average growing season precipitation was 0.79 in. larger than that of the baseline, meaning that for the GFDL data, 0.79 in. of precipitation was in effect retimed from the nongrowing season to the growing season as compared with the baseline (table 6). The MRI 2009-49 precipitation also included a redistribution of about $0.4 \mathrm{in}$. of precipitation from the nongrowing season into the growing season as compared with the baseline.

Increases in temperature also directly increase the rate of evapotranspiration (Allen and others, 1998). The GFDL 2009-49 average daily temperature was about $1^{\circ} \mathrm{F}$ higher than for the baseline (2009-49), whereas MRI 2009-49 average daily temperature was $0.16^{\circ} \mathrm{F}$ lower than for the baseline (table 6). As with precipitation, the time of year of the temperature changes also matters. Maximum growing season daily temperatures for $2009-49$ were $3.13^{\circ} \mathrm{F}$ higher than the baseline for GFDL and $2.09^{\circ} \mathrm{F}$ higher than the baseline for MRI. For GFDL, maximum nongrowing season daily temperatures for 2009-49 were $3.29^{\circ} \mathrm{F}$ higher than the baseline, and for MRI, were $1.21^{\circ} \mathrm{F}$ higher than the baseline. The average daily temperature of MRI is lower than the baseline and indicated the bias of that dataset towards lower temperatures, even though the average of the MRI minimum and maximum daily temperatures is larger than the baseline. The GFDL and MRI forecasts also include a warming trend from 2009 to 2049 that is not in the baseline temperature data taken from 2004 (used for 2009-49). 
Table 6. Summary of downscaled global climate model precipitation and temperature data used as inputs for the Northern High Plains aquifer Soil-Water-Balance model for 2009-49 for the baseline, GFDL, and MRI forecasts, compared with 2000-9 average measured data, and summary of corresponding output evapotranspiration, recharge, and irrigation requirements.

[GFDL, forecast using 2009 land cover and Geophysical Fluid Dynamics Laboratory Earth System Model Second Generation downscaled daily outputs (blue in figures 12 and 14); MRI, forecast using 2009 land cover and Japanese Meteorological Research Institute Coupled Global Climate Model Version 3 downscaled daily outputs (red in figures 12 and 14); in/yr, inch per year; in/season, inch per season; ${ }^{\circ} \mathrm{F}$, degrees Fahrenheit]

\begin{tabular}{|c|c|c|c|c|}
\hline \multirow{3}{*}{ Input/output } & \multirow{3}{*}{$\begin{array}{c}\text { Measured } \\
2000-9\end{array}$} & \multicolumn{3}{|c|}{ Forecast } \\
\hline & & Baseline & GFDL & MRI \\
\hline & & 2009-49 & 2009-49 & 2009-49 \\
\hline Average precipitation, in/yr & 21.10 & 21.28 & 21.32 & 21.24 \\
\hline $\begin{array}{l}\text { Average growing season } \\
\text { precipitation, in/season }\end{array}$ & 13.07 & 14.13 & 14.92 & 14.53 \\
\hline $\begin{array}{l}\text { Minimum growing season daily tem- } \\
\text { perature, }\left({ }^{\circ} \mathrm{F}\right)\end{array}$ & 54.45 & 53.19 & 54.80 & 54.40 \\
\hline $\begin{array}{l}\text { Minimum nongrowing season daily } \\
\text { temperature, }\left({ }^{\circ} \mathrm{F}\right)\end{array}$ & 24.11 & 23.25 & 24.91 & 23.98 \\
\hline $\begin{array}{l}\text { Maximum nongrowing season daily } \\
\text { temperature, }\left({ }^{\circ} \mathrm{F}\right)\end{array}$ & 50.78 & 48.92 & 52.21 & 50.13 \\
\hline \multicolumn{5}{|c|}{ Soil-Water-Balance model outputs } \\
\hline Average evapotranspiration, in/yr & 18.50 & 19.69 & 20.07 & 20.35 \\
\hline Average recharge, in/yr & 3.50 & 2.80 & 2.43 & 2.18 \\
\hline Average irrigation requirement, in/yr & 12.07 & 10.90 & 10.13 & 10.48 \\
\hline
\end{tabular}

\section{Groundwater-Flow Model}

The groundwater-flow model ending April 30, 2009 (Peterson and others, 2016b), was used as the initial model for the work described in this report. For the future forecasts, the model was revised to simulate May 1, 2009, to December 31,2049 , and is referred to hereafter as the "forecast model." The "forecast model" used the same model grid, configuration, and all calibrated model inputs as the initial model, except recharge and groundwater withdrawals for irrigation, for forecasts described later in this section. The seasonal temporal discretization was maintained, thereby each year of the "forecast model" also used an irrigation season from May 1 to September 30 each year as one stress period and a nonirrigation stress period from October 1 through April 30 of the following year. The only exception was that the last nonirrigation season, for 2049, was truncated to end on December 31 for simplicity in reporting, rather than covering the first 4 months of 2050. This approach to temporal discretization resulted in 82 stress periods representing May 2009 through December 2049.
For 2009-49, recharge and groundwater withdrawals for irrigation were estimated with the SWB model as described in the "Soil-Water-Balance Model" section, for forecasts referred to as the baseline, A2LC, B2LC, GFDL, and MRI. For each forecast, recharge and groundwater withdrawals for irrigation estimated with SWB were input to the 2009-49 groundwater model. Recharge was modified using calibration factors and addends after Peterson and others (2016a) and was summed with the canal seepage recharge from 2004 (identified as an "average year" as described in the "Soil-Water-Balance Model" section). Municipal groundwater withdrawals were similarly set at the 2004 rates. Only one instream reservoir (Lake McConaughy; fig. 1) was simulated directly in the 1940-2009 groundwater model, and reservoir releases for the forecast period (2009-49) were held at the 2004 rates documented in Peterson and others (2016b).

Primary model outputs evaluated across forecasts included aquifer-scale simulated water budgets, and basinscale simulated water budgets, for the six major stream basins of the Northern High Plains aquifer: the Niobrara River Basin, 
the Loup River Basin, the Elkhorn River Basin, the Platte River Basin, the Republican River Basin, and the Big Blue River Basin (fig. 1). River basin extents are mostly constant over time and are expected to be more familiar to readers of this report and, therefore, were used as boundaries to summarize model results for the same six major basins of the Northern High Plains aquifer. River basins also were considered more useful for summarizing than groundwater basins because the latter are less familiar or perhaps unknown to some readers; further, groundwater basins can expand, contract, or change shape, depending on the balance and distribution of inflows and outflows (also referred to as gains and losses), such as recharge and groundwater losses to streams or wells.

Results for the baseline forecast were characterized first by describing the water budget of the Northern High Plains area averaged across the forecast period (2009-49) and comparing that budget to what was simulated for the postdevelopment (2000-9) aquifer-scale simulated water budgets to examine the effects of conditions different from 2000-9. Basin-scale simulated water budgets were compared to the aquifer-scale simulated water budgets and against other basins to examine basins that differ from the aquifer-scale conditions, or basins that contributed a predominant part of aquifer-scale flows of a certain term. Subsequent forecasts were compared against the baseline forecast to isolate the effects of specific anthropogenic or climate data input changes on the groundwater system.

Streamflows are a critical indicator of groundwater availability because shortages in streamflow can trigger conjunctive (surface-water and groundwater) management actions (Nebraska Department of Natural Resources, 2004). Simulated stream base flow passing the downstream-most streamgage was evaluated for five of the six major streams of the Northern High Plains aquifer: the Niobrara River near Norden, Nebr. (USGS streamgage 06462000); the Loup River at Columbus, Nebr. (USGS streamgage 06794500); the Elkhorn River at Waterloo, Nebr. (USGS streamgage 06800500); the Republican River near Hardy, Nebr. (USGS streamgage 06853500); and the Big Blue River near Crete, Nebr. (USGS streamgage 06881000) (figs. 1, 14A-E). Simulated base flows at the downstream end of the major basins represent an integrated measure of all the upstream simulated flows and are another demonstration of the effects of basin- and aquiferscale simulated flows. Simulated average 2040-49 stream base flows for each forecast were compared to the average 2000-9 simulated base flows (fig. 14A-E; Peterson and others, 2016a), and against 2040-49 baseline forecast base flows, to indicate the effect of the alternate conditions represented in the forecast on the stream. Simulated 2040-49 base flows at the streamgages could be different from the average forecast

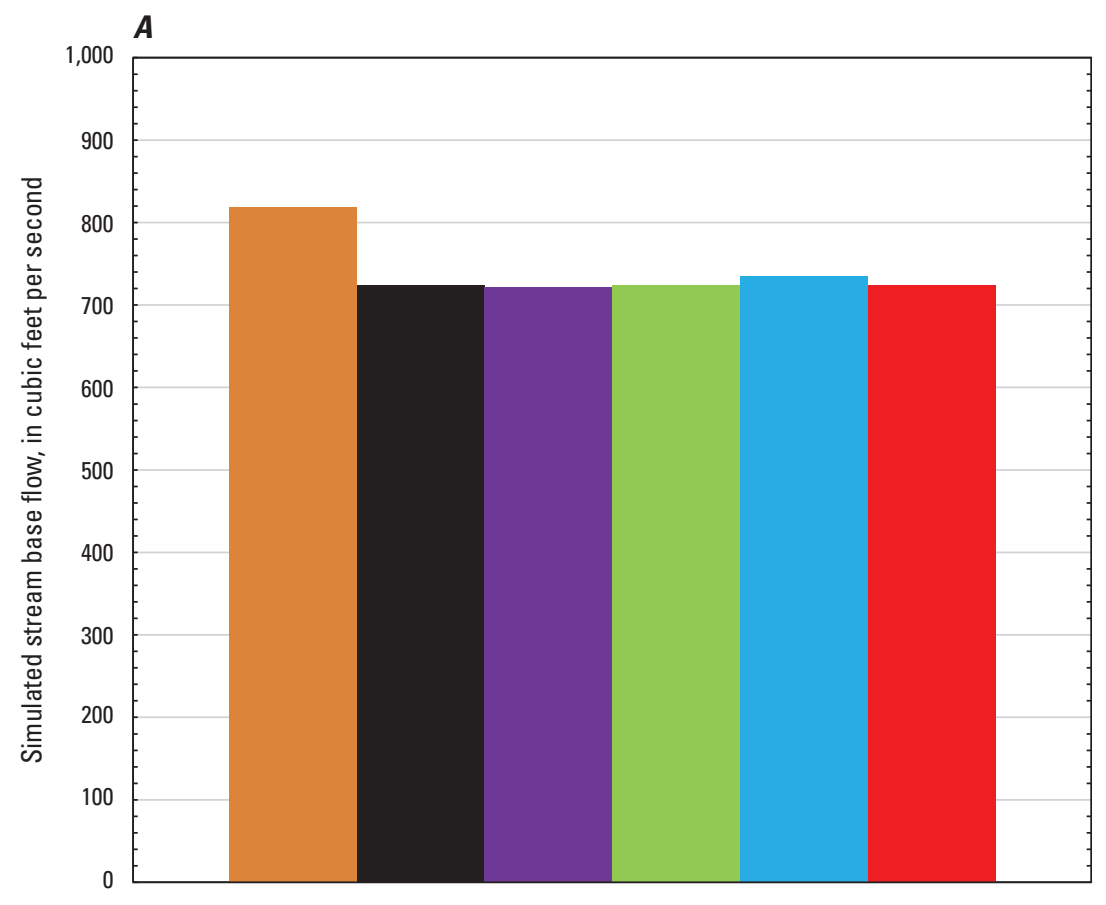

\section{EXPLANATION}

[A2LC, forecast using A2 land cover and 2004 climate data; B2LC, forecast using B2 land cover and 2004 climate data; GFDL, forecast using 2009 land cover and Geophysical Fluid Dynamics Laboratory Earth System Model Second Generation downscaled daily outputs; MRI, forecast using 2009 land cover and Japanese Meteorological Research Institute Coupled Global Climate Model Version 3 downscaled daily outputs]

\section{Average 2000-9}

Average 2040-49, for the forecast

Baseline

A2LC

B2LC

GFDL

MRI

Niobrara River near Norden, Nebraska (06462000)

Figure 14. Average simulated 2000-9 base flow (Peterson and others, 2016b), and average 2040-49 simulated base flow, for the baseline, GFDL, MRI, A2LC, and B2LC forecasts. The baseline used 2004 climate data and 2009 land cover inputs, and the A2LC and B2LC forecasts used A2 land cover and B2 land cover data (modified from Houston and others, 2013). $A$, Niobrara River near Norden, Nebraska (06462000); B, Loup River at Columbus, Nebraska (06794500); C, Elkhorn River at Waterloo, Nebraska (06800500); $D$, Republican River near Hardy, Nebraska (06853500); E, Big Blue River near Crete, Nebraska (06881000). 


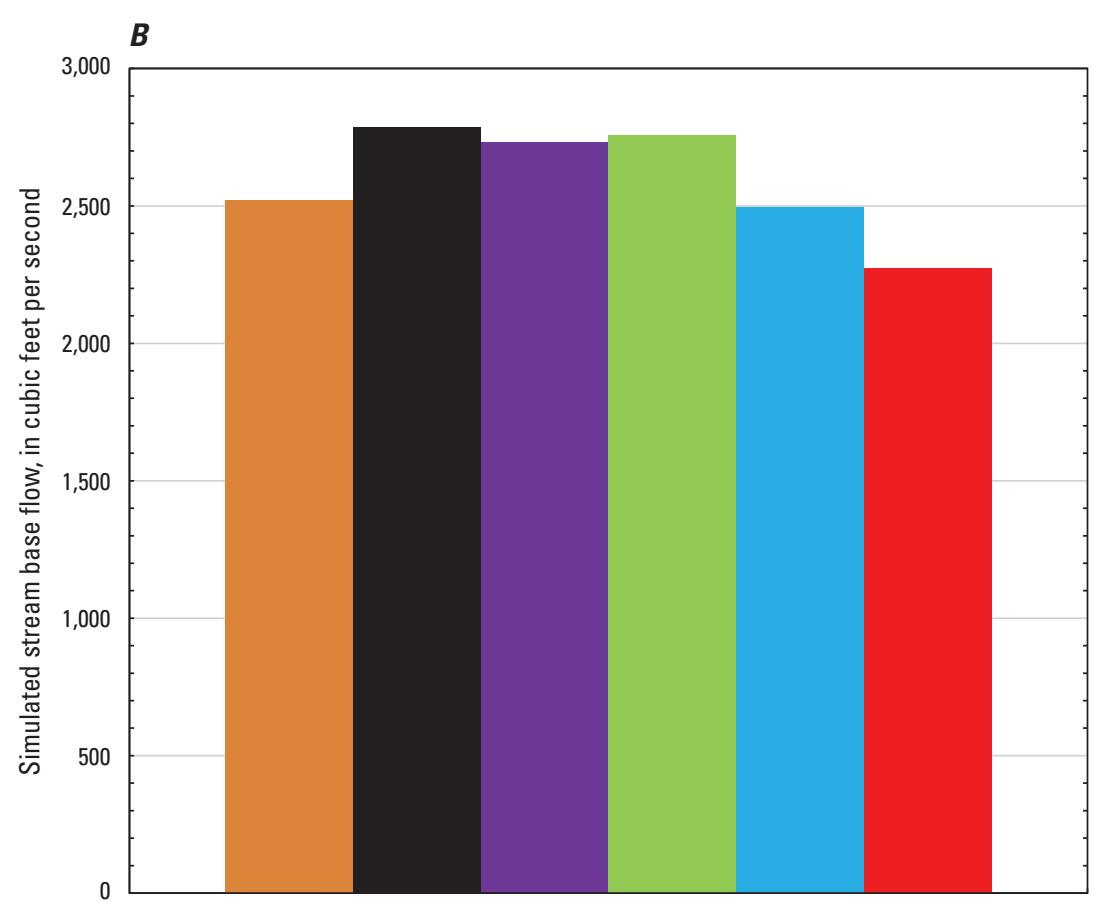

Loup River at Columbus, Nebraska (06794500)

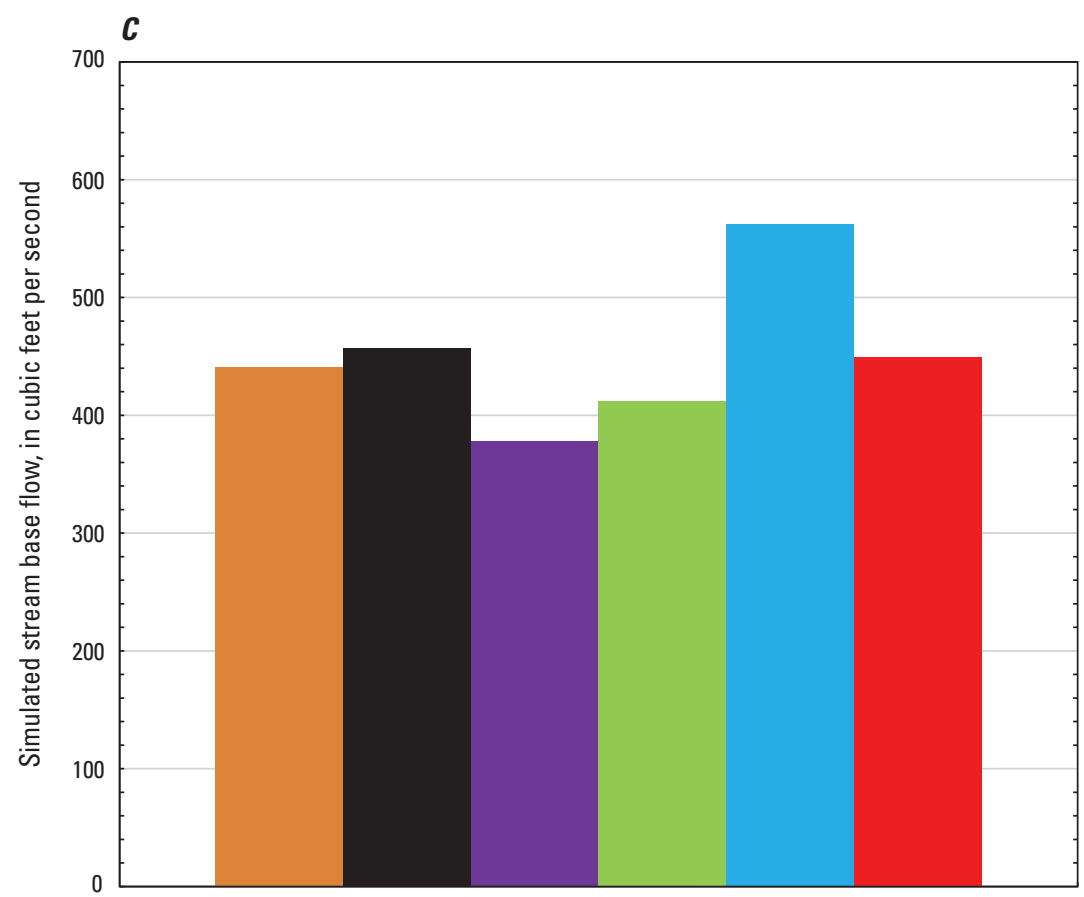

Elkhorn River at Waterloo, Nebraska (06800500)

\section{EXPLANATION}

[A2LC, forecast using A2 land cover and 2004 climate data; B2LC, forecast using B2 land cover and 2004 climate data; GFDL, forecast using 2009 land cover and Geophysical Fluid Dynamics

Laboratory Earth System Model Second

Generation downscaled daily outputs; MRI, forecast using 2009 land cover and Japanese

Meteorological Research Institute Coupled Global

Climate Model Version 3 downscaled daily outputs]

Average 2000-9

Average $2040-49$, for the forecast

Baseline

a $\quad$ 2LC

B2LC

GFDL

MRI

\section{EXPLANATION}

[A2LC, forecast using A2 land cover and 2004 climate data; B2LC, forecast using B2 land cover and 2004 climate data; GFDL, forecast using 2009 land cover and Geophysical Fluid Dynamics Laboratory Earth System Model Second Generation downscaled daily outputs; MRI, forecast using 2009 land cover and Japanese Meteorological Research Institute Coupled Global Climate Model Version 3 downscaled daily outputs]

Average 2000-9

Average 2040-49, for the forecast

Baseline

A2LC

B2LC

GFDL

MRI

Figure 14. Average simulated 2000-9 base flow (Peterson and others, 2016b), and average 2040-49 simulated base flow, for the baseline, GFDL, MRI, A2LC, and B2LC forecasts. The baseline used 2004 climate data and 2009 land cover inputs, and the A2LC and B2LC forecasts used A2 land cover and B2 land cover data (modified from Houston and others, 2013). $A$, Niobrara River near Norden, Nebraska (06462000); B, Loup River at Columbus, Nebraska (06794500); C, Elkhorn River at Waterloo, Nebraska (06800500); $D$, Republican River near Hardy, Nebraska (06853500); E, Big Blue River near Crete, Nebraska (06881000)._Continued 


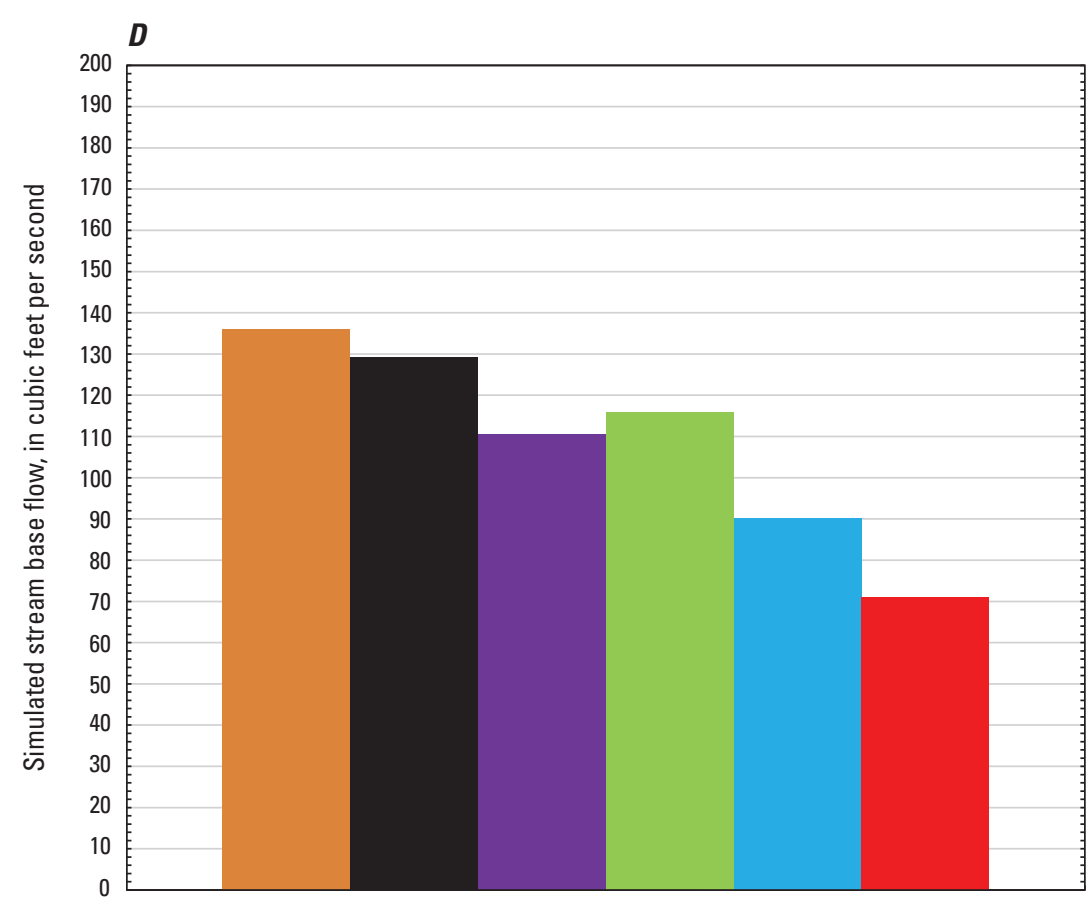

Republican River near Hardy, Nebraska (06853500)

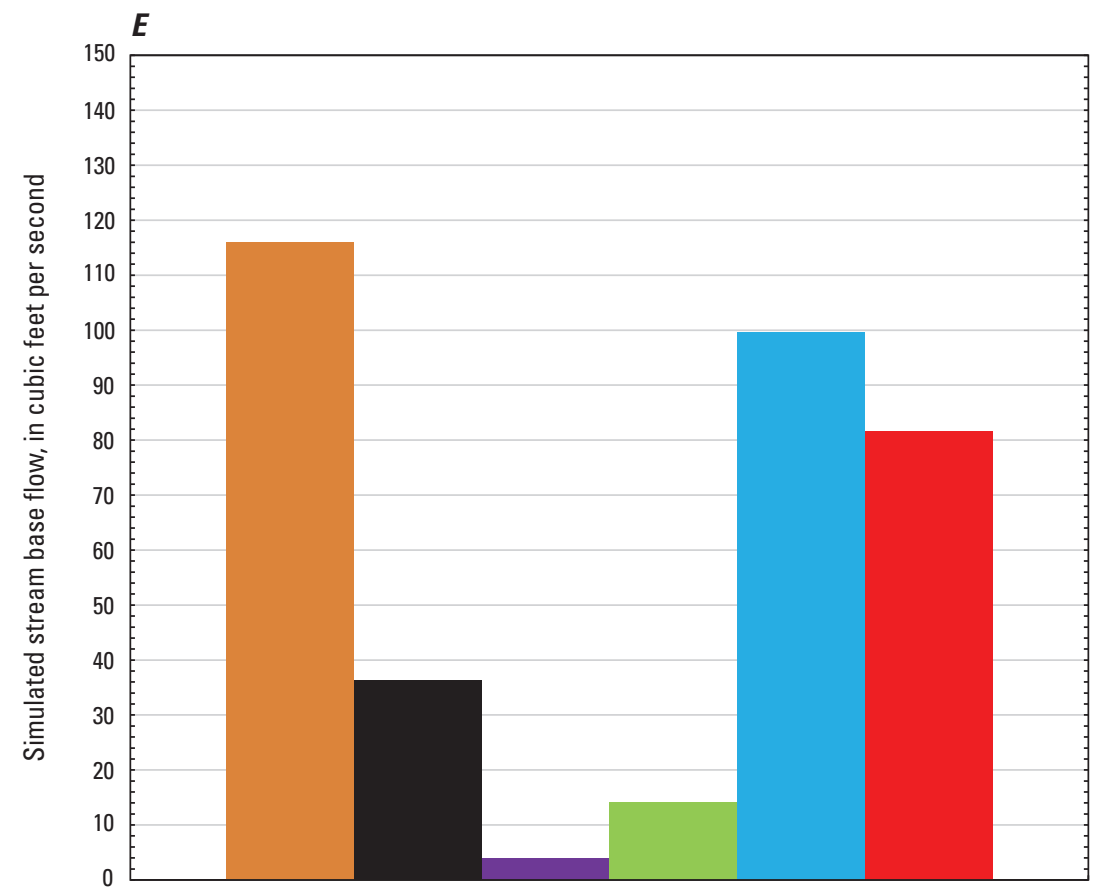

Big Blue River near Crete, Nebraska (06881000)

\section{EXPLANATION}

[A2LC, forecast using A2 land cover and 2004 climate data; B2LC, forecast using B2 land cover and 2004 climate data; GFDL, forecast using 2009 land cover and Geophysical Fluid Dynamics Laboratory Earth System Model Second Generation downscaled daily outputs; MRI, forecast using 2009 land cover and Japanese Meteorological Research Institute Coupled Global Climate Model Version 3 downscaled daily outputs]

Average 2000-9
Average 2040-49, for the forecast
Baseline
A2LC
B2LC
GFDL
MRI

\section{EXPLANATION}

[A2LC, forecast using A2 land cover and 2004 climate data; B2LC, forecast using B2 land cover and 2004 climate data; GFDL, forecast using 2009 land cover and Geophysical Fluid Dynamics Laboratory Earth System Model Second Generation downscaled daily outputs; MRI, forecast using 2009 land cover and Japanese Meteorological Research Institute Coupled Global Climate Model Version 3 downscaled daily outputs]

Average 2000-9

Average 2040-49, for the forecast

Baseline
A2LC
B2LC
GFDL
MRI

Figure 14. Average simulated 2000-9 base flow (Peterson and others, 2016b), and average 2040-49 simulated base flow, for the baseline, GFDL, MRI, A2LC, and B2LC forecasts. The baseline used 2004 climate data and 2009 land cover inputs, and the A2LC and B2LC forecasts used A2 land cover and B2 land cover data (modified from Houston and others, 2013). $A$, Niobrara River near Norden, Nebraska (06462000); B, Loup River at Columbus, Nebraska (06794500); C, Elkhorn River at Waterloo, Nebraska (06800500); $D$, Republican River near Hardy, Nebraska (06853500); E, Big Blue River near Crete, Nebraska (06881000).-Continued 
period (2009-49) base flows of the basin because of the difference in the averaged period, or if there were streams within the basin that were not tributaries to the stream being measured at the streamgage. Stream base flow was not evaluated for the Platte River Basin because of the effect of 2004 Lake McConaughy (fig. 1) reservoir release rates on the Platte River simulated stream base flow.

Readers are cautioned that forecast base flows and groundwater budgets included in these analyses are not comprehensive and may not be the average nor span the range of effects caused by potential future climate or land cover changes. These forecasts are provided as examples of how the groundwater-flow model can be used as a tool to evaluate aquifer and stream base flow responses to potential future conditions, such as different land cover or different climate. Forecast models generated during this study are available as a USGS data release (Peterson and others, 2020). Altering input data, such as selecting a different year from 2004 to provide average climate data inputs for three of the forecasts, likely would generate different results.

\section{Baseline Forecast}

Differences in simulated groundwater-flow terms between the baseline forecast and 2000-9 simulated conditions are directly attributable to climate because that was the only different input. Average baseline forecast flows among components were similar to that of 2000-9 (fig. 11B,C); the largest gains were of recharge from precipitation and the largest losses (or outflows) were to irrigation wells. However, the balance of the flows was different. For instance, baseline forecast gains of recharge from precipitation were, on average, about 1.4 million acre-feet per year (acre-ft/yr) larger than for 2000-9, and losses to irrigation wells were 0.8 million acre-ft/ yr smaller. As a result, baseline groundwater-level declines (gains from net release from storage) were 2.3 million acre-ft/ yr smaller than for 2000-9. In other words, groundwater levels declined more slowly for the baseline forecast than during 2000-9. This is because the average precipitation used in the baseline forecast was larger than actual precipitation from 2000 to 2009, leading to the increased recharge from precipitation and decreased losses to irrigation wells; less water needed to be withdrawn to meet crop needs. However, the baseline forecast net release from storage still indicates average declining groundwater levels of the aquifer at 1.6 million acre-ft/yr; hence, the amount of water in storage at the end of the baseline forecast (2049) was 56 million acre-ft less than the 2000-9 average. In addition, the rate at which groundwater was released from storage declined from 2009 to 2049 (fig. 12), indicating that the aquifer was moving toward equilibrium with the stresses imposed in the baseline forecast.

Baseline forecast simulated gains and losses were not distributed uniformly among basins of the Northern High Plains aquifer but were distributed proportionately in the same way as for 2000-9 (fig. 13B, C). For example, for 2000-9 and the baseline forecast, recharge from precipitation was largest in the Loup and Platte River Basins and smallest for the Republican River Basin. Baseline forecast recharge was larger for the aquifer and in every basin than it was for 2000-9, correlating with the average climate inputs that represented wetter conditions than 2000-9. Wetter conditions also resulted in baseline forecast losses to irrigation wells being smaller than for 2000-9 for five of the six basins, other than the Elkhorn River Basin. Because gains from recharge increased but losses to irrigation wells also increased, more precipitation fell in the Elkhorn River Basin during the nongrowing season in the baseline forecast than for 2000-9. The increase in Elkhorn River Basin baseline forecast recharge above the amount gained in 2000-9 was more than sufficient to balance the increase in losses to wells, and also to increase base flow slightly, and to reduce the rate of water-level decline (net release from storage) from 285 to $58 \mathrm{ft}^{3} / \mathrm{s}$. Gains from a net release from storage were largest in the Republican River Basin, which is the same as for 2000-9, followed by the Platte River Basin and Big Blue River Basin, corresponding to the areas where the deficit between precipitation and potential evapotranspiration is largest (fig. $4 A$ ).

Also, though Northern High Plains aquifer losses to streams were the same for 2000-9 and the baseline forecast, the contributions of each basin were different (figs. $13 B-C$ and $14 A-E$ ); for example, baseline forecast losses to streams in the Loup River Basin were $240 \mathrm{ft}^{3} / \mathrm{s}$ larger than for 2000-9 but were smaller in the Platte River, Niobrara River, and Big Blue River Basins. Baseline forecast losses to streams were only slightly larger than for 2000-9 for the Elkhorn River Basin and were about the same for the Republican River Basin. Simulated base flow declined the most (relative to 2000-9) for the Big Blue River near Crete, Nebr. (USGS streamgage 06881000), where the baseline forecast 2040-49 stream base flow was about 30 percent of the 2000-9 average (fig. 14E). However, the Big Blue River also had the smallest average 2000-9 simulated base flow as compared with the other major rivers of the Northern High Plains, and declines in the Big Blue River, driven by a dry climate in 2004 near Utica (table 4), were balanced by increases in other Big Blue River Basin streams (such as the Little Blue River and Big Sandy Creek). Therefore, the Big Blue River Basin baseline forecast stream base flow was only $32 \mathrm{ft}^{3} / \mathrm{s}$ smaller than that of 2000-9.

\section{Human Stresses Forecast}

The effects of potential human stresses on the Northern High Plains aquifer were evaluated through this study using alternative potential land cover maps A2 and B2; corresponding groundwater model forecasts are referred to herein as A2LC and B2LC. As described in more detail in the "Future Forecasts" section, the land cover for the A2LC forecast can be summarized as a substantial (23 percent) increase in irrigated agriculture, from 8.4 million acres in 2009 to 10.3 million acres in 2049, primarily through increases in irrigated corn and irrigated soybeans (table 5). Dryland agriculture remained about the same throughout this time, and grassland 
decreased by more than 3 million acres to accommodate the increase in irrigated agriculture. The land cover for the B2LC forecast can be summarized as a more moderate ( 13 percent) increase in irrigated agriculture, from 8.4 to 9.5 million acres from 2009 to 2049, again primarily through increases in irrigated corn and soybeans, accompanied by a substantial decrease in dryland agriculture, from 8.1 million acres in 2009 to 4.4 million acres in 2049 (table 5). The A2LC and B2LC forecasts used the same measured 2004 climate data as the baseline forecast.

To isolate the effect of only the land use changes on aquifer gains and losses and eliminate those caused by climate, A2LC and B2LC water budgets were compared against the baseline forecast (fig. 13C-E; table 7). The main differences of the A2LC forecast compared with the baseline were for losses to irrigation wells that increased 0.7 million acre-ft/yr (11 percent) and respondent gains from a net release from storage that increased 0.5 million acre-ft/yr (32 percent). The increased irrigation well outflow was necessary to accommodate the expanded irrigated area of 1.9 million acres for A2LC. This was a little more moderate for the more limited expansion represented in the B2LC forecast, having losses to irrigation wells that were only 0.5 million acre-ft/yr ( 8 percent) larger and gains from a net release from storage that were only 0.3 million acre-ft/yr (19 percent) larger. However, increases in the net release from storage correlate with groundwater-level declines, and groundwater levels declined more quickly for the A2LC and B2LC forecasts than for the baseline forecast. The trend of net release from storage was nearly the same from 2009 to 2049 (fig. 12), which indicates that the aquifer flows were not in balance with the stresses imposed under the $\mathrm{A} 2 \mathrm{LC}$ and B2LC forecasts. A2LC and B2LC losses to stream base flow, and losses to evapotranspiration, were 0.1 million acre- $\mathrm{ft} / \mathrm{yr}$ smaller than for the baseline forecast. To restate, for A2LC, a 0.7 million acre-ft/yr increase in losses to irrigation wells above that of the baseline forecast was balanced by an increase in the net release from storage of 0.5 million acre-ft/ $\mathrm{yr}$ and decreases of 0.1 million acre- $\mathrm{ft} / \mathrm{yr}$ each in evapotranspiration and stream base flow. As a result of these changes, the amount of groundwater in storage at the end of the A2LC forecast was 22 million acre-ft ( 0.9 percent) less than that of the baseline forecast. B2LC forecast declines were smaller, and the B2LC forecast had 13 million acre-ft ( 0.5 percent) less groundwater in storage than that of the baseline forecast.

The proportion of stresses in individual basins for the A2LC and B2LC forecasts was about the same as in the baseline forecast. In every basin, B2LC losses to irrigation wells were larger than for the baseline forecast, and $\mathrm{A} 2 \mathrm{LC}$ losses to irrigation wells were more than for B2LC (fig. 13C-E). Basins with the most irrigated lands (fig. 5) had the largest increases in losses to irrigation wells relative to the baseline forecast; in descending order, the Republican River Basin, the Elkhorn River Basin, and the Big Blue River Basin. These same basins, in the same order, had the largest corresponding increase in gains from a net release from storage corresponding to water level declines.
Differences in the A2LC base flow for the Big Blue River near Crete, Nebr. (USGS streamgage 06881000; fig. 14E), from the aquifer loss to streams of the Big Blue River Basin, indicated how much nontributary streamflow was in the basin. Specifically, A2LC base flow for the Big Blue River near Crete was only about $4 \mathrm{ft}^{3} / \mathrm{s}$ and was $32 \mathrm{ft}^{3} / \mathrm{s}$ smaller than that of the baseline forecast; however, A2LC loss to streams in the Big Blue River Basin was $164 \mathrm{ft}^{3} / \mathrm{s}$ (fig. 13D), about $49 \mathrm{ft}^{3} / \mathrm{s}$ smaller than the baseline. Therefore, most of the decrease in base flow in the Big Blue River Basin was for the Big Blue River upstream from Crete, Nebr., and other streams in the basin (the Little Blue River and Big Sandy Creek) had A2LC base flows that were more similar to those of the baseline forecast. Further, the precipitation near Utica, Nebr. (in the Big Blue River Basin), was a more important factor causing base flow declines for the Big Blue River upstream from Crete, Nebr., but the precipitation was not less everywhere in the Big Blue River Basin. In contrast, simulated 2000-9 base flow for the Republican River near Hardy, Nebr. (USGS streamgage 06853500; fig. 14D), was about the same size as the Big Blue River but declined less in the baseline, A2LC, and B2LC forecasts, probably because the 2004 climate used for all three forecasts was closer to average across the Republican River Basin.

\section{Environmental Stresses Forecast}

The effects of potential environmental stresses on the Northern High Plains aquifer were evaluated through this study using alternative future climate data that are referred to herein as GFDL and MRI. As described in more detail in the "Data Used to Forecast Future Conditions" section, the average 2009-49 GFDL climate data can be summarized as warmer and slightly wetter conditions than $2000-9$ and the baseline forecast, whereas 2009-49 MRI climate data indicated slightly wetter and cooler conditions than 2000-9 (table 6). The GFDL and MRI forecasts indicated a redistribution of precipitation from the spring to the summer as compared to the baseline forecast. The GFDL and MRI forecasts used the same land cover data as the baseline forecast (that of 2009). It should further be noted that because the SWB model used growing degree days to calculate crop-water demand, any temporal change in irrigation withdrawals caused by temperature differences would have been automatically adjusted by that model. However, forecast results in this report are presented on decadal or longer time scales and would probably not reveal temperature-based irrigation onset differences that were on the scale of days to weeks.

To isolate the effect of only climatic changes and eliminate those caused by land cover, GFDL and MRI water budgets were compared against the baseline forecast (fig. 11C, table 7). The largest difference was in gains of recharge from precipitation, which were 1.4 million acre-ft/yr (12 percent) smaller for GFDL, and 1.7 million acre-ft/yr (15 percent) smaller for MRI. This decrease was apparently caused by the retiming of precipitation from the spring to the growing season 


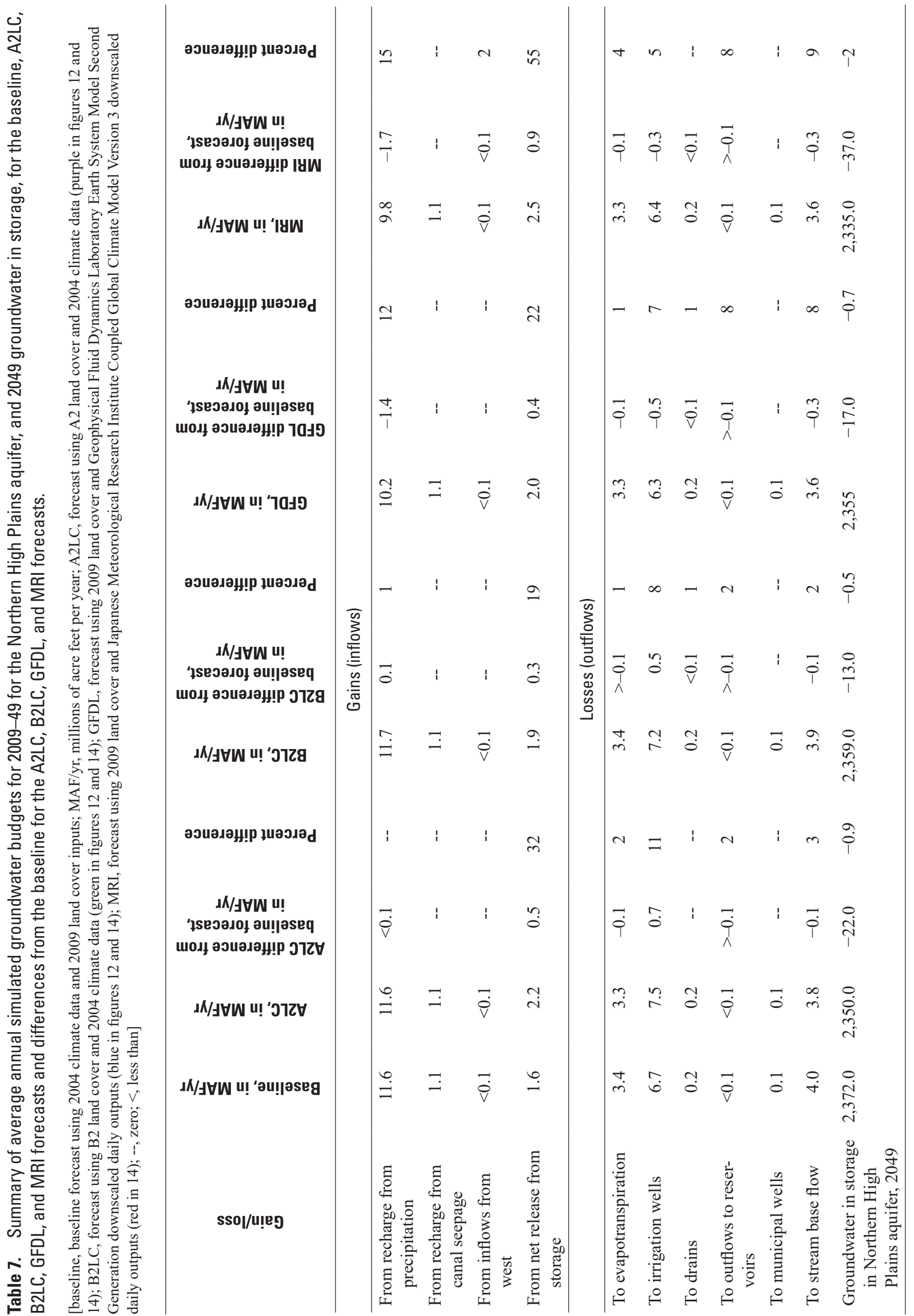


(table 6); that is, rather than precipitation falling in the spring, when vegetative growth is minimal, and resulting in recharge to the aquifer, it fell more during the summer, when crops and native vegetation are actively consuming water. Hence, GFDL and MRI losses to irrigation wells were 0.5 million acre-ft/ yr ( 7 percent) smaller and 0.3 million acre-ft/yr ( 5 percent) smaller than the baseline forecast, respectively. That is, more precipitation fell during the growing season, so less groundwater needed to be withdrawn to supply crop irrigation; however, the decrease in groundwater withdrawn for irrigation was smaller than the decrement in gains from recharge, resulting in a net negative effect for the aquifer as compared with the baseline forecast. The decrease in recharge was directly affected by the distribution of land cover, whereas native vegetation (rangeland) was far and away the dominant land cover of the Northern High Plains aquifer (fig. 5); therefore, even moderate increases in consumption of precipitation by native vegetation have the potential to have a large effect on the aquifer water budget. GFDL and MRI losses to streams were 0.3 million acre-ft/yr smaller than for the baseline forecast, probably because of the decrease in gains from recharge.

The other result of the decreased gains of recharge was that gains from a net release from storage were 0.4 million acre-ft/yr (22 percent) to 0.9 million acre- $\mathrm{ft}$ per year ( 55 percent) larger than the baseline for GFDL and MRI, respectively (fig. 11C, table 7). Again, gains from a net release from storage correlate with groundwater-level declines, and groundwater levels declined more quickly for the GFDL and MRI forecasts than for the baseline forecast; however, the trends of net release from storage were different for GFDL than for MRI (fig. 12). The decrease in the GFDL net release from storage from 2009 to 2049 indicates that the aquifer was coming to equilibrium with the GFDL forecast stresses. Conversely, the upward trend of the MRI net release from storage indicates that the rate of groundwater declines was still increasing at 2049 in the MRI forecast.

As a result of these changes, the amount of groundwater in storage at the end of the GFDL and MRI forecasts was 17 to 37 million acre-ft ( 0.5 to 2 percent) less than that of the baseline forecast (table 7). GFDL forecast declines were smaller than those of the MRI forecast, and though these datasets originated from the same global climate model, the alternate methods of downscaling the data produced different resulting effects on groundwater gains and losses. Additional details on differences in input climate data are described in the "Alternative Climate Soil-Water-Balance Models" section.

The largest difference in basin water budgets for the GFDL and MRI forecasts was gains from recharge that decreased mainly in the Loup and Republican River Basins. GFDL gains from recharge were $857 \mathrm{ft}^{3} / \mathrm{s}$ (or 21 percent) smaller than the baseline forecast in the Loup River Basin (fig. 13C, $F$, and $G$ ). Gains also decreased in the Republican River Basin, where GFDL recharge was $214 \mathrm{ft}^{3} / \mathrm{s}$ (16 percent) less than the baseline forecast and MRI recharge was $410 \mathrm{ft}^{3} / \mathrm{s}$ (36 percent) less than the baseline forecast. In these basins, the decline in recharge caused an increase in gains from a net release from storage, correlating to groundwater-level declines. These basins also had a resulting GFDL forecast decline in losses to streams, and though the rate in the Loup River Basin declined by more $\left(368 \mathrm{ft}^{3} / \mathrm{s}\right)$ than that of the Republican River Basin $\left(54 \mathrm{ft}^{3} / \mathrm{s}\right)$, the Republican River Basin had a larger relative decline (35-percent decline from baseline forecast, as opposed to 15-percent decline for the Loup River Basin). In other words, the Loup River Basin losses to streams declined more, but there was more available to lose; declines in the Republican River Basin, though smaller, represent a larger part of the baseline forecast base flow. The MRI forecast affected the Loup and Republican River Basins in the same fashion as the GFDL forecast, but to a larger extent; therefore, even though the different downscaling methods used to produce the GFDL and MRI climate data produced a different magnitude of recharge, they did not produce a different distribution of recharge.

One other difference between the baseline forecast and the GFDL or MRI forecasts was that losses to irrigation wells were smaller in the Big Blue River Basin than for the baseline forecast (by $382 \mathrm{ft}^{3} / \mathrm{s}$ for GFDL and by $308 \mathrm{ft}^{3} / \mathrm{s}$ for MRI; fig. $13 C, F$, and $G$ ). Losses were also smaller in the Elkhorn River Basin, where the losses to irrigation wells were $157 \mathrm{ft}^{3} / \mathrm{s}$ smaller for GFDL and $141 \mathrm{ft}^{3} / \mathrm{s}$ smaller for MRI. This indicates that the GFDL and MRI forecasts that produced more growing season precipitation did so mainly in the Big Blue River and Elkhorn River Basins. Conversely, GFDL losses to irrigation wells were $105 \mathrm{ft}^{3} / \mathrm{s}$ larger than the baseline for the Niobrara River Basin and $68 \mathrm{ft}^{3} / \mathrm{s}$ larger than the baseline for the Republican River Basin. Increases in losses to irrigation wells are likely correlated with increased temperatures because growing season precipitation increased overall (table 6).

The GFDL stream base flows were smaller than those of the baseline forecast, except for the Elkhorn River, and MRI base flows were smaller than those of GFDL (fig. 14A-E). The GFDL 2040-49 base flow for the Elkhorn River at Waterloo, Nebr. (USGS streamgage 06800500), was about $100 \mathrm{ft}^{3} / \mathrm{s}$ larger than for the baseline forecast. Because this was much larger than the increase in the GFDL forecast base flow for the Elkhorn River Basin, and most of the streams in that basin are tributary to the selected streamgage location, the difference was probably caused by the different period being averaged (last 10 years of the forecast as opposed to 2009-49). In other words, the flow of those last 10 years was larger than the average of the forecast period. Similarly, the largest decrease was for the Loup River at Columbus, Nebr. (USGS streamgage 06794500), where 2040-49 base flows were $300 \mathrm{ft}^{3} / \mathrm{s}$ (GFDL) or $500 \mathrm{ft}^{3} / \mathrm{s}$ (MRI) smaller than those of the baseline forecast; however, the forecast (2009-49) Loup River Basin flows declined by $366-368 \mathrm{ft}^{3} / \mathrm{s}$. The difference indicates that the GFDL and MRI forecasts were biased differently from 2040-49; therefore, different climate downscaling methods also produced different timing of recharge at a decadal time scale. 


\section{Resource Monitoring and Potential Improvements}

This section of the report describes the importance of continuing existing data collection efforts, provides context for uses of such data, and describes an evaluation of the variance of simulated groundwater levels to indicate where new groundwater-level monitoring may provide the most benefit. This section also describes additional data that could be collected to benefit future resource monitoring.

\section{Importance of Continuing Ongoing Data Collection Program}

Streamflow and groundwater-level data provide fundamental data describing water availability and will continue to be primary sources of model calibration data; therefore, these data are critical to the success of future modeling efforts used to evaluate groundwater availability. Collection of additional such data at more locations, or in some cases higher frequency such as monthly or seasonal rather than annual, may further reduce model uncertainty; for example, only 91 streamgages had data within the calibration period of this model, or about 1 streamgage for every $1,100 \mathrm{mi}^{2}$ if they were evenly spaced across the aquifer. Adding new streamgages for the largest ungaged tributaries of currently gaged streams could provide valuable data informing model calibration and surface-water interactions with groundwater and provide additional spatial context for existing streamgage data. In addition, groundwater quality and tracer data could be collected to determine pathways and timescales of environmental processes (Cook and Böhlke, 2000). Pathways and travel times could be simulated with the groundwater-flow model using particle tracking, such as MODPATH (Pollock, 2016), and compared to results of tracer sampling to further improve the model.

In addition, as of 2009, in some areas, considerable distance exists between test holes used to define thickness and character of the Northern High Plains aquifer (Houston and others, 2013). Aquifer property data directly affect simulations of groundwater flow and related uncertainty; therefore collection of additional geologic data describing aquifer thickness and other properties will directly benefit future groundwater availability studies and probably reduce simulation uncertainty. In addition, from 2010 to present (2019), considerable effort has been put into airborne resistivity data collection and, in some cases, these data have been used to improve the understanding of aquifer characteristics (Hobza and others, 2014). The earliest parts of airborne resistivity data from Abraham and others (2012) helped revise the current base of aquifer map (Peterson and Traylor, 2016); however, the rest of the airborne resistivity data were not available in time for this study and could be used to refine aquifer properties and surfaces for the Northern High Plains and other future groundwater models. Incorporation of additional geologic data may improve model calibration and reduce model uncertainty.

\section{Potential New Groundwater-Level Monitoring Locations}

The simulation described in this report can be used as a tool to evaluate the benefit of collecting additional physical or hydrologic data. As an example, an analysis was completed using the simulation to evaluate groundwater-level data. Because of the large size of the Northern High Plains aquifer, and the relative sparsity of measurements in some parts of the area (fig. 8), new groundwater-level monitoring could be done at many potential locations. Given that resources are not sufficient to measure local water levels uniformly throughout the aquifer, some relative prioritization could help indicate priority areas for monitoring. Model simulations of future conditions indicated areas where one would expect the largest changes in groundwater levels, and that information can be used to guide future data collection efforts to monitor for these potential changes; therefore, the standard deviation of simulated seasonal groundwater levels at 2,462 selected locations (fig. 15) was used as an indication of variability in future simulations that was not informed by existing observation data. As described in the "Observation Network Analysis" section, 2009-49 standard deviations were calculated from seasonal simulated water levels that were retrieved from outputs of the five future forecasts described in this report (baseline, A2LC, B2LC, GFDL, and MRI). The threshold of $5 \mathrm{ft}$ was selected because it approximated the 75th percentile of the standard deviations; that is, 75 percent of the standard deviations were less than $5 \mathrm{ft}$, whereas only 25 percent were larger.

The largest standard deviations seemed to be spatially biased, generally along the drainage divide between the South Platte River and the Republican River Basin, in southwest Nebraska, close to the northeast corner of Colorado (fig. 15). Several other locations with standard deviations larger than $20 \mathrm{ft}$ are scattered about the area but most were not close to simulated streams because streams moderate groundwater-level responses to changing hydrologic conditions. Locations with standard deviations from 5 to $20 \mathrm{ft}$ were commonly closer to drainage divides between simulated streams in the area. Near the downstream end of the South, Middle, and North Loup Rivers, the standard deviation of water levels was larger than $5 \mathrm{ft}$ for nearly every location evaluated, indicating more groundwater-level variability across the forecast results. It must be noted that these results are strictly subject to the construction and calibration of the groundwater model and the range of conditions used in the forecasting procedure (five forecasts, as described in the "Future Forecasts" section). Sampling of variability from other forecasts, alterations of the model construction or calibration, or other methods of network analysis could produce different results. 


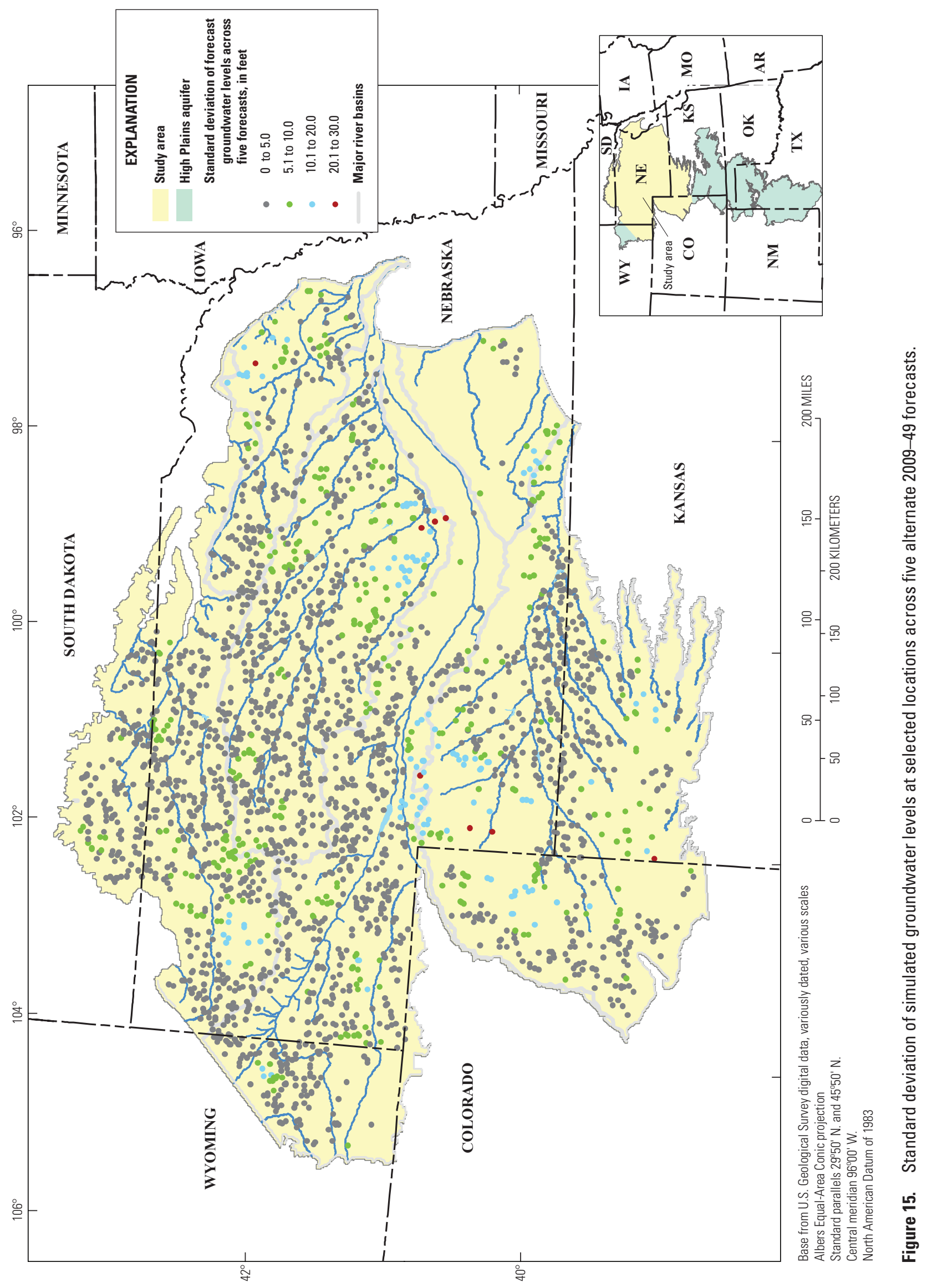




\section{Resource Monitoring Improvements}

Groundwater withdrawals for irrigation are the single largest anthropogenic effect and largest outflow component of the groundwater-flow system of the Northern High Plains aquifer, but insufficient withdrawal data have been collected to precisely characterize the amount and timing of the withdrawals. In 2009, groundwater withdrawals for irrigation in the Northern High Plains aquifer were measured only in a few areas and for a small number of seasons. The sparse amount of data represented only a fraction of a percentage of the groundwater withdrawals in the study area, and the few data that did exist may not represent groundwater withdrawal rates well at the scale of the aquifer. These issues preclude the use of existing groundwater withdrawal data for calibration or verification of groundwater withdrawal estimates produced with the SWB model in this study, though the SWB-produced estimates were within a similar range to average annual precipitation minus crop-water use. The SWB model used in this study is described in more detail in the "Future Forecasts" section, as well as in the "Data Used to Forecast Future Conditions" section, and in Peterson and others (2016a). It is assumed that the SWB model correctly represented soil-zone processes and that it was sufficiently calibrated by adjustment of the SWB recharge during calibration of the groundwater-flow model (Peterson and others, 2016a). However, if many more groundwater withdrawal data had existed, they could have been used as an initial calibration step on the SWB model outputs before input to the groundwater-flow model. By 2016, groundwater withdrawal meters had been installed in more locations across the area, yet additional compilation and review would be required to indicate if sufficient data have been collected to relate to aquifer-scale groundwater withdrawals, or if data have been collected over enough time to sample the normal range of climatic variability. In addition to the groundwater withdrawal data, ancillary related data, such as irrigation application methods and crops grown at each groundwater withdrawal site, would provide needed context to improve estimated groundwater withdrawals. Groundwater withdrawals for irrigation are the largest outflow component of the groundwater system; therefore, reduction in uncertainty in groundwater withdrawal data and estimates thereof should lead directly to reductions in uncertainty in groundwater model results and forecasts.

\section{Challenges for Evaluation of Groundwater Availability}

The model and dependent analyses described in this report that were used to analyze groundwater availability of the Northern High Plains aquifer are deemed adequate in that the calibration results indicated agreement between calibration targets and simulated equivalents and, as such, that the model correctly reproduced regional patterns of groundwater levels and flow and interaction with other features, such as groundwater discharge to streams. Several assumptions and limitations specific to the model developed for this study were described in Peterson and others (2016a). In general, although the model is considered accurate at a regional scale, it is not suitable for use in evaluating local-scale problems, nor for periods less than a few months. Readers who are interested in more local-scale analysis could use the data and results of this study as a starting point for additional refinement.

In addition, as noted in the "Resource Monitoring and Potential Improvements" section, many additional data could be collected that would improve the understanding of water availability in the Northern High Plains aquifer and would bolster the data used to calibrate the groundwater models developed as part of this study and other groundwater models. Such data include but are not limited to irrigation withdrawal data, maps describing irrigation application practices (such as pivot, sprinkler, or high-efficiency sprinkler), hydrologic data such as groundwater levels or streamflows at additional locations or increased frequency, or physical data describing aquifer properties or properties affecting interflows between the aquifer and related features.

In addition to assumptions and limitations of the models, some difficulties arose that were specific to development of a regional model, such as when attempting to simulate a principal aquifer. For the Northern High Plains aquifer simulations, problems arose for input file processing, file sharing, and communication. Original Python programs were written to handle the complexity of incorporating model parameters and adjustments to recharge or other model inputs that varied spatially and temporally. In addition, most commercially available graphical user interfaces cannot handle the large amounts of data such as were used for calibration of this model (Peterson and others, 2016a). Therefore, postprocessing was handled through original programs written in Python (Python Software Foundation, 2017), wherein summary statistics and graphical representations of model calibration were written into a commonly available file format (Adobe Portable Document Format) for review. The programs generate hundreds of plots or other summary statistics and metrics in seconds, much faster than if the outputs were postprocessed manually using spreadsheet or other user-driven processes. Readers planning other efforts with large amounts of data could benefit from similar approaches.

Readers are cautioned that future forecast base flows and groundwater budgets included in the analysis described in this report are not comprehensive and may not be the average nor span the range of effects caused by potential future climate or land cover changes. These forecasts are provided as examples of how the groundwater-flow model can be used as a tool to evaluate aquifer and stream base flow responses to potential future conditions. Alteration of input data, such as the selection of a different year from 2004 to provide average climate data inputs for three of the forecasts, likely would generate different results. For example, a large suite of downscaled global climate model data could be evaluated through the SWB model and groundwater-flow model to determine if the various 
versions have a central tendency of effects on groundwater and related flows, or to reveal the range of variation caused by the suite of forecasts. For the two environmental stresses forecasts provided in this report, no context is available to characterize how these particular forecasts might be similar or different from forecasts using other climate data.

\section{References Cited}

Abraham, J.D., Cannia, J.C., Bedrosian, P.A., Johnson, M.R., Ball, L.B., and Sibray, S.S., 2012, Airborne electromagnetic mapping of the base of aquifer in areas of western Nebraska: U.S. Geological Survey Scientific Investigations Report 2011-5219, 38 p. [Also available at https://doi.org/10.3133/sir20115219.]

Allen, R.G., Pereira, L.S., Raes, D., and Smith, M., 1998, Crop evapotranspiration - Guidelines for computing crop water requirements: Rome, Food and Agriculture Organization of the United Nations, FAO Drainage and Irrigation Paper 56, $300 \mathrm{p}$.

Autobee, R., 1996, North Platte Project: Bureau of Reclamation, 40 p., accessed January 8, 2018, at https://www.usbr.gov/projects/pdf.php?id=145.

Bartos, T.T., Diehl, S.F., Hallberg, L.L., and Webster, D.M., 2014, Geologic and hydrogeologic characteristics of the Ogallala Formation and White River Group, Belvoir Ranch near Cheyenne, Laramie County, Wyoming: U.S. Geological Survey Scientific Investigations Report 20135242, 100 p. [Also available at https://doi.org/10.3133/ sir20135242.]

Bureau of Reclamation, 2013, Downscaled CMIP3 and CMIP5 climate and hydrology projections-Release of downscaled CMIP5 climate projections, comparison with preceding information, and summary of user needs: Denver, Colo., Bureau of Reclamation, Technical Services Center, $47 \mathrm{p}$.

Cannia, J.C., Woodward, D., and Cast, L.D., 2006, Cooperative Hydrology Study COHYST hydrostratigraphic units and aquifer characterization report: Lincoln, Nebraska Department of Natural Resources, 96 p., accessed August 22, 2011, at https://digitalcommons.unl.edu/cgi/ viewcontent.cgi? article $=1101 \&$ context=usgspubs.

Central Nebraska Public Power and Irrigation District, 2018, A brief history of the Central Nebraska Public Power and Irrigation District: Central Nebraska Public Power and Irrigation District pamphlet, 11 p., accessed January 8, 2018, at http://www.cnppid.com/wp-content/ uploads/2013/11/1history_of_central.pdf.
Condon, S.M., 2005, Geologic studies of the Platte River, south-central Nebraska and adjacent areas-Geologic maps, subsurface study, and geologic history: U.S. Geological Survey Professional Paper 1706, 63 p., 2 pls. [Also available at https://pubs.usgs.gov/pp/pp1706/.]

Condra, G.E., Reed, E.C., and Gordon, E.D., 1950, Correlation of the Pleistocene deposits of Nebraska: Nebraska Geological Survey Bulletin 15-A, 74 p.

Cook, P.G., and Böhlke, J.K., 2000, Determining timescales for groundwater flow and solute transport, chap. 1 of Cook, P.G., and Herczeg, A.L., eds., Environmental tracers in subsurface hydrology: Boston, Mass., Kluwer Academic Publishers, p. 1-30. [Also available at https://doi.org/10.1007/978-1-4615-4557-6_1.]

Diffendal, R.F., 1995, Geology of the Ogallala/High Plains regional aquifer system in Nebraska, in Diffendal, R.F., and Flowerday, C.A., eds., Geologic field trips in Nebraska and adjacent parts of Kansas and South Dakota-Parts of the 29th annual meetings of north-central and southcentral sections, Geological Society of America: Lincoln, University of Nebraska-Lincoln, Conservation and Survey Division guidebook no. 10, accessed February 10, 2011, at https:/digitalcommons.unl.edu/natrespapers/75/.

Diffendal, R., Jr., Voorhies, M.R., Voorhies, E.J., LaGarry, H.E., Timperley, C.L., and Perkins, M.E., 2008, Geologic map of the O'Neill $1^{\circ} \times 2^{\circ}$ Quadrangle, Nebraska, with configuration maps of surfaces of formations: Lincoln, University of Nebraska-Lincoln, Conservation and Survey Division, Geologic Map GMC-34, 36 p., 1 pl.

Flynn, A.T., and Stanton, J.S., 2018, Simulation of groundwater flow, 1895-2010, and effects of additional groundwater withdrawals on future stream base flow in the Elkhorn and Loup River Basins, central Nebraska — Phase three: U.S. Geological Survey Scientific Investigations Report 2018-5106, 65 p. [Also available at https://doi.org/10.3133/ sir20185106.]

Gutentag, E.D., Heimes, F.J., Krothe, N.C., Luckey, R.R., and Weeks, J.B., 1984, Geohydrology of the High Plains aquifer in parts of Colorado, Kansas, Nebraska, New Mexico, Oklahoma, South Dakota, Texas, and Wyoming: U.S. Geological Survey Professional Paper 1400-B, 63 p. [Also available at https://doi.org/10.3133/pp1400B.]

High Plains Regional Climate Center, 2015, County level data for 1981-2010: High Plains Regional Climate Center digital data, accessed October 5, 2015, at https://hprcc.unl.edu/ datasets.php?set=CountyData. 
Hobza, C.M., Bedrosian, P.A., and Bloss, B.R., 2012, Hydrostratigraphic interpretation of test-hole and surface geophysical data, Elkhorn and Loup River Basins, Nebraska, 2008 to 2011: U.S. Geological Survey Open-File Report 2012-1227, 95 p. [Also available at https://doi.org/10.3133/ ofr20121227.]

Hobza, C.M., Abraham, J.D., Cannia, J.C., Johnson, M.R., and Sibray, S.S., 2014, Base of principal aquifer for parts of the North Platte, South Platte, and Twin Platte Natural Resources Districts, western Nebraska: U.S. Geological Survey Scientific Investigations Map 3310, 2 sheets, accessed December 3, 2019, at https://doi.org/10.3133/ $\operatorname{sim} 3310$.

Houston, N.A., Gonzales-Bradford, S.L., Flynn, A.T., Qi, S.L., Peterson, S.M., Stanton, J.S., Ryter, D.W., Sohl, T.L., and Senay, G.B., 2013, Geodatabase compilation of hydrogeologic, remote sensing, and water-budget-component data for the High Plains aquifer, 2011: U.S. Geological Survey Data Series 777, 12 p. [Also available at https://doi.org/10.3133/ ds777.]

Johnson, C.R., and Brennan, R., 1960, Geology and ground water in the Platte-Republican Rivers watershed and the Little Blue River basin above Angus, Nebraska, with a section on chemical quality of the ground water: U.S. Geological Survey Water-Supply Paper 1489, 142 p. [Also available at https://doi.org/10.3133/wsp1489.]

Lawton, D.R., 1984, Physical characteristics of the Sand Hills - Groundwater hydrogeology and stream hydrology, in The Sand Hills of Nebraska-Yesterday, today, and tomorrow: Lincoln, Proceedings of the 1984 Water Resources Seminar, Nebraska Water Resources Center, p. 44-53.

Masterson, J.P., Pope, J.P., Fienen, M.N., Monti, J., Jr., Nardi, M.R., and Finkelstein, J.S., 2016, Assessment of groundwater availability in the Northern Atlantic Coastal Plain aquifer system from Long Island, New York, to North Carolina: U.S. Geological Survey Professional Paper 1829, 76 p. [Also available at https://doi.org/10.3133/pp1829.]

Maupin, M.A., Kenny, J.F., Hutson, S.S., Lovelace, J.K., Barber, N.L., and Linsey, K.S., 2014, Estimated use of water in the United States in 2010: U.S. Geological Survey Circular 1405, 56 p. [Also available at https://doi.org/10.3133/ cir1405.]

McGuire, V.L., 2017, Water-level and recoverable water in storage changes, High Plains aquifer, predevelopment to 2015 and 2013-15: U.S. Geological Survey Scientific Investigations Report 2017-5040, 14 p., accessed December 3, 2019, at https://doi.org/10.3133/sir20175040.
Miao, X., Mason, J.A., Swinehart, J.B., Loope, D.B., Hanson, P.R., Goble, R.J., and Liu, X., 2007, A 10,000 year record of dune activity, dust storms, and severe drought in the central Great Plains: Geology, v. 35, no. 2, p. 119-122. [Also available at https://doi.org/10.1130/G23133A.1.]

Muhs, D.R., 2007, Loess deposits, origins, and properties, in Elias, S.A., ed., Encyclopedia of Quaternary Science: Amsterdam, Elsevier, p. 1405-1418. [Also available at https://doi.org/10.1016/B0-44-452747-8/00158-7.]

Muhs, D.R., and Bettis, E.A., III, 2000, Geochemical variations in Peoria Loess of western Iowa indicate paleowinds of midcontinental North America during last glaciation: Quaternary Research, v. 53, no. 1, p. 49-61. [Also available at https://doi.org/10.1006/qres.1999.2090.]

National Oceanic and Atmospheric Administration, 2010, Climate data online, weather observation station daily summaries, Asheville, N.C.: National Oceanic and Atmospheric Administration, National Centers for Environmental Information digital data, accessed April 15, 2016, at https://www.ncdc.noaa.gov/cdo-web/.

Nebraska Department of Natural Resources, 2004, Legislative Bill 962 - Order designating over-appropriated river basins, subbasins, or reaches, and describing hydrologically connected geographic area: Lincoln, Nebraska Department of Natural Resources, 5 p., accessed September 20, 2012, at https://dnr.nebraska.gov/sites/dnr. nebraska.gov/files/doc/water-planning/upper-platte/orders/ OverappropriatedOrder9-15-04.pdf.

Nebraska Department of Natural Resources, 2015, Registered groundwater wells data retrieval: Nebraska Department of Natural Resources digital data, accessed May 26, 2015, at https://nednr.nebraska.gov/dynamic/wells/Menu.aspx.

Niswonger, R.G., Panday, S., and Ibaraki, M., 2011, MODFLOW-NWT, a Newton formulation for MODFLOW-2005: U.S. Geological Survey Techniques and Methods, book 6, chap. A37, 44 p. [Also available at https://pubs.usgs.gov/tm/tm6a37/.]

Peterson, S.M., 2009, Groundwater flow model of the eastern model unit of the Nebraska Cooperative Hydrology Study (COHYST) area: Lincoln, Nebraska Department of Natural Resources, 70 p., accessed June 21, 2010, at http://cohyst.nebraska.gov/adobe/dc012EMU_ GFMR_090507.pdf.

Peterson, S.M., Flynn, A.T., and Traylor, J.P., 2016a, Groundwater-flow model of the northern High Plains aquifer in Colorado, Kansas, Nebraska, South Dakota, and Wyoming: U.S. Geological Survey Scientific Investigations Report 2016-5153, 88 p., accessed December 3, 2019, at https://doi.org/10.3133/sir20165153. 
Peterson, S.M., Flynn, A.T., and Traylor, J.P., 2016b, MODFLOW-NWT groundwater flow model used to evaluate conditions in the Northern High Plains Aquifer in Colorado, Kansas, Nebraska, South Dakota, and Wyoming: U.S. Geological Survey data release, accessed December 3, 2019, at https://doi.org/10.5066/F7JS9NKD.

Peterson, S.M., and Traylor, J.P., 2016, Base of aquifer contours for the Northern High Plains aquifer: U.S. Geological Survey data release, accessed December 3, 2019, at https://doi.org/10.5066/F7K072C9.

Peterson, S.M., Traylor, J.P., and Guira, M., 2020, MODFLOW-NWT groundwater flow model used to evaluate groundwater availability with five forecast scenarios in the Northern High Plains aquifer in Colorado, Kansas, Nebraska, South Dakota, and Wyoming: U.S. Geological Survey data release, https://doi.org/10.5066/P92UNY4F.

Pollock, D.W., 2016, User guide for MODPATH Version 7-A particle-tracking model for MODFLOW: U.S. Geological Survey Open-File Report 2016-1086, 35 p., accessed December 3, 2019, at https://doi.org/10.3133/ofr20161086.

Pye, K., 1995, The nature, origin, and accumulation of loess: Quaternary Science Reviews, v. 14, no. 7-8, p. 653-667. [Also available at https://doi.org/10.1016/02773791(95)00047-X.]

Python Software Foundation, 2017, Python language reference, version 2.7: Python Software Foundation software, accessed September 28, 2017, at https://www.python.org.

Qi, S., 2010, Digital map of aquifer boundary for the High Plains aquifer in parts of Colorado, Kansas, Nebraska, New Mexico, Oklahoma, South Dakota, Texas, and Wyoming: U.S. Geological Survey Data Series 543, 1 p. [Also available at https://doi.org/10.3133/ds543.]

Sheffield, J., Barrett, A.P., Colle, B., Fernando, D.N., Fu, R., Geil, K.L., Hu, Q., Kinter, J., Kumar, S., Langenbrunner, B., Lombardo, K., Long, L.N., Maloney, E., Mariotti, A., Meyerson, J.E., Mo, K.C., Neelin, J.D., Nigam, S., Pan, Z., Ren, T., Ruiz-Barradas, A., Serra, Y.L., Seth, A., Thibeault, J.M., Stroeve, J.C., Yang, Z., and Yin, L., 2013, North American climate in CMIP5 experiments, part I-Evaluation of historical simulations of continental and regional climatology: Journal of Climate, v. 26, no. 23, p. 9209-9245. [Also available at https://doi.org/10.1175/JCLI-D-12-00592.1.]

Soller, D.R., Packard, P.H., and Garrity, C.P., 2012, Database for USGS Map I-1970-Map showing the thickness and character of quaternary sediments in the glaciated United States east of the Rocky Mountains: U.S. Geological Survey Data Series 656. [Also available at https://doi.org/10.3133/ ds656.]
Stanton, J.S., Qi, S.L., Ryter, D.W., Falk, S.E., Houston, N.A., Peterson, S.M., Westenbroek, S.M., and Christenson, S.C., 2011, Selected approaches to estimate water-budget components of the High Plains, 1940 through 1949 and 2000 through 2009: U.S. Geological Survey Scientific Investigations Report 2011-5183, 79 p. [Also available at https://doi.org/10.3133/sir20115183.]

State Board of Irrigation, 1899, Second biennial report to the Governor of Nebraska: Lincoln, Nebr., State Board of Irrigation, $235 \mathrm{p} ., 1 \mathrm{pl}$.

Swinehart, J.B., Dreeszen, V.H., Richmond, G.M., Tipton, M.J., Bretz, R., Steece, F.V., Hallberg, G.R., and Goebel, J.E., 1994, Quaternary geologic map of the Platte River $4^{\circ} \times 6^{\circ}$ quadrangle, United States: U.S. Geological Survey Miscellaneous Investigations Series Map I-1420 (NK-14), scale 1:1,000,000. [Also available at https://pubs.usgs.gov/ imap/i-1420/nk-14/.]

Taylor, K.E., Stouffer, R.J., and Meehl, G.A., 2012, An overview of CMIP5 and the experiment design: Bulletin of the American Meteorological Society, v. 93, no. 4, p. 485-498. [Also available at https://doi.org/10.1175/ BAMS-D-11-00094.1.]

U.S. Department of Agriculture, 2019, Census publications: U.S. Department of Agriculture, Census of Agriculture Historical Archive digital data, accessed November 17, 2019, at http://agcensus.mannlib.cornell.edu/AgCensus/homepage. do.

U.S. Geological Survey, 2004, Cities and towns of the United States: U.S. Geological Survey digital data, accessed April 15, 2016, at https://nationalmap.gov/small_scale/.

U.S. Geological Survey, 2008, National Hydrography Dataset (medium resolution): U.S. Geological Survey, digital data, accessed September 10, 2008, at http://nhd.usgs.gov/index. html.

U.S. Geological Survey, 2019a, USGS water data for the Nation: U.S. Geological Survey National Water Information System database, accessed September 28, 2019, at https://doi.org/10.5066/F7P55KJN.

U.S. Geological Survey, 2019b, The National Map-New data delivery homepage, advanced viewer, lidar visualization: U.S. Geological Survey Fact Sheet 2019-3032, 2 p. [Also available at https://doi.org/10.3133/fs20193032.]

Watermolen, J., 2005, 1:2,000,000-scale hydrologic unit boundaries (ver. 2.0): U.S. Geological Survey dataset, accessed October 6, 2015, at https://water.usgs.gov/GIS/ metadata/usgswrd/XML/huc2m_v112.xml. 
Weeks, J.B., and Gutentag, E.D., 1981, Bedrock geology, altitude of base, and 1980 saturated thickness of the High Plains aquifer in parts of Colorado, Kansas, Nebraska, New Mexico, Oklahoma, South Dakota, Texas, and Wyoming: U.S. Geological Survey Hydrologic Atlas 648, 2 pls., scale $1: 2,500,000$. [Also available at https://pubs.er.usgs.gov/ publication/ha648.]
Weeks, J.B., Gutentag, E.D., Heimes, F.J., and Luckey, R.R., 1988, Summary of the High Plains Regional Aquifer-system analysis in parts of Colorado, Kansas, Nebraska, New Mexico, Oklahoma, South Dakota, Texas, and Wyoming: U.S. Geological Survey Professional Paper 1400-A, 39 p. [Also available at https://pubs.er.usgs.gov/publication/pp1400A.] 
For more information about this publication, contact:

Director, USGS Nebraska Water Science Center

5231 South 19th Street

Lincoln, NE 68512

402-328-4100

For additional information, visit: https://www.usgs.gov/centers/ ne-water

Publishing support provided by the Rolla Publishing Service Center 


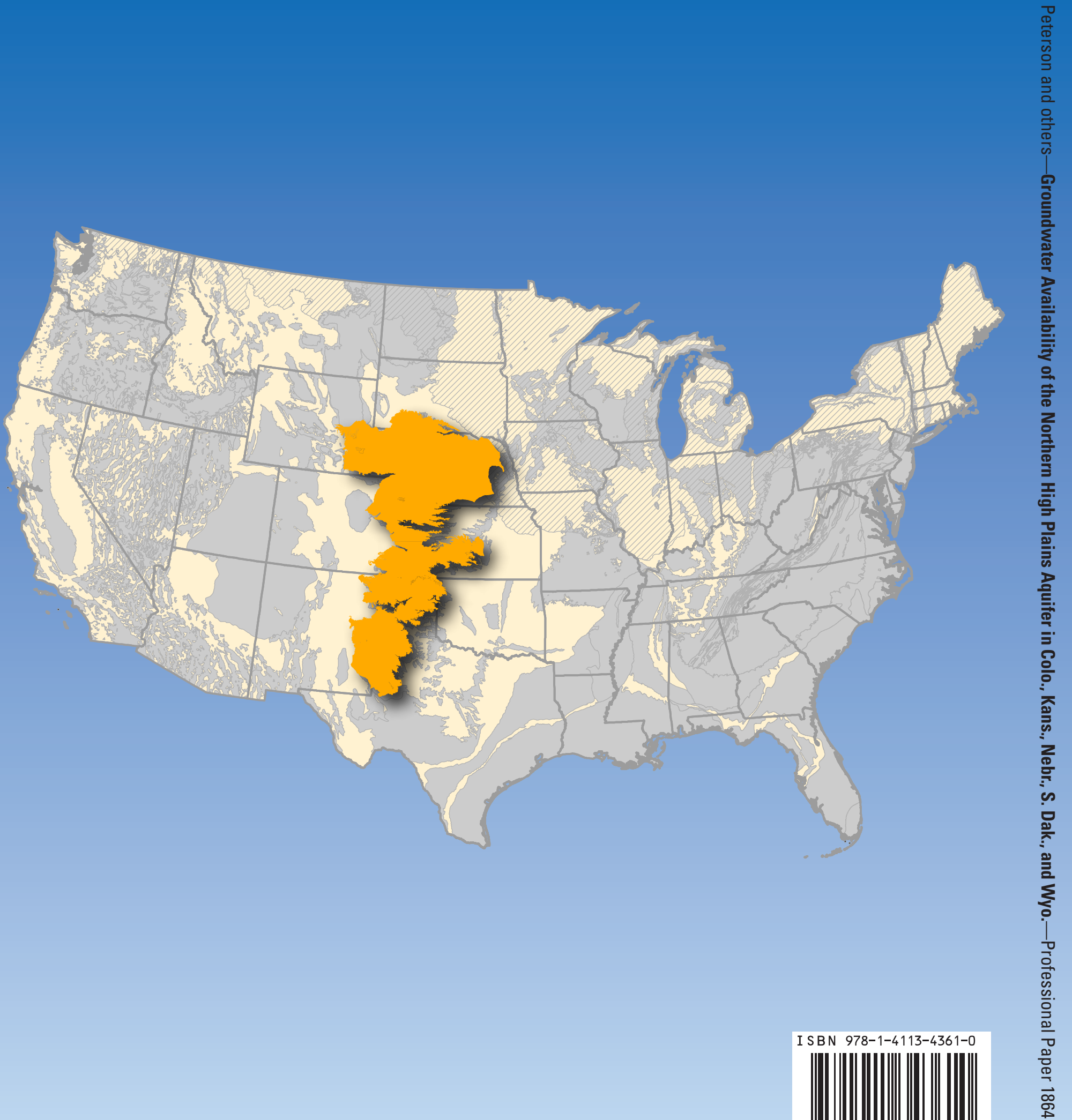